The copyright of this thesis vests in the author. No quotation from it or information derived from it is to be published without full acknowledgement of the source. The thesis is to be used for private study or noncommercial research purposes only.

Published by the University of Cape Town (UCT) in terms of the non-exclusive license granted to UCT by the author. 


\title{
PLAYFULNESS AND PRENATAL ALCOHOL EXPOSURE: A COMPARATIVE STUDY
}

\author{
Jordan Pearton \\ PRTJ0R001
}

\begin{abstract}
SUBMITTED TO THE UNIVERSITY OF CAPE TOWN
In partial fulfilment of the requirements for the degree MSc Occupational Therapy
\end{abstract}

Faculty of Health and Rehabilitation Sciences UNIVERSITY OF CAPE TOWN

Date of Submission: 24 August 2012

Supervisor: $\quad$ Associate/Professor E. Ramugondo

Department of Health and Rehabilitation Sciences, University of Cape Town

Co-Supervisor: Ms L. Cloete

Department of Health and Rehabilitation Sciences, University of Cape Town 


\section{DECLARATION}

I, Jordan Louise Pearton, hereby declare that the work on which this dissertation is based is my original work (except where acknowledgements indicate otherwise) and have used the Harvard UCT system of referencing. I declare that neither the whole work nor any part of it has been, is being, or is to be submitted for another degree in this or any other university.

I empower the university to reproduce for the purpose of research either the whole or any portion of the contents in any manner whatsoever.

Signature: Signed by candidate

Date: 24 August 2012 


\section{ACKNOWLEDGEMENTS}

A number of people have contributed to this dissertation. In particular, acknowledgements and thanks are due to the following:

- the University of Cape Town's postgraduate research centre for assisting with the funding of this research.

- to my supervisors, Associate Professor Elelwani Ramugondo and Ms Lizahn Cloete, your unfailing faith in this research and the hours of overtime you worked to assist me to meet my deadlines, has been an immense help. Thank you for the guiding me with such grace and passion for occupational therapy and the people we serve.

- to Professor Anita Bundy for assistance with the calibration and interpretation of the scores.

- to all those who have been research assistants along the way Lauren Langley; Nomonde Ngalo; Robert Hall; Dianne Steele; Matumo Ramafikeng; Pam Gretschel; Robyn Meissner; Naiema Razack; and Caraleigh Otto - I am very grateful.

- to the schools, principals and teachers who all participated in this study, thank you for the administrative assistance you provided and for the work you do for the children in your communities.

- to the participants and their parents/care-givers, thank you for letting me into your lives and for allowing me to watch you play.

- to all my friends and colleagues, thank you for always listening and encouraging me along this research journey. 
- to my family - Mom, Dad, Jethro, Hayden, Noah, and Gabriel - thank you for your patience, never-ending support and faith, and for forgiving me for play dates missed.

- to all the children l've had the honour of working with, and especially to $Z$ who inspired this research process - I pray you are playing with the angels and smiling down from heaven.

- to our Lord God, for all the blessings you have bestowed upon me and for being the light that shines so brightly in the darkest of places. 


\begin{abstract}
Background to Study: Playfulness is a child's approach to play, which remains constant over time and involves intrinsic motivation, internal control, freedom to suspend reality, and framing. Studies have revealed that children who have been prenatally exposed to alcohol (PAE) have poor social behaviour, yet none have addressed these children's playfulness or approach to social play.
\end{abstract}

Purpose of the Study: To uncover the implications of PAE on children's playfulness in order to inform interventions aimed at addressing the social functioning and well-being of these children.

Aim: To compare playfulness scores of children with PAE with their peers (a non-PAE group), and to examine any patterns of difference in the Test of Playfulness test items between the two groups.

Methods: The study was descriptive and analytical in nature. Convenience sampling was used to obtain a group of children $(\mathrm{N}=15)$ with a positive history of PAE and a reference group of children $(\mathrm{N}=15)$ who did not have a positive history of PAE, all of whom were in grade one and resided in a rural community in the Western Cape of South Africa. A fifteen minute observation of each participant engaging in free play was recorded during break-time, on their school playground. The video tapes were given to three trained and blinded raters to score using the Test of Playfulness (ToP). Rasch analysis was used to provide measure scores for each participant and these scores were then subjected to a t-test to calculate significant differences in the mean playfulness scores of each group. Non-parametric and parametric tests were used to investigate how the PAE group and non-PAE group compared on individual items of the ToP which related to social playfulness. 
Results: The PAE group had a significantly lower mean playfulness score than the non-PAE group $(p=0.02)$. When investigating differences in the individual items of the ToP, results indicated that children with PAE scored significantly lower on five of the $12(41.67 \%)$ ToP items related to social playfulness than their non-PAE counterparts. These items included: Social Play (intensity); Social Play (skill); Clowns/Jokes (extent); Clowns/Jokes (skill); and Initiates (skill). Children with PAE were found to score significantly lower on an additional two items of the ToP that were not specifically related to social play, namely Transitions (skill) and Modifies (skill).

Unexpected ratings occurred on 30 of the 870 items scored (3.45\%). These unexpected ratings were divided equally between the PAE and non-PAE participants. Twelve of the unexpected ratings occurred when participants scored lower than expected on the items 'Interacts with Objects' and 'Safety'. A further 12 of the unexpected ratings arose when participants scored higher than expected on the items 'Clowns/Jokes' and 'Mischief/Teasing'.

Conclusion: Results suggest that children with PAE are more likely to have a lowered disposition to play than their non-PAE counterparts. Children who are prenatally exposed to alcohol can therefore be considered to be more likely to experience a poorer quality of play and are more likely to struggle with some elements of social play than children not exposed to alcohol in utero. This is a new finding in the research on PAE, and is especially pertinent when considering the importance of play as a child's primary occupation and in the context of high PAE prevalence rates in certain parts of South Africa. 


\section{TABLE OF CONTENTS}

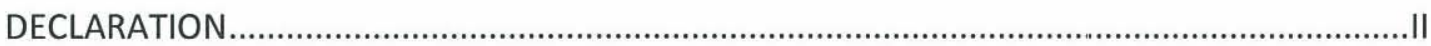

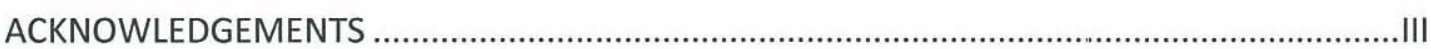

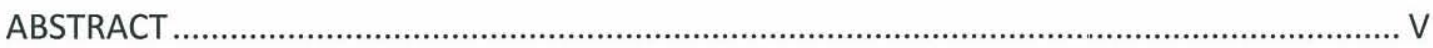

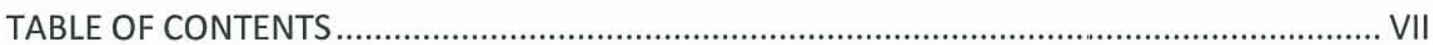

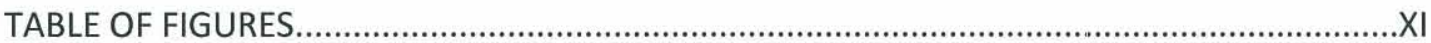

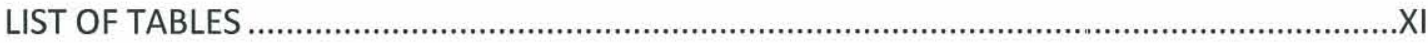

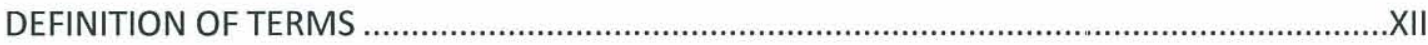

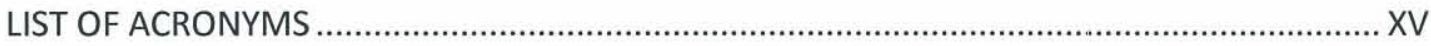

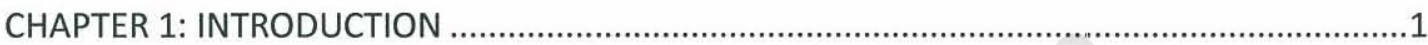

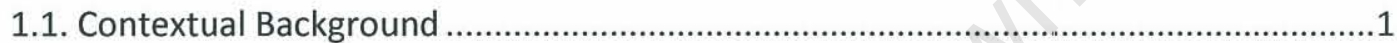

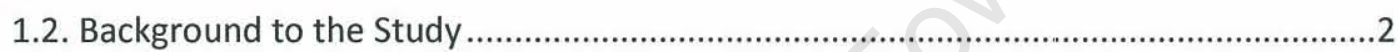

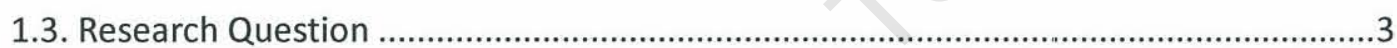

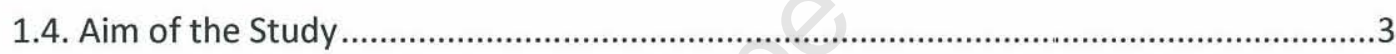

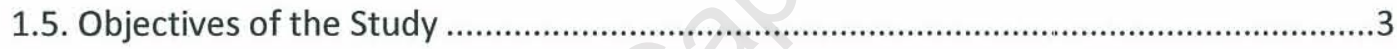

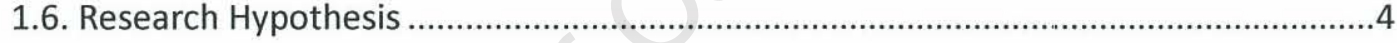

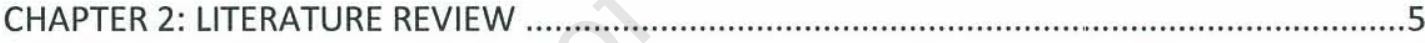

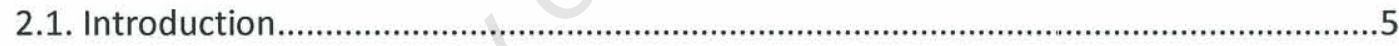

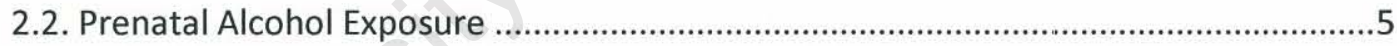

2.3. Neurobehavioural Features of Prenatal Alcohol Exposure ...........................................6

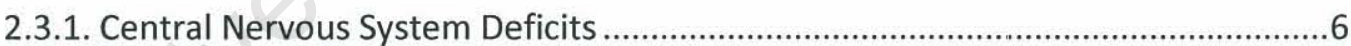

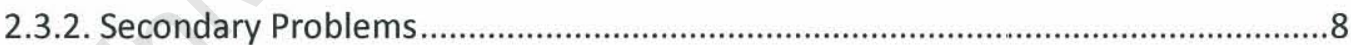

2.4. Prevalence of Prenatal Alcohol Exposure …...............................................................9

2.5. Risk Profile for Prenatal Alcohol Exposure ..................................................................10

2.6. Play and the Child with Prenatal Alcohol Exposure ....................................................11

2.6.1. Frames and Features of Play ...............................................................................11

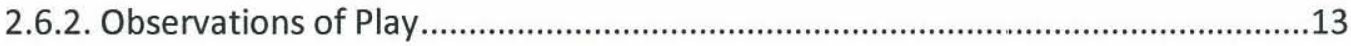

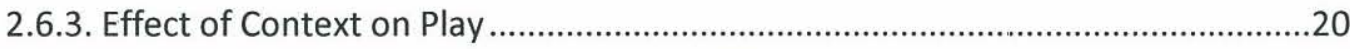

2.6.4. Effect of Prenatal Alcohol Exposure on Play ........................................................20

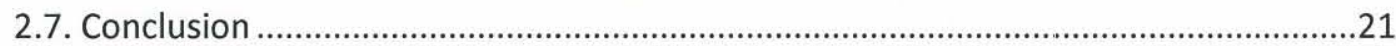

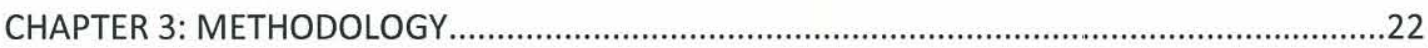

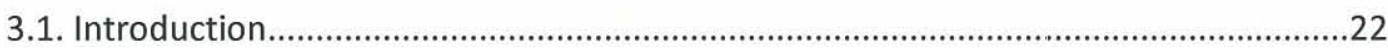

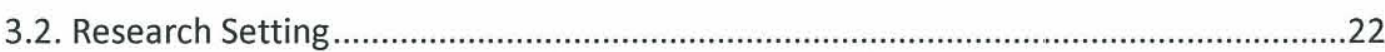




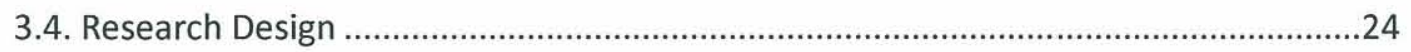

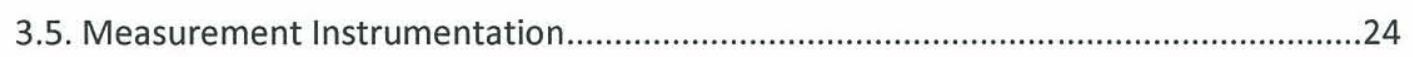

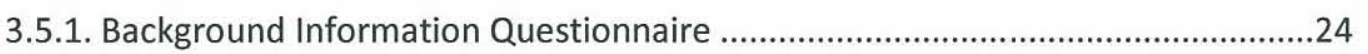

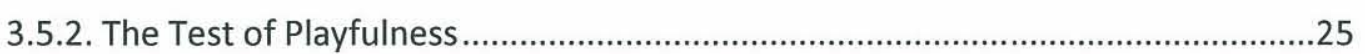

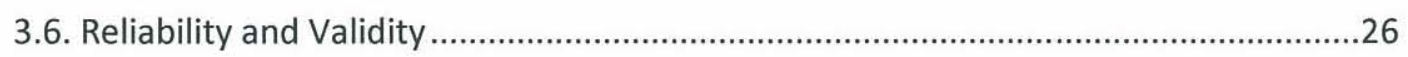

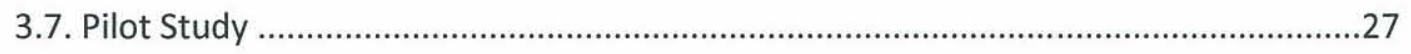

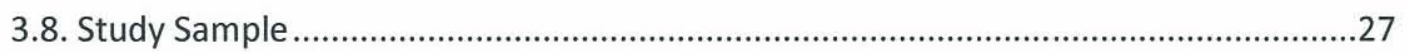

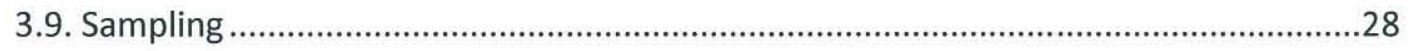

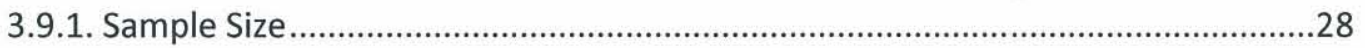

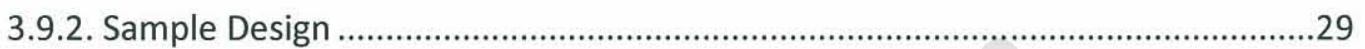

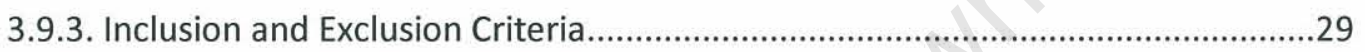

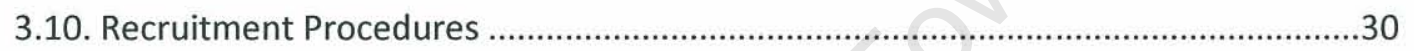

3.10.1. Contacting the Western Cape Education Department.........................................30

3.10.2. Recommendation of an Appropriate School.....................................................30

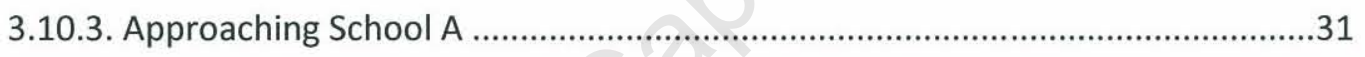

3.10.4. Contacting the Parents/Guardians of School A..................................................31

3.10.5. Interviewing the Parents/Guardians of School A ................................................31

3.10.6. Applying Inclusion/Exclusion Criteria and Allocating Participants to Groups....32

3.10.7. Informed Consent and Learner Assent ...............................................................32

3.10.8. Locating a Matched Second School....................................................................3

3.10.9. Locating a Matched Third School ..........................................................................33

3.10.10. Locating a Matched Fourth School.....................................................................33

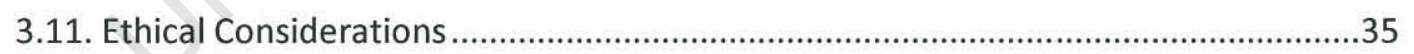

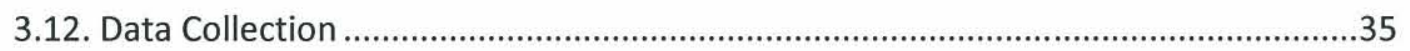

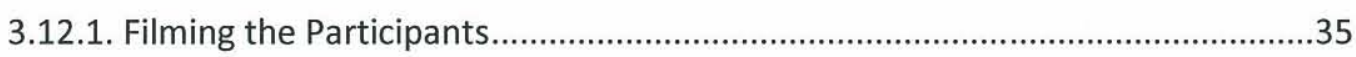

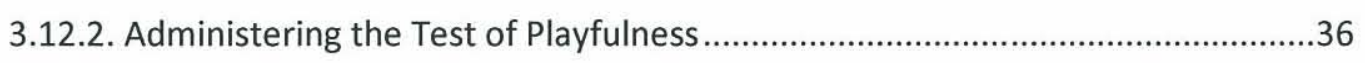

3.13. Data Management and Statistical Analysis ..................................................................36

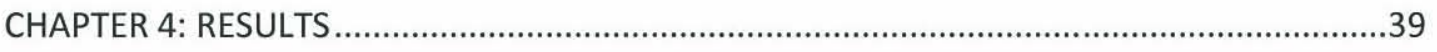

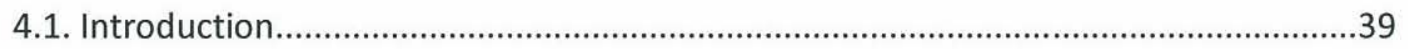

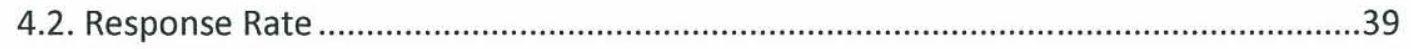

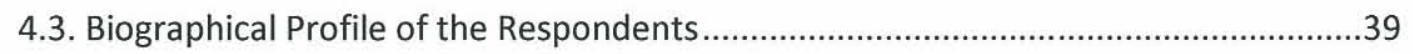

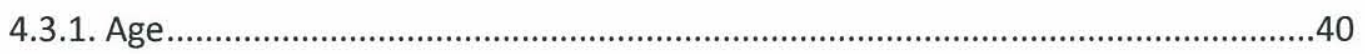

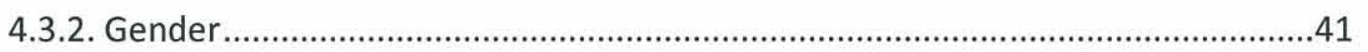


4.3.4. $1^{\text {st }}$ Year in Grade One/Repeat Year: ..................................................................42

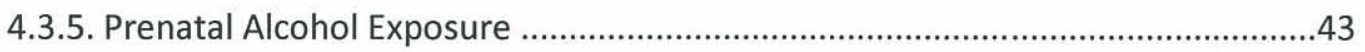

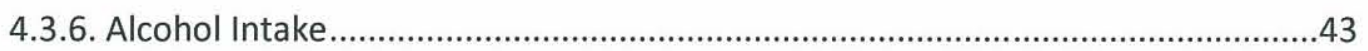

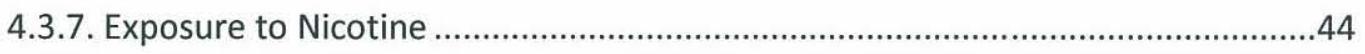

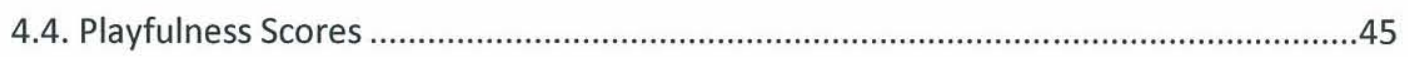

4.4.1. Group Not Exposed to Alcohol Prenatally................................................45

4.4.2. Group Exposed to Alcohol Prenatally........................................................46

4.4.3. Comparison of the non-Prenatally Exposed Group with the Prenatally Exposed Group.

4.4.4. Homogeneity of the Variances......................................................................47

4.5. Comparison of Items on the Test of Playfulness which Reflect Social Play ...............47

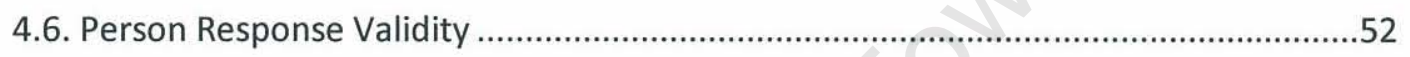

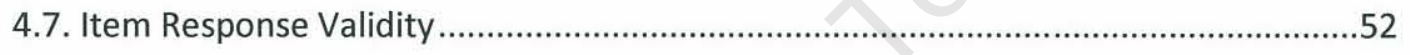

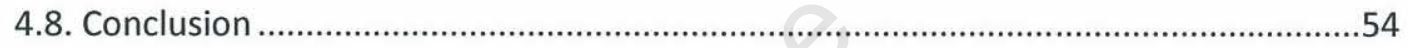

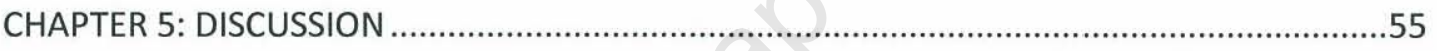

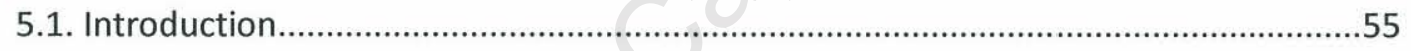

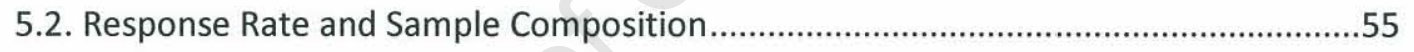

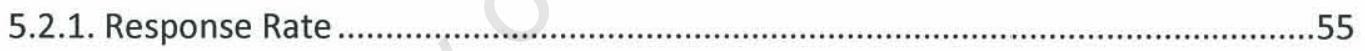

5.2.2. Comparison of Sample Composition to Existing Literature ................................56

5.3. Prenatal Alcohol Exposure and Playfulness .............................................................56

5.3.1. Impact of Poorer Playfulness on Children's Health and Well-Being ....................56

5.3.2. Prenatal Alcohol Exposure and Social Play.......................................................57

5.4. The fit of the Sample to the Existing Test of Playfulness Database ............................59

5.5. Environmental Impact on Playfulness ..................................................................61

5.6. The Role of the Occupational Therapist.............................................................62

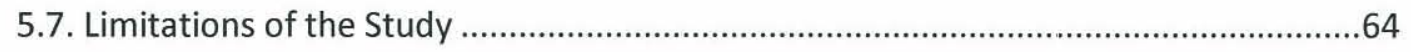

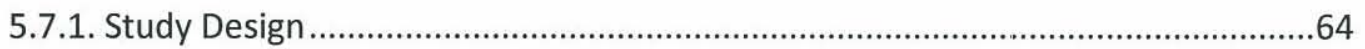

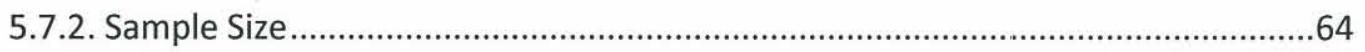

5.7.3. Context in which Play was Observed .............................................................64

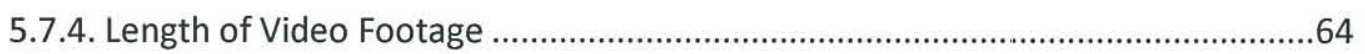

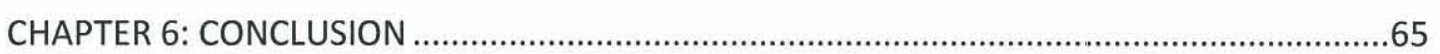

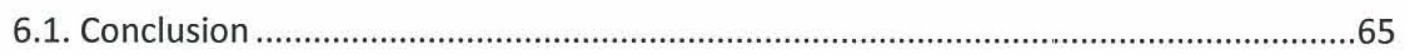

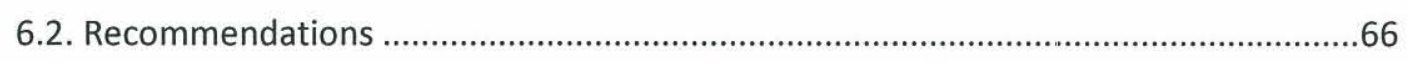




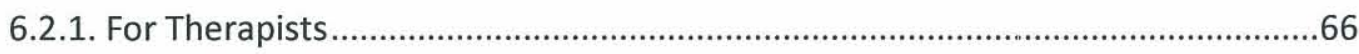

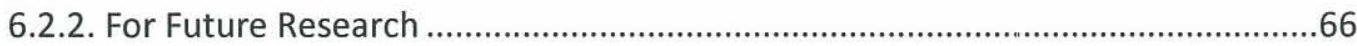

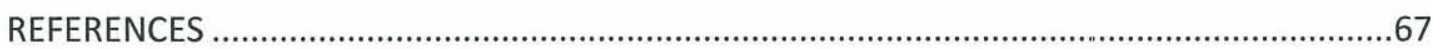

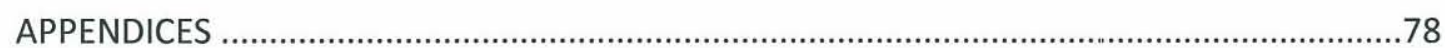

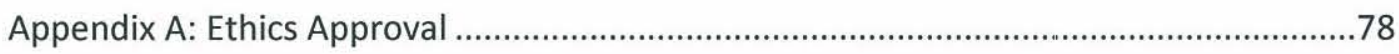

Appendix B: Letter to the Western Cape Education Department.......................................79

Appendix C: Permission from the Western Cape Education Department ..........................81

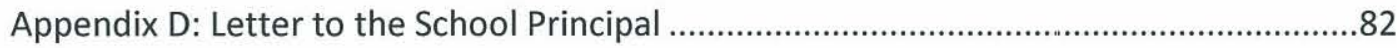

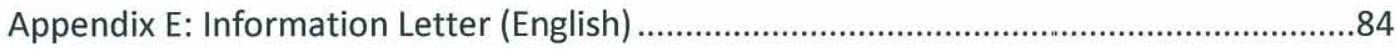

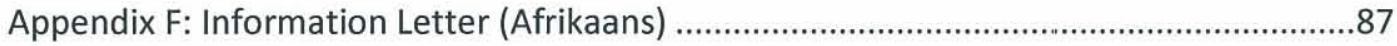

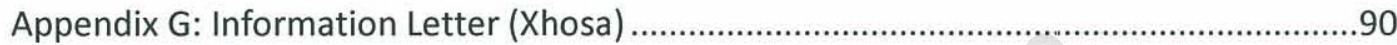

Appendix H: Consent to be contacted sheet (English) .....................................................93

Appendix I: Consent to be contacted sheet (Afrikaans) ....................................................94

Appendix J: Consent to be contacted sheet (Xhosa) ..........................................................95

Appendix K: Informed Consent Sheet (English) …..........................................................96

Appendix L: Informed Consent Sheet (Afrikaans) …….......................................................97

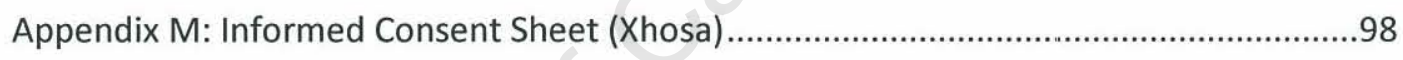

Appendix N: Participants Background Information .........................................................99

Appendix O: Definitions of Test of Playfulness (ToP) items ............................................102

Appendix P: Test of Playfulness (ToP) Protocol Sheet ....................................................104

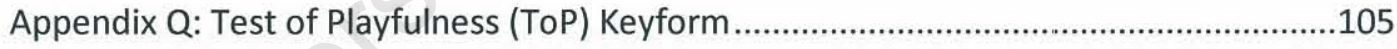

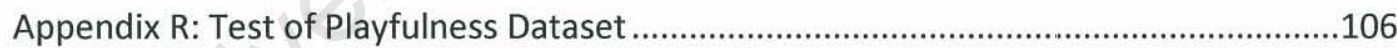

Appendix S: Summary of Notes from Interviews and Playground Observations.............107

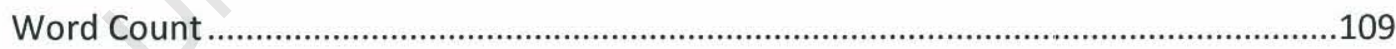




\section{TABLE OF FIGURES}

Figure 1: Summary of Recruitment Procedures . .34

Figure 2: Sample Age Distribution. 41

Figure 3: Sample Gender Distribution

Figure 4: Sample Custodianship

Figure 5: Number of Years in Grade One for Sample. .43

Figure 6: Percentage of Children in Each Group. .43

Figure 7: Parental Alcohol Intake for Sample. . .44

Figure 8: Nicotine Exposure of Sample. .45

Figure 9: Distribution of Non-Prenatal Alcohol Exposed Group Measure Scores. .46

Figure 10: Distribution of Prenatal Alcohol Exposed Group Measure Scores. .46

Figure 11: Oneway Analysis of Measure Scores 47

\section{LIST OF TABLES}

Table 1: Test of Playfulness Items Related to Social Playfulness. .17

Table 2: Comparison of Biological Information Across the PAE and Reference Groups.........40

Table 3: Comparison of Playfulness Scores Between the Groups........................................45

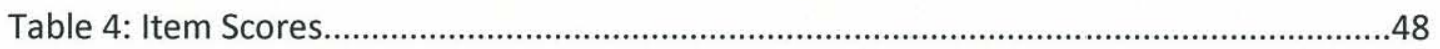

Table 5: Significant Scores Related to Social Playfulness.......................................................50

Table 6: Non-Significant Scores Related to Social Playfulness...............................................51

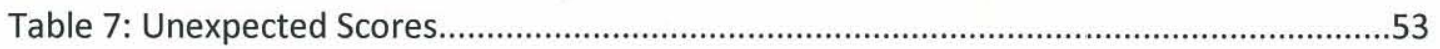




\section{DEFINITION OF TERMS}

1. Alcohol Intake

Croxford and Viljoen (1999) classify alcohol intake in units of alcohol equal to ten millilitres of absolute alcohol (AA). Ten millilitres of absolute alcohol is said to be the equivalent of $200 \mathrm{ml}$ of beer, $100 \mathrm{ml}$ wine, $30 \mathrm{ml}$ spirits and $50-60 \mathrm{ml}$ of fortified wine. Drinking can be categorised as minimal (less than five units AA/week), moderate (five to ten AA/week or binges of five to ten units per episode), or heavy (less than ten units $A A /$ week or binges of less than ten units per episode) (Croxford \& Viljoen, 1999).

2. Foetal Alcohol Spectrum Disorders (FASD)

FASD is an umbrella term which is used to describe the range of permanent conditions which result from Prenatal Alcohol Exposure (PAE) (Hoyme et al., 2004; May et al., 2008; Murthy et al., 2009).

3. Neurobehavioural Problems

The neurobehavioural problems that are associated with PAE are rooted in central nervous system deficits caused by the teratogenic effects of maternal drinking. These problems include a range of impairments in higher order cognitive and motor skills, social skills, learning, language, behaviour, and sensory processing (Aragon et al., 2008; Bohjanen, Humphrey \& Ryan, 2009; Carr, Agnihotri \& Keightley, 2010; Chandrasena, Murkherjee \& Turk, 2009; Kalberg et al. 2006; O’Leary et al., 2008; Urban et al., 2008).

4. Occupation

Occupations are the ordinary and extraordinary things that people do every day (Christiansen et al., 1995). They are central to the way that we live our lives, transacting with who we are, who we become and how we achieve our dreams and goals in life (Watson \& Fourie, 2005). Moreover, occupations are the actions and means by which people 
strive to make meaning in and of their lives, thus having a significant link to health and well-being.

5. Occupational Injustice

Occupational injustice occurs when individuals, communities, or populations are denied access to opportunities and/or resources to participate in occupations that are culturally-defined and healthpromoting (Townsend \& Wilcock, 2004). The four forms of occupational injustices are occupational alienation, occupational deprivation, occupational marginalisation, and occupational imbalance.

6. Occupational Therapy (OT)

Occupational therapy is a profession which works with "individuals, groups, organisations and communities" in order to promote their health and well-being (Watson \& Fourie, 2005:25). "OT enables people to overcome those barriers within themselves or their environment that prevent them from participating in life's occupations such as play, leisure, work and personal care" (University of Cape Town, 2011).

7. Play

Play remains an elusive concept, and experts agree that there is no one universal definition of play. Occupational therapists view play as the primary occupation of children (Parham, 2008).

8. Playfulness

Playfulness is a child's approach to play, which remains constant over time and relates to a child's ability to cope and adapt in life (Skard \& Bundy, 2008). Playfulness is a combination of intrinsic motivation, internal control, the freedom to suspend reality, and framing. 
9. Prenatal Alcohol Exposure (PAE)

PAE occurs when a mother consumes alcohol when she is pregnant, thus exposing her child to alcohol in-uterine (Rasmussen et al., 2009). 


\section{LIST OF ACRONYMS}

\begin{tabular}{|c|c|}
\hline AA & Absolute Alcohol \\
\hline ANOVA & Analysis of Variance \\
\hline AIDS & Acquired Human Immunodeficiency Virus \\
\hline FAS & Foetal Alcohol Syndrome \\
\hline FASD & Foetal Alcohol Spectrum Disorders \\
\hline IOM & Institute of Medicine \\
\hline HIV & Human Immunodeficiency Virus \\
\hline NDT & Neuro-developmental Treatment \\
\hline $\mathrm{MnSq}$ & Mean Square \\
\hline OT & Occupational Therapy \\
\hline PAE & Prenatal Alcohol Exposure \\
\hline RDP & Reconstruction and Development Programme \\
\hline SD & Standard Deviation \\
\hline Std & Standard Score \\
\hline ToP & Test of Playfulness \\
\hline WCED & Western Cape Education Department \\
\hline WC & Western Cape \\
\hline
\end{tabular}




\section{CHAPTER 1: INTRODUCTION}

\subsection{Contextual Background}

South Africa is a country marked by extreme inequalities across livelihoods, available services, and standards of living (National Planning Commission, 2011). The struggles that face today's generation of South Africans centre around high unemployment rates, a poor quality of education, inadequate infrastructure and an ailing public health system. South Africa's health system is being crippled by what is known as the quadruple burden of disease - HIV/AIDs; accidental and non-accidental injuries; infectious diseases; and the growing epidemic of diseases of lifestyle (National Planning Commission, 2011). Another health crises which is rarely discussed, is that of Foetal Alcohol Spectrum Disorders (FASD), of which South Africa has the highest recorded prevalence rates in the world (McKinstry, 2005; National Planning Commission, 2011; Rendall-Mkosi et al. 2008).

FASD is a spectrum of permanent health conditions which are caused solely by maternal alcohol consumption during pregnancy (Hoyme et al., 2004; May et al., 2008; Murthy et al., 2009). Alcohol is a known teratogen which easily crosses the placenta and can interfere with the normal growth and development of the foetus (Woods, 2002). Prenatal alcohol exposure (PAE) can lead to a range of primary and secondary disabilities, and has profound socio-economic implications for the families and communities struggling with alcohol abuse (McKinstry, 2005; Rasmussen et al., 2009).

The legacy of prenatal alcohol exposure in South Africa spans back to the 1700's when Europeans began wine farming in the Cape (McKinstry, 2005). To save costs, farmers would pay their workers a portion of their wages in alcohol. This system became known as the 'dop' systern, and resulted in 
local communities staying trapped in cycles of poverty and alcohol dependence. Although the system has long since been deemed illegal, it has proven too late to stop the development of a culture of alcoholism that prevails in some communities today (McKinstry, 2005).

Although FASD poses vast social, educational, and health challenges to South Africa (Pienaar \& Molteno, 2010), many professionals are not trained well enough to be able to identify the conditions related to prenatal alcohol exposure (May et al., 2009). As such many of the conditions associated with PAE are under-diagnosed in clinical settings (Chudley, 2.008). While some research is focused on prevention, South Africa is faced with the reality of current generations of sufferers, who deserve the opportunity to develop to their fullest potential (Pienaar \& Molteno, 2010).

\subsection{Background to the Study}

Children affected by prenatal alcohol exposure have been shown to be at risk for a wide range of neurobehavioural problems (Aragon et al., 2008; Bohjanen, Humphrey \& Ryan, 2009; Carr, Agnihotri \& Keightley, 2010; Chandrasena, Murkherjee \& Turk, 2009; Kalberg et al., 2.006; Urban et al., 2008). The majority of neurobehavioural problems relate to higher-order cognitive functions - such as the ability to reason and problem-solve - as well as behavioural problems thought to be related to poor social skills. These neurobehavioural characteristics first become noticeable between the ages of 6 to 7 years, at the same age when children begin to construct concrete friendship circles and start to play 'games with rules'. Thus far, research on the effects of the neurobehavioural problems on play as a result of prenatal alcohol exposure has been limited to the assessment of infant play and rats exposed to alcohol prenatally - both of which found that those with prenatal alcohol exposure were significantly less skilled in their ability to play than their matched counterparts (Kelly, Day \& Streissguth, 2000; Molteno et al., 2010). 
Play is the primary occupation of children (Parham, 2008). Occupational therapists view play as a means and end to a child's well-being, and are experts at assisting children with health conditions to play optimally (Bundy, et al., 2008; Parham, 2008). Playfulness is a child's disposition to play, which remains constant over time and relates to a child's ability to cope in later life (Skard \& Bundy, 2008). Playfulness is a key aspect of play to explore in children with impairments, as it focuses on the quality of a children's play and the adaptability and coping mechanisms of a child regardless of ability (Hamm, 2006). Social play is the central medium through which children learn and practice the social skills and behaviours that they will carry with them throughout life (Greene, 1997). An inability to play well with others can cause a child to develop a negative self-concept and become socially isolated (Green, 1997). Studies have revealed that children who have been prenatally exposed to alcohol have poor social behaviour (Kelly, Day \& Streissguth, 2000), yet none have addressed these children's playfulness or approach to social play.

\subsection{Research Question}

How do the levels of playfulness of children who have been prenatally exposed to alcohol compare to those who were not prenatally exposed to alcohol?

\subsection{Aim of the Study}

The aim of this study is to compare playfulness scores of children with PAE with their peers (a non-PAE group), and to examine any patterns of difference in the Test of Playfulness test items between the two groups.

\subsection{Objectives of the Study}

The primary objective is to compare the total playfulness scores (known as overall measure scores) of children with PAE with those of their non-PAE peers. 
Secondary objectives relate to comparing levels of playfulness between children with PAE and those with no reported incidence of PAE, across the following items of the Test of Playfulness (ToP) related to social play:

- engagement in social play (intensity)

- engagement in social play (skill)

- engagement in social play (extent)

- initiation of play with others (skill)

- negotiation of needs or desires during play (skill)

- sharing of toys, equipment, friends, and ideas with other children (skill)

- responding to others' cues during social play (extent)

- ability to give readily understandable cues (extent)

- clowning or joking with others (extent)

- clowning or joking with others (skill)

- entering a group already engaged in an activity (skill)

- supporting the play of others (skill)

The third objective is to determine where children with PAE fit into the typical playfulness profile as measured by the ToP.

\subsection{Research Hypothesis}

Children who have been prenatally exposed to alcohol will have lower levels of playfulness than those not prenatally exposed to alcohol. 


\section{CHAPTER 2: LITERATURE REVIEW}

\subsection{Introduction}

This review begins by introducing the existing literature on Prenatal Alcohol Exposure (PAE) and its associated conditions. The complexities of the neurobehavioural features of PAE are discussed, with specific focus on the challenges individuals with PAE experience with play and the social domain. Global and local prevalence rates are reviewed to determine the cost and scope of PAE, before risk factors for PAE are examined. An occupational perspective on play and playfulness is then outlined. The chapter concludes by drawing together the identified gaps in current literature that form the theory base for the research question.

\subsection{Prenatal Alcohol Exposure}

Prenatal Alcohol Exposure (PAE) can lead to a range of permanent conditions, which are classified under the umbrella term of Foetal Alcohol Spectrum Disorder (FASD) (Hoyme et al., 2004; May et al., 2008; Murthy et al., 2009). Foetal Alcohol Syndrome (FAS) is the most severe of these conditions and was first described by Jones and Smith in 1973 (Autti-Rumu, 2002; Murthy, et al., 2009). A diagnosis of FAS is made using the revised 1996 Institute of Medicine (IOM) criteria, which in conjunction with maternal confirmation of PAE, is based on the following three characteristics: facial dysmorphic features; growth retardation; and central nervous system deficits (Hoyme et al., 2004; Urban et al., 2008). Globally, Foetal Alcohol Syndrome (FAS) is the leading cause of intellectual impairment, as well as the most preventable cause of neurobehavioral and developmental abnormalities (Hoyme et al., 2004; Murthy et al., 2009).

To diagnose any of the conditions stemming from PAE requires a highly specialised multidisciplinary team, often lacking in the South African context (South African Medical Research Council [SAMRC], 2008). Rasmussen et al. 
(2009) report that even without a confirmed diagnosis of any of the conditions, any degree of PAE has the potential to result in long-term primary and secondary disabilities. Results from animal and clinical studies show that moderate intakes of alcohol can produce behavioural problems (Elgren et al., 2006; Kelly, Day \& Stressguth, 2000). In one such study, low levels of alcohol use during pregnancy were found to be associated with adverse behavioural outcomes in children six to seven years old (Sood et al., 2001). Studies indicate that exposure to any amount of alcohol can increase the chance of problem behaviour (Sood et al., 2001; Steinhausen et al, 2003).

\subsection{Neurobehavioural Features of Prenatal Alcohol Exposure}

The neurobehavioural problems that are associated with PAE are rooted in central nervous system deficits caused by the teratogenic effects of maternal alcohol consumption.

\subsubsection{Central Nervous System Deficits}

\section{Memory and Attention}

Children with FASD are more likely to have problems encoding (learning) new information, due to the effects of alcohol on the hippocampus and frontal cortex of the brain (Coles, 2011; Jacobson et al., 1993). This deficit decreases the brain's information processing speed and negatively affects an individual's memory.

PAE has been found to decrease attention and causes difficulties in state regulation, often leading to a comorbid diagnosis of Attention Deficit Hyperactivity Disorder (Jacobson et al., 1993; Urban et al., 2008). In addition, research indicates that individuals with PAE fixate on objects for longer periods of time, causing slower, less proficient information processing. Difficulties with attention and state regulation have been linked to secondary problems with behavioural regulation and self-control (Coles, 2011). 


\section{Visual Perception}

Individuals with PAE often have difficulties with their visual perception and visual-motor co-ordination (Coles, 2011). These central nervous system deficits are linked to further spatial processing deficiencies. Secondary problems include poor hand-writing, clumsiness, and problems with social perception.

\section{Social Cognition}

Greenbaum et al. (2009) report that individuals with PAE have difficulty with social cognition and facial emotion processing. These difficulties can lead individuals with PAE to have secondary problems with understanding social cues, decreased adaptability and flexibility, indiscriminate social behaviour, and problems communicating in social contexts (Streissguth, 1997).

\section{Motor Development}

Kalberg et al. (2006) identified that individuals with PAE are likely to have significant delays in motor development. Fine motor skills were found to be more delayed than gross motor skills. Deficiencies in fine motor skills could lead to secondary problems with handwriting, school work, and could affect an individual's self-concept.

\section{Sensory Processing}

PAE has been linked with sensory processing disorders - or the central nervous system's ability to receive, organise, and understand sensory input (Carr, Agnihotri \& Keightley, 2010). Secondary complications include maladaptive behaviours which could negatively impact on an individual's functional ability and social skills.

\section{Language}

Individuals with PAE have been found to struggle with verbal fluency and a range of language skills, such as those required for speaking, writing and the basic understanding of words (Urban et al., 2008). 
Intellectual Ability

A number of studies have reported that individuals with FASD have lower than average IQ levels, indicating a lower level of intellectual functioning (Urban et al., 2008).

\section{Complex Tasks}

Adnams et al. (2001), Aragon et al. (2008), and Carr, Agnihotri and Keightley (2010), all relay the finding that children with PAE perform considerably worse on complex cognitive tasks (such as problem-solving and higher-order reasoning and judgment) when practically implementing tasks than children who have no history of PAE.

\subsubsection{Secondary Problems}

\section{Educational and Vocational Difficulties}

Deficits in social and intellectual functioning in children with FAS often lead to difficulties in school (O'Leary et al., 2008). Although these children are reported to struggle in mainstream schools, they are not classified as intellectually disabled to the extent that they qualify for placement in schools for learners with special needs (Pienaar \& Molteno, 2010). Their functional level can therefore prevent them from benefiting from learning opportunities and they are more likely to experience failing one or more school grades. These limitations can lead to social and vocational problems (Coles, 2011).

\section{Social Behaviour and Play}

In recent years, problems relating to social behaviour have been under investigation, and it has been found that deficits in social behaviour may be a highly prevalent consequence of PAE (Carr, Agnihotri \& Keightley, 2010; O'Connor et al, 2006; McGee et al., 2009; Streissguth et al., 1991). In animal studies, rats exposed to alcohol during development have shown changes in play and parenting (Kelly, Day \& Streissguth, 2000). In human studies, deficits in social behaviour have been found across the lifespan (KullyMartens et al., 2012). Infants and young children are said to show deficits in attachment behaviour and state regulation, and children in middle childhood 
present with a variety of social behavioural problems (Kelly, Day \& Streissguth, 2000). In adulthood, PAE has been found to have links with criminality, inappropriate sexual behaviour, depression, suicide, and poor parenting skills (Kelly, Day \& Streissguth, 2000).

\section{Psychopathology}

Pienaar and Molteno's (2010) proposed the use of a self psychology perspective when to evaluate and treat psychopathology in children with FASD. They argue that disturbances in mother-infant attachment in infants with PAE may alter children with PAE's developing self-concept, increasing the risk for mental illness.

\section{The Cycle of Interdependence}

Miller and Spear (2006) describe the cycle of interdependence created when alcohol exposure during foetal development, adolescence, and adulthood are combined with negative home environments. Central nervous system deficits associated with PAE - such as cognitive deficits and impaired judgment - can make children with PAE more likely to experiment with alcohol, drugs, and risky sexual behaviour as young adolescents. Adolescent girls and women with PAE are also more likely to drink alcohol during their own pregnancies, thus reinforcing the cycle of alcohol dependence and creating generations of PAE sufferers.

\subsection{Prevalence of Prenatal Alcohol Exposure}

Researching the epidemiology and estimating the prevalence of PAE and its associated conditions has proven to be a difficult task for researchers worldwide (May et al., 2009). PAE has been described as an "invisible epidemic", as even when individuals with PAE present at clinical settings for treatment of neurobehavioural problems they are often misdiagnosed (Chudley, 2008:176; May et al., 2009). Most of the prevalence studies thus far have focused on the more severe forms of FASD, as the dysmorphology and problems with physical growth and development are more easily identifiable (May et al., 2009). Furthermore, Croxford and Viljoen (1999) point 
out that the clinical features of FASD are difficult to recognise before the age of three years and after the age of ten years, hence prevalence studies have thus far focused on grade one learners (approximately six to seven years of age).

As part of a preliminary investigation into PAE in the Western Cape of South Africa, Croxford and Viljoen (1999) interviewed 189 women from three clinics located in a rural community within the Saldanha Bay Municipality. They found that $50.8 \%$ of the sample reported PAE and $28 \%$ of these women were classified as having drunk moderate to high levels of alcohol during pregnancy. A study on prevalence levels of FAS in the United States of America estimated a national prevalence of between two to seven per 1000 (May et al., 2009). South Africa has been found to have the highest recorded prevalence of FAS in the world, estimated to be between at 68-89 per 1000 in some areas of the Western Cape of South Africa (SAMRC, 2008; McKinsrty, 2005). Even with such high prevalence estimates, there is often limited awareness amongst health professionals and the public in general about PAE, which makes it difficult to assess the needs and provide services for people with FASD (SAMRC, 2008; Chandrasena, Mukherjee \& Turk, 2008).

PAE and its associated conditions put a vast burden on society, causing great suffering to the individual and their caregivers, as well as increased educational and healthcare costs (Hoyme et al., 2004; Pienaar \& Molteno, 2010). Although no South African studies exist which have attempted to predict the cost to the government for caring for individuals with any form of FASD, a study by Lupton, Burd, and Harwood (2004) estimated that the mean annual cost of care for FAS in the United States of America in 2002 was $\$ 3.5$ billion.

\subsection{Risk Profile for Prenatal Alcohol Exposure}

Literature often presents the profile of women at risk for alcohol exposed pregnancies as residing in a rural area, being poorly educated and living in 
conditions of extreme poverty (Coggins, Timler \& Olswang, 2007; May et al., 2008; London, Suanders \& Naude, 1998; Woods, 2002). However, a study done by Astley et al. (2000) revealed that women at risk for alcohol exposed pregnancies represent a vast range of racial, socio-economic and educational backgrounds. It was found that mental health problems and being a victim of abuse are the highest risk factors for PAE (Astley et al., 2000).

Cloete (2005) bridges the gap between the above risk profiles by stating that women who are at risk for PAE are often victims of occupational injustice. South African women who live in conditions of poverty often face daily struggles with domestic violence and abuse. They have few opportunities to access health promoting occupations to cope with or escape from the cycle of abuse, and often use alcohol as a coping mechanism (Cloete, 2005; SAMRC, 2008). Poverty in the southern African context is also known to be an underlying risk factor for the development of mental health problems. Communities in which poverty is rife provide few opportunities for healthy interactions or resources that promote access to mental health services (Emsley \& Seedat, 2008). Inability to access mental health services for those in need can lead to alcohol abuse by youth and adults alike (Peterson et al., 2010). The risk factors for PAE within the South Africa context are multifaceted and thus cannot be understood without a holistic appreciation for the occupational injustices and environmental influences on maternal drinking patterns.

\subsection{Play and the Child with Prenatal Alcohol Exposure}

\subsubsection{Frames and Features of Play}

Play is a significant and primary occupation of all children (Parham, 2008). Due to its ambiguous nature, researchers and professionals have struggled through the years to find a universal description of play (Parham, 2008; Smith \& Vollstedt, 1985; Sutton-Smith, 1997). The complexity of defining play lies in the fact that it can be viewed through multiple theoretical lenses or 
frames (Chandler, 1997; Sutton-Smith, 1997). There is, however, general agreement in occupational therapy literature concerning the key features of play and these include: intrinsic motivation; process; free choice; enjoyment or pleasure; spontaneity; active engagement; and non-literality (Parham, 2008; Royeen, 1997). 'Intrinsic motivation' refers to the notion that individuals are drawn to play for the play experience itself and not because of any promise of reward (Neumann, 1971; Clark \& Miller, 1998). 'Process' emphasises the practice of doing versus the product arises from the doing (Caillois, 1961). 'Free choice' occurs when individuals engage in play when they choose to do so freely; an activity that is performed due to external expectation is thus qualified as work, not play (Caillois, 1961). 'Enjoyment or pleasure' describes the play experience as innately fun or pleasurable (Caillois, 1961). 'Spontaneity' reflects that play is self-driven, thus play has the potential to change if and when the player wishes (Rubin, Fein \& Vandenberg, 1983). 'Active engagement' defines play as requiring active participation (Sutton-Smith, 1997). Finally, 'non-literality' ensues when objects are treated like they are something else, often a prevalent feature of pretend play (Clark \& Miller, 1998).

In attempting to incorporate the multiple frames which can be used to view and define play, Sutton-Smith (1997) proposed seven rhetorics of play. These rhetorics include: play as fate; play as power; play as identity; play as frivolity; play as progress; play as imaginary; and play as self. Occupational therapists have throughout the years consistently viewed 'play as progress' and 'play as self' as the dominant lenses through which they provide assessment and treatment (Parham, 2008). Researchers operating under these two rhetorics have found that sensory-motor play in the infant years (ages nought to two) is the primary mechanism through which infants explore the world around them and learn to master their bodies (Greene, 1997). In early childhood (ages two to seven), simple and complex constructive play enables children to overcome increasingly complex developmental tasks. In middle childhood (ages seven to 11), social play and 'games with rules' come to the foreground (Bergen \& Fromberg, 2009). Social play teaches children how to become socially and emotionally competent and affords the 
opportunity for development of cognitive abilities and use of the imagination. During social play children practice their ability to wield self-control and negotiate with others (Bergen \& Fromberg, 2009). In addition, children exercise higher order cognitive skills when planning themes for pretend play, using symbols in games, and organising games with rules. Humour and the playful use of language become a skills developed and refined in social play.

Greene (1997) discusses that middle childhood represents a challenge for all children to fit in with the group and to be a fair, cooperative and contributing players. Success or failure in social play can have lasting repercussions for an individual's self esteem and self concept.

Occupational therapists who view play through the rhetorics of 'play as progress' and 'play as self' thus subscribe to the notion that play is a window into a child's soul, as well as the means by which children learn about themselves and the world around them and develop the cognitive, emotional, physical, and social skills that are necessary for life (Kuhaneck, Spitzer \& Miller, 2010). Parham (2008:18) discusses the need for an eighth rhetoric of play, that of "play as health". She reveals that this would enable occupational therapists to delve more into their underlying assumption that play is an indicator and enabler of well-being (Parham, 2008).

\subsubsection{Observations of Play}

Play is of interest to a diverse range of academic disciplines (Sutton-Smith, 1997). Psychologists, social workers, occupational therapists, philosophers, biologists, and sociologists have all been documenting and theorising about play for many years (Cornwell \& Hobbs, 1985; Parham, 2008; Sutton-Smith, 1997). Each profession uses their own unique frame of reference or rhetoric when delving into the play phenomenon (Sutton-Smith, 1997). Occupational therapists, traditionally located in the health sciences, first began to take an interest in play when they began working with children with different impairments and disabilities (Parham, 2008). Informed by the rhetoric of play as progress, occupational therapists initially used play as a means to 
understand and improve the functional outcomes of children with a broad range of disabilities (Parham, 2008).

Occupational therapists use assessments to determine a child's stage of development or level of functioning (Stagnitti, 2004). Well-known occupational therapy assessments include: the Play History Interview; the Revised Knox Preschool Play Scale; the Paediatric Interest Profiles and the Integrated Play Groups Assessment Tool (Bryze, 2008; Knox, 2008; Henry, 2008; Wolfberg, 2003). The Play History Interview uses an historical perspective and interview schedule to understand a child's development and competence in play (Bryze, 2008). The Revised Knox Preschool Play Scale is an observational assessment which provides a detailed description of typical play behaviours from birth to six years of age (Knox, 2008). The Paediatric Interest Profiles consist of three age-appropriate profiles of play and leisure interests that can be used with children and adolescents (Henry, 2008). The Integrated Play Groups Assessment Tool consists of a set of descriptive assessments which attempt to understand the social play style, developmental play patterns, communicative functions, and play preferences of children with autism (Wolberg, 2003).

Recent developments in occupational therapy have seen the profession move toward an occupational view of play, where play as an occupation is the outcome measured (Parham, 2008). Working from this premise and drawing from the works of Neumann (1971) and Bateson (1972), Bundy developed her model of playfulness (Bundy, 1997). Neumann (1971) proposed that play consists of three properties: intrinsic motivation; internal locus of control; and internal reality. 'Intrinsic motivation' has become a respected feature of play and refers to players engaging in play activities for the play experience itself as opposed to an external reward, suggesting that it is the process rather than the product of play that draws children to play (Bundy, 1997; Neumann, 1971; Rubin, Fein \& Vandenberg, 1983; Skard \& Bundy, 2008). 'Internal control' denotes that children are in control of their actions during play and refers to the ability of the child to control where they play, when they play, with whom they play, and how they play (Neumann, 
1971; Skard \& Bundy, 2008). Bundy renamed Neumann's 'internal reality' to 'freedom to suspend reality', describing it as the players' ability to choose how close to objective reality the play will be (Bundy, 1997). The abovementioned elements of playfulness are represented on a continuum: internal control ranges from internal to external; internal motivation ranges from intrinsic to extrinsic; and freedom to suspend reality ranges from free to not free (Skard \& Bundy, 2008). The summative balance of the three elements on the continuum identifies the presence of playfulness or non-playfulness (Bundy, 1997).

The forth property of playfulness incorporates Bateson's (1972) concept of 'framing'. Framing refers to the cues that are shared between players that give an understanding of they should to engage in the play activity (Bateson, 1972; Bundy, 1997).

In sum, playfulness is said to be defined as one's approach or disposition to play, and is a stable trait of an individual that remains largely constant over time (O'Brien \& Shirley, 2001; Skard \& Bundy, 2008). Royeen (1997) states that whereas play often seems to be referring to the 'doing' of play, playfulness seems to point to the very 'being' of play. Ramugondo (2005) describes how playfulness may thus be considered as an inherent human trait and links this with Royeen's (1997) notion that an individual's playfulness guides their engagement in the occupation of play. Hamm (2006) states that playfulness is a key aspect of play to explore in children with disability. This is because it does not merely focus on the performance of skills, but instead on the quality of a child's play and the adaptability and coping mechanisms of a child regardless of physical or mental ability (Hamm, 2006).

The Test of Playfulness (ToP) is an observational tool that was created to measure the playfulness of children and adolescents between the ages of six months and 18 years (Skard \& Bundy, 2008). The ToP (version four) comprises of 29 items that are rated on a four point scale. Each score reflects the extent, intensity, and skilfulness of play behaviours outlined by 
the ToP (O'Brien \& Shirley, 2001; Skard \& Bundy, 2008). The ToP was developed assess the four pillars of playfulness. Through research it was determined that each element consisted of the following observable characteristics or items of playfulness (Skard \& Bundy, 2008):

Intrinsic motivation:

- is actively engaged (extent and intensity)

- engages in activity for the sheer pleasure of it rather than primarily for the end product (extent)

- tries to overcome barriers or obstacles to persist with an activity (intensity)

- demonstrates a positive affect during play (intensity)

Internal control:

Self

- maintains a level of safety sufficient to play (extent)

- decides what to do and how to do it (extent)

- modifies activity to maintain challenge or make it more fun (skill)

- interacts with objects (intensity and skill)

- transitions from one play activity to another with ease (skill)

Shared

- negotiates with others to have needs/desires met (skill)

- engages in social play (extent, intensity, and skill)

- supports the play of others (skill)

- enters a groups already engaged in play (skill)

- initiates play with others (skill)

- shares toys, equipment, friends, ideas (skill)

Freedom to suspend reality

- engages in playful mischief or teasing (extent and skill)

- pretends to be someone else; to do something else; that an object is something else (extent and skill)

- clowns or jokes (extent and intensity)

- incorporates objects or people into play in unconventional or creative ways (extent and skill) 
Framing

- gives readily understandable cues (extent)

- responds to others cues (extent)

- is actively engaged (skill)

Although the ToP manual does not provide specific outlines as to which items are related to social play, the following 12 items in Table 1 could be seen to reflect social play (Bundy, personal communication, 2012, August 1):

Table 1: Test of Playfulness Items Related to Social Play

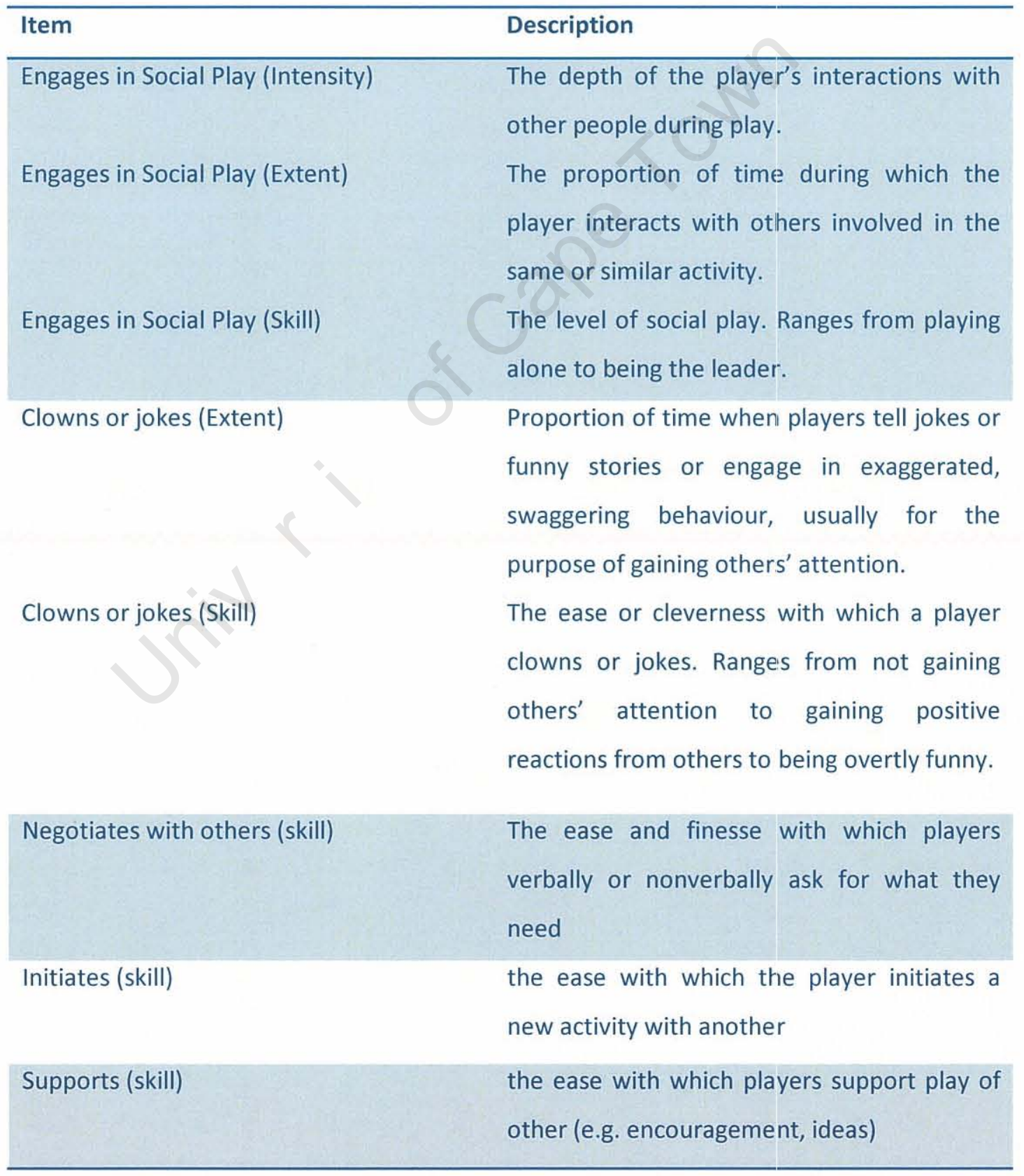




\begin{tabular}{ll}
\hline Enters a group (skill) & the ease with which the player does \\
& something to become a part of the group \\
(two or more) already engaged in an activity; & the action is not disruptive of what is going \\
on & the ease with which players allow others to \\
use toys, personal belongings, or equipment & they are using or share playmates (friends) or \\
Shares (skill) & ideas \\
the proportion of time during which players \\
act in a way to give out clear messages about \\
(extent) & how others should interact with them \\
Responds to other's cues (extent) & the proportion of time during which the child \\
& acts in accord with others' play cues
\end{tabular}

In a study examining the clinical utility of the ToP, Cameron et al. (2001) reported that participants found the ToP easy administer and score, however some found interpreting the scores to be difficult. Several participants suggested that the ToP fostered an increased awareness of the importance of the physical and social environments on children's play. One participant stated that the ToP results could be used to facilitate the social development of children.

\subsubsection{A Brief Overview of Occupational Therapy Research and the Test of} Playfulness

The ToP has been used by occupational therapists to analyse the playfulness of groups of children with different health conditions. Okimoto, Bundy, and Hanzlik (2000) conducted a study to investigate whether there were differences in playfulness scores between children with Cerebral Palsy (CP) and developmental delays, compared with normally developing children. Two occupational therapy interventions (one to improve motherchild interaction, and the other a neuro-developmental treatment [NDT] session) were given to each of the groups. Children with $\mathrm{CP}$ and children 
with developmental delays were found to score significantly poorer on overall playfulness scores than the typically developing group. Furthermore, Okimoto, Bundy, and Hanzlik (2000) discovered that the intervention to improve mother to child interaction improved significantly in the postintervention test, whilst the NDT post-test results were insignificant.

O'Brien and Shirley (2001) used the ToP to investigate whether occupational therapists could improve children's playfulness scores. They found that while playfulness remains constant over time, occupational therapy interventions can assist to improve the scores of children with special needs. A study by Hamm (2006) revealed that children with developmental disabilities were less playful than children without developmental disabilities. Muys, Rodger, and Bundy (2006) demonstrated that the ToP correlated highly with the therapist rated Children's Playfulness Scale when comparing children with Autism Spectrum Disorders.

Brentall, Bundy, and Kay (2008) examined the effect of length of observation on Test of Playfulness scores. They confirmed that 15 minutes is the appropriate amount of time required for observation of free play in indoor and/or outdoor environments.

A study by Bundy et al. (2008) found that an intervention that placed inanimate materials and objects (such as car tyres, cardboard boxes, and pieces of fabric) on a school playground improved the playfulness scores of normally developing children.

Cordier, Bundy, Hocking and Einfeld (2010) used the ToP to compare the play of children with attention deficit hyperactivity disorder by subtypes. Children with I-subtype (predominantly inattentive) found it more difficult to become engaged in play and to be playfully mischievous; however, they found social play items to be easier. The opposite was found with the HI(predominantly hyperactive-impulsive) and C-subtypes (combined). 


\subsubsection{Effect of Context on Play}

To fully understand the nature and meaning of play, play and games must be viewed in context (Greene, 1997). Ecological factors such as culture, family and gender roles directly or indirectly shape children's play experiences (Cooper, 2000). Therefore, consideration of the environment and social interactions are vital when attempting to understand play behaviours (Chandler, 1997; Greene, 1997).

Optimal play environments are said to be safe, enable creativity and use of the imagination, promote interaction with others, and encourage fun (Chandler, 1997). When environments are associated with abuse and neglect, children's play can be disrupted (Cooper, 2000). Access to play objects and safe play environments may also be severely restricted by poverty. Children who experience negative play environments are more likely to be at risk for delayed play skills, decreased playfulness, and behavioural disturbance in their play, making them more likely to experience secondary learning and social problems (Cooper, 2000).

\subsubsection{Effect of Prenatal Alcohol Exposure on Play}

Although much literature exists regarding how children play in the presence of impairment, disability or illness, the researcher found very little literature on how children with PAE or its associated conditions play. Molteno et al. (2010) used Jacobson et al.'s (1993) adapted version of the Developmental Scale of Play (Belsky \& Most, 1981) to explore the use of infant symbolic play as an early indicator of foetal alcohol-related deficits. They established that PAE had a significant effect on elicited play at the age of 13 months. In another study by Lawrence et al. (2008), it was found that ethanol exposure in rats resulted in deficits in social play. Direct observation of play has not been conducted in older children with a positive history of PAE (Kelly, Day \& Streissguth, 2000). 


\subsection{Conclusion}

A review of the literature has revealed that children affected by prenatal alcohol exposure have been shown to be at risk for a broad range of neurobehavioural problems (Aragon et al., 2008; Bohjanen \& Humphrey, 2009; Carr, Agnihotri \& Keightley, 2010; Chandrasena, Murkherjee \& Turk, 2008; Kalberg et al., 2006; Urban et al., 2008). While the neurobehavioural features of PAE become prominent between the ages six to seven years (Sood et al., 2001), research on the effects of these neurobehavioural problems on play has thus far been limited to the assessment of infant play and rats exposed to alcohol prenatally (Kelly, Day \& Streissguth, 2000; Molteno et al., 2010).

Pienaar and Molteno (2010) state that while some research is focused on the prevention of prenatal alcohol exposure, current generations of sufferers deserve the opportunity to develop to their full potential. Occupational therapists are experts at assisting children with health conditions to play optimally (Bundy, 2008), yet no occupational therapy literature has described how children with PAE play. Playfulness is a key aspect of play to explore in children with impairments, as it focuses on the quality of a children's play and the adaptability and coping mechanisms of a child regardless of ability (Hamm, 2006). 


\section{CHAPTER 3: METHODOLOGY}

\subsection{Introduction}

The literature review highlighted the need for research that describes and analyses the relationship between prenatal alcohol exposure and playfulness. This chapter begins by presenting the research setting and a suitable research design. The measurement instrumentation utilized and issues pertaining to the reliability and validity of the study are outlined. The chapter goes on to discuss the pilot study and study sample, before presenting the sampling methods. Thereafter details of the recruitment selection and data collection process are discussed in-depth. The chapter concludes by specifying the data management and statistical techniques used to analyse potential relationships between the comparison groups.

\subsection{Research Setting}

The Saldanha Bay Municipality is located 140 kilometres north of Cape Town (Saldanha Bay Municipality, 2007). The estimated population in 2010 was approximately 88566 . The municipality is mainly residential, with a population that is predominantly Coloured ${ }^{1}$. The majority of the people living in the municipality are relatively poor (Saldanha Bay Municipality, 2007).

The local economy, although historically dependent on fishing and agriculture, is said to be moving towards a focus on developing manufacturing and tourism as major areas of growth potential (Saldanha Bay Municipality, 2007). The municipality's primary limitations include: rising unemployment rates (21.4\% in 2005); increasing amounts of drug related crime; and a high disease burden. Nineteen schools fall within the municipality, with the local educator to learner ratio being estimated at 1/38

\footnotetext{
${ }^{1}$ Coloured is a term used in South Africa to refer to people of mixed-race ancestry (Oxford Dictionaries Online, 2012). It is not considered to be an offensive term in contemporary South African society.
} 
(Saldanha Bay Municipality, 2007). Results from research on early grade retention in South Africa concluded that approximately seven percent of pupils repeat grades in primary school (Department of Education, 2011). This is higher than the average level for developing countries (five percent) and is markedly higher than the average level for developed countries (less than one percent). Boys were revealed to repeat grade one more than girls (eightpoint-two percent compared to six-point-one percent), with the total number of repeaters in grade one standing at seven-point-two percent (Department of Education, 2011).

A teacher who is employed by a government primary school in the Saldahna Bay Municipality, describes the socio-economic hardships that impact the school at which she teaches (Langley, personal communication 2012, March 19). She states that the school is located in a disadvantaged community which is challenged by high levels of unemployment, drug and alcohol abuse, and single parenthood. Many of the families are said to survive on government grants. Housing varies from formal housing to government built Reconstruction and Development Programme (RDP) housing to informal shacks. The national feeding programme provides many of the children at risk for malnutrition with a daily hot meal. School fees are compulsory for those who are able to afford them, but more than half of the parents are not able to pay the annual R200 fee (Langley, personal communications 2012, March 19). A summary of the interviews conducted with the school principals and observations of the school playgrounds made by the researcher can be found in Appendix R.

\subsection{Research Methodology}

A quantitative methodology utilises numerical data to test hypotheses and determine the relationships between variables (Creswell, 2003). A quantitative approach was thus deemed appropriate to determine whether a relationship exists between playfulness and prenatal alcohol exposure. 


\subsection{Research Design}

Descriptive Analytical Research: Case-Control Design (Nonexperimental)

Descriptive analytical research is research which is often conducted in natural settings, when manipulation of the independent variable is impractical and/or unethical (Johnson, 2001). It permits researchers to describe a phenomenon at a certain point in time and to explore its characteristics, but does not enable researchers to determine a causal relationship between variables (Hicks, 2009; Johnson, 2001). A case control design allows for the comparison of a group of individuals with a pre-existing disease or condition (cases) to a matched group of individuals in whom the disease or condition is absent (controls) (Schlesselman, 1982).

The independent variable (also known as the non-manipulated or participant variable) in this study is prenatal alcohol exposure. The dependent variable in this study is the level of a child's playfulness. Children with PAE thus form part of the 'case' group whilst children with no history of PAE constitute the 'control' group.

\subsection{Measurement Instrumentation}

\subsubsection{Background Information Questionnaire}

A questionnaire (see Appendix $\mathrm{N}$ ) was designed by the researcher to obtain background information from the caregivers of potential participants. The questionnaire was modelled on an informal history-taking questionnaire the researcher and her colleague had developed during their time working with mothers of babies with PAE, prior to the onset of the current research. The questionnaire elicits information about the participants demographic information; birth history; medical history; early childhood development; and social situation. This information was used to distinguish which children met the inclusion and exclusion criteria (see 3.9.3.) as well as for inter-group comparisons on demographic information. 


\subsubsection{The Test of Playfulness}

The Test of Playfulness (ToP) is designed to assess the playfulness of children and adolescents between the ages of six months and 18 years (Skard \& Bundy, 2008). The test is designed to be used by occupational therapists who have read the Test of Playfulness manual (no further training is required for clinical use). Scores are recorded on the ToP protocol sheet (see Appendix P) after 15 minutes of free play is observed, in indoor and/or outdoor play environments that are familiar to the child.

The ToP (version four) comprises of 29 items (see Appendix O) that are rated on a four point scale and which can be scored directly or through the use of video-taping (Skard \& Bundy, 2008). Raters provide scores for each empty block on the ToP protocol sheet (See Appendix $P$ ), comprising of the 29 items. Each score reflects the extent $(0=$ rarely/never, $3=$ almost always), intensity ( $0=$ not, $3=$ highly), or skilfulness $(0=$ unskilled, $3=$ highly) of play behaviours outlined by the ToP (O'Brien \& Shirley, 2001; Skard \& Bundy, 2008). Space is provided alongside each item on the scoring sheet for the raters to comment on any behaviours or observations made (see Appendix P). Scorers are interpreted by circling the scores on the ToP Keyform (see Appendix Q) and drawing a line through the centre of the scores. The line runs through the mean measure score for that individual. Scores are interpreted by plotting the individuals mean measure score on the ToP dataset (see Appendix R) to determine whether the individual is more or less playful than the average child in the ToP dataset.

The ToP has been found to be valid across cultural groups and sexes (Skard \& Bundy, 2008). Data from the ToP research database indicates that approximately $96 \%$ of the items, $93 \%$ of the participants, and $95 \%$ of the raters have met the assumptions of the model. Thus the ToP has been found to have high interrater reliability, as well as content and construct validity when used with children with disabilities, including those with cognitive deficits (Cordier et al., 2010; Hamm, 2009; Okimoto, Bundy \& Handzik, 2000). In addition the ToP has also been proven to have moderate test-retest (inter-class correlation of 0.67 at $\mathrm{p}<0.01$ ). 


\subsection{Reliability and Validity}

This study used matching to attempt to decrease selection bias and the threat to internal validity that non-equivalent groups poses (Jackson, 2009). Stuart and Rubin (2008) described matching as a technique which researchers utilize to imitate the ideal of randomized experiments when using observational data. Attempts were made to match the groups on the following potential extraneous variables:

- gender

- grade

- community

- school

- play environment

Other measures to ensure the study's reliability and validity included the following:

- to ensure no researcher bias, three occupational therapists not involved in the research study were asked to assist with the scoring of the tapes. The therapists were all unfamiliar with the ToP and the training manual. The therapists were thus trained and their ToP scores were calibrated to ensure precise results and enable inter-rater reliability. Calibration of the scores involved each therapist being asked to watch and score eight ToP videos that were posted to the researcher by the author of the ToP. Once completed, the scores were sent to back to the author of the ToP, who ran them through the Rasch Measurement Software to determine whether the therapists conformed to the expectations of the model. These expectations were that more lenient raters are more likely to give high scores, while stricter raters are more likely to give lower scores, allowing for a five percent margin of error (Wright \& Masters, 1982). The Rasch Measurement Software calculates whether a rater is consistently more lenient or more strict and adjusts the scores to represent the 'true' score before any analysis takes place. 
- a pilot study was conducted at each school in order to give the participants time to get used to the video camera equipment before the footage was taken, thus limiting responder bias.

The literature reveals that previous studies to determine prevalence rates in South African communities have found that the participants are particularly open and honest about alcohol use during pregnancy (May et al., 2008). Thus previous studies with this population group have had high internal and external validity (May et al., 2008).

\subsection{Pilot Study}

A pilot study was conducted at each school before the participants were filmed ( $N=4)$. The pilot study involved filming one of the non-PAE children not selected for participation in the main study from each school, during a normal break-time. This was done in order to test out the feasibility of using the recording equipment in the school playgrounds and with the study sample. The pilot study also enabled the refinement of filming techniques and the data collection process, before commencing with the actual data collection. No adaptations of the ToP or the research sample used were deemed necessary.

\subsection{Study Sample}

The study sample consisted of a group of children with a positive history of PAE $(N=15)$ and a reference group of children who did not have a positive history of PAE $(\mathrm{N}=15)$. Children from both groups were all in grade one and living in a rural communities within the Saldanha Bay Municipality of the Western Cape, South Africa. Children who are in grade one are of the age in which social play comes to the foreground, as well as the age group where the neurobehavioural problems associated with PAE (social skills deficits being one of them) can be more easily observed (Croxford \& Viljoen, 1999; 
Greene, 1997; Sood et al., 2001). Thus this age group was used in order to explore how children with PAE approach social play.

Croxford and Viljoen (1991) illuminate a few differences between children at risk for prenatal alcohol exposure, and those not at risk within the Saldahna Bay Municipality and two other nearby communities. Unfortunately they did not distinguish between the demographic profiles for women who reported prenatal alcohol exposure and those with no history of prenatal alcohol exposure. Instead, they state that the majority of the women sampled $(\mathrm{N}=256)$ were classified as mixed ancestry or Cape Coloured (86.3\%). Most of the women were also single (57\%), Christian (72.8\%) and were moderately educated ( $49.2 \%$ had between 8 to 10 years of formal education) (Croxford \& Viljoen, 1991). Forty-two percent of the women reported family incomes of less than R1000/per month (Croxford \& Viljoen, 1991).

Croxford and Viljoen (1991) then went on to differentiate drinking patterns between mothers who had drunk alcohol during their pregnancies and those who did not. They found that $57.2 \%$ claimed to have no history of having consumed alcohol when pregnant, while $42.8 \%$ reported a positive history of PAE. Beer was found to be the main type of alcohol ingested (91.5\%) by women who reported PAE, and $23.7 \%$ reported a binge-drinking pattern. Thirty-six and a half percent of women reported that they had used both alcohol and tobacco when pregnant. Eighty-eight point one percent of mothers who were classified as significant drinkers during their pregnancies reported that they were aware that they had been putting their unborn children at risk by consuming alcohol during their pregnancies.

\subsection{Sampling}

\subsubsection{Sample Size}

This study used a sample size of 30 participants, 15 in the PAE group and 15 in the non-PAE group. The sample size was calculated in consultation with a 
statistician at the University of Cape Town, using mean and standard deviation scores from a previous study that explored the use of the ToP with children with and without developmental disabilities (Hamm, 2006). The sample size was calculated on a five percent power of 80 , in order to calculate statistically significant difference between the ToP scores of the PAE group and the non-PAE group.

\subsubsection{Sample Design}

Convenience sampling was used to identify the research participants. This form of non-probability sampling is used when people or objects are selected for convenience (French, 1993).

\subsubsection{Inclusion and Exclusion Criteria}

\subsubsection{Inclusion criteria for PAE group:}

- a positive history of PAE from the child's parents/caregivers

- grade one learners

- both girls and boys

- resident in communities within the Saldanha Bay Municipality

- attend primary schools matched on socio-economic status

\subsubsection{Inclusion criteria for reference group:}

- grade one learners

- both girls and boys

- resident in communities within the Saldanha Bay Municipality

- attend primary schools matched on socio-economic status

\subsubsection{Exclusion criteria for PAE group:}

- a history of, or treatment for playfulness or socio-behavioural problems from an occupational therapist, psychologist, social worker, or educator

- exposure to other drugs in-utero, except nicotine - the majority of South African mothers who consume alcohol when pregnant have also been shown to smoke nicotine prenatally (Urban et al., 2008) 
- a known comorbid disability, illness, or condition, such as developmental disorders, or Cerebral Palsy (CP) - previous studies have shown that these other disabilities or illnesses can affect children's playfulness (Hamm, 2006; Okimoto, Bundy \& Hanzik, 2000; Reid, 2004)

\subsubsection{Exclusion criteria for reference group:}

- children with positive history of PAE

- a history of, or treatment for playfulness or socio-behavioural problems from an occupational therapist, psychologist, social worker, or educator

- exposure to other drugs in-utero (except nicotine)

- a known comorbid disability, illness, or condition, such as developmental disorders or $\mathrm{CP}$

\subsection{Recruitment Procedures}

\subsubsection{Contacting the Western Cape Education Department}

Once ethical clearance was granted from the University of Cape Town's Human Research Ethics Committee (see Appendix A), the Western Cape Education Department (WCED) was asked for permission to approach a school within the Saldanha Bay Municipality (see Appendix B). Permission was granted on the $4^{\text {th }}$ January 2012 for data collection to occur between $16^{\text {th }}$ January 2012 and $28^{\text {th }}$ June 2012 (see Appendix C).

\subsubsection{Recommendation of an Appropriate School}

The WCED was asked to advise on a school that would be appropriate for inclusion in the study. A psychologist who is employed by the WCED and who works at all the government schools within the Saldahna Bay Municipality was contacted. The psychologist recommended School $\mathrm{A}^{2}$ which was an appropriate fit for the study.

\footnotetext{
${ }^{2}$ Pseudonym
} 


\subsubsection{Approaching School A}

School A was approached and a letter of information (with attached ethics

approval and approval from the WCED) was emailed to the principal of School A (see Appendix D). Thereafter, a meeting was held with the principal to discuss the feasibility of conducting the study at the school. When this was determined, permission was asked for the study to be conducted on their school playgrounds. Permission was granted and the guidance counsellor assisted by co-ordinating the handing out and collection of the information letters.

\subsubsection{Contacting the Parents/Guardians of School A}

Parents/guardians of the 219 children in the grade one classes (four Afrikaans classes and two Xhosa classes) at school A were sent information sheets (see Appendix E-G) regarding the research study and were asked for permission to be contacted telephonically (see Appendix H-J).

\subsubsection{Interviewing the Parents/Guardians of School A}

Forty-two consent to be contacted forms were received. Parents/guardian's were contacted and the objectives of the study were briefly described. An interview was conducted with the parents/guardian's who were interested in finding out more about the study and who would consider their child's participation in the study (see Appendix $\mathrm{N}$ for the background information that was asked). According to the parent/guardian's preference, the interviews were either conducted in person in a private room on the school property, or telephonically. A Xhosa translator who lectures Xhosa to undergraduate Health Science students at the University of Cape Town was hired to assist with the Xhosa interviews $(\mathrm{N}=15)$. Almost a third of the parents/guardian's who had given permission to be contacted could not be reached. Some of the numbers given by the parents were unavailable $(\mathrm{N}=8)$, while other parents $(\mathrm{N}=6)$ who had opted to conduct the interview in person did not arrive at the arranged time. 


\subsubsection{Applying Inclusion/Exclusion Criteria and Allocating Participants to Groups}

None of the Xhosa mothers whom the researcher interviewed stated that they had used any drugs or alcohol when pregnant. In total, four parents/guardian's reported a positive history of PAE, whilst 22 reported nonPAE. Three mothers revealed that they had consumed alcohol as well as smoked marijuana during their pregnancies and they were thus excluded from the sample. One guardian was unaware of the prenatal history of the child in her care and therefore could not take part in the study. Four PAE participants and four matched reference participants were chosen from School A.

\subsubsection{Informed Consent and Learner Assent}

Parents/guardians were contacted telephonically to inform them that their child qualified to partake in the study and were asked for informed consent for participation in the study (See Appendix K-M).

The University of Cape Town's Human Research Ethics Committee advises that in addition to informed consent, assent should be obtained from children in order to respect their emerging autonomy (UCT, 2009). The sensitive nature of the study and the age of the children were taken into consideration in the planning of gaining assent. The process involved informing the potential participants and their peers about the broad nature of the study in their classroom before break-time. The learners were given the opportunity to ask questions and were informed of their rights to refuse to participate and to withdraw from participating at any time. The declaration of Helsinki (World Medical Association, 2008) states that if assent cannot be gained in writing (as was determined in this study), non-written assent must be documented and witnessed. Thus each class teacher was in attendance and witnessed the participants provide oral assent. 


\subsubsection{Locating a Matched Second School}

The research study required a sample size of 30 participants in order to calculate a statistical difference between the groups. Thus the principal of School A, as well as the school psychologist, were asked to recommend another school that was a match for School A within the municipality. School $B$ was recommended and contacted. The same recruitment procedure (3.10.3 - 3.10.7) was repeated with School B. Twenty-one of the 220 parents/guardians who were sent information letters gave consent to be contacted. Figure 1 provides a summary of the course of action. Fourteen participants were chosen from school $\mathrm{B}$.

\subsubsection{Locating a Matched Third School}

As a further eight participants were still required to complete the necessary sample size. Steps 3.10.2 to 3.10.7. were once again repeated. Seventeen of the 120 parents/guardians who were sent information letters gave consent to be contacted. Figure 1 provides a summary of the process followed. Six participants were chosen from School C.

\subsubsection{Locating a Matched Fourth School}

The researcher still required a final two participants. Steps 3.10.2 to 3.10.7. were once again repeated. Nineteen of the 90 parents/guardians who were sent information letters gave consent to be contacted. Figure 1 provides a summary of the process followed. Two participants were recruited from School D. 
Figure 1: Summary of Recruitment Procedures

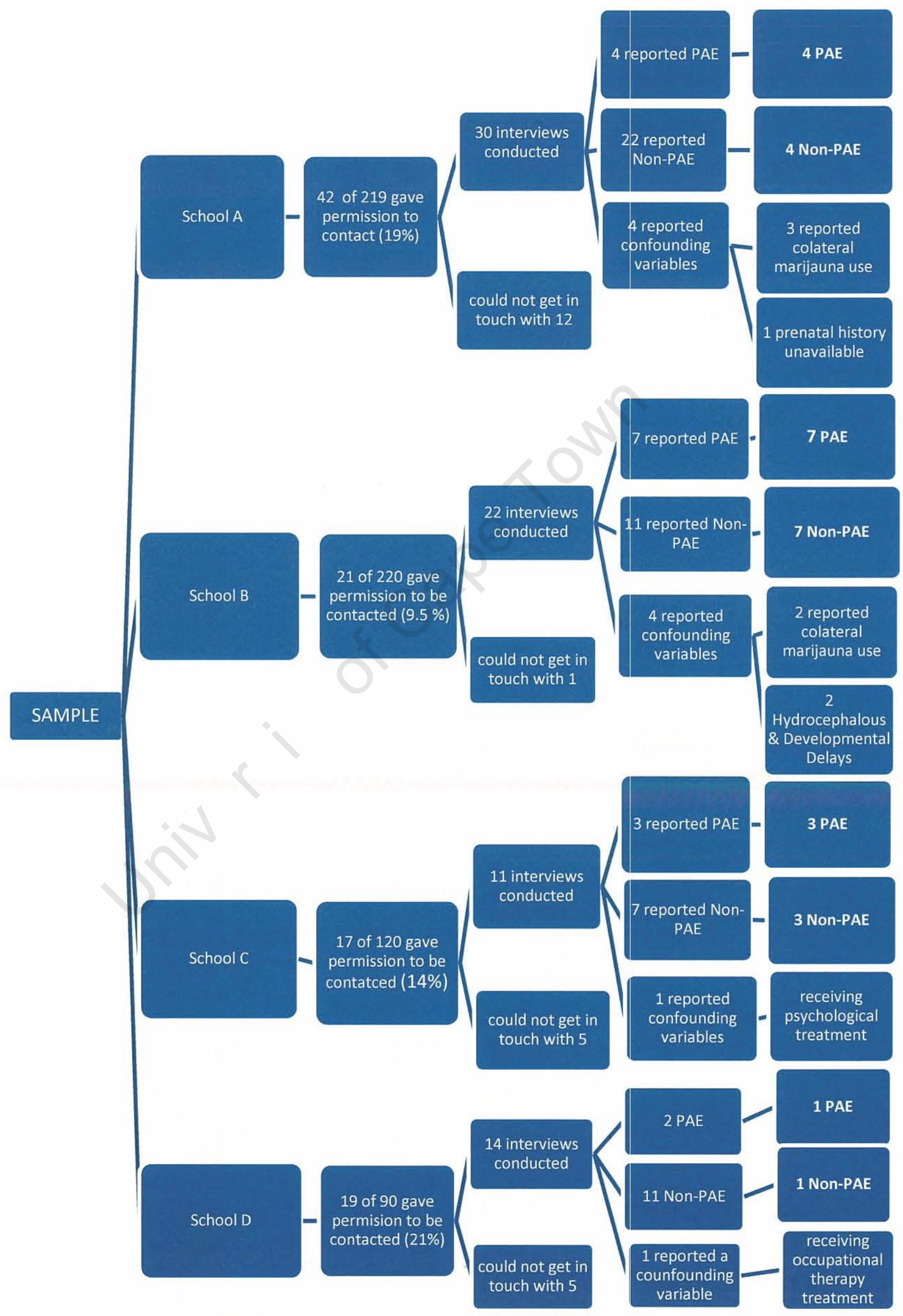




\subsection{Ethical Considerations}

Ethics approval was obtained from the University of Cape Town's Human Research Ethics Committee (HREC REF: 532/2011) in November 2011 (see Appendix I).

No further contact was made with parents who did not return the information to be contacted forms. Informed parental consent and learner assent was obtained before commencing with data collection. It was emphasised to the participants and their parents that they had the right to withdraw from the study at any point; none chose to do so. During filming, a reasonable distance from the participants was maintained so as not to interrupt their play or to draw too much attention to them and their group of friends. Recording was stopped on one occasion to prevent a group of children from physically assaulting another child. The incident was referred to the teacher on playground duty, who handled the situation in accordance with school policy.

\subsection{Data Collection}

\subsubsection{Filming the Participants}

Participants were filmed during the period of March to May 2012. Approximately 14 hours were required to complete filming. A research assistant who was familiar with the context and use of recording equipment was hired to assist with the filming.

Some degree of responder bias was expected due to the novelty of the film equipment in the lower socioeconomic areas in which the schools were located. Most of the responder bias was, however, observed to wear off approximately five minutes after filming began. It was noted that the grade one's hardly seemed to notice that they were being filmed, while the older children appeared to be more interested in the filming that took place. 
Data was collected by video-taping 15 minute observations of each of the participants engaging in free play on their school playground, during breaktime. However, due to occasional difficulties with tracking the children during their play, approximately eight of the 30 films were limited to footage lasting between 12 to 15 minutes. All the video tapes were mixed and divided into three groups of ten each, before being given to the three trained and calibrated raters of the ToP for scoring. The raters were 'blinded' as they did not know which of the tapes belonged to Children with PAEand which of the tapes belonged to the non-PAE group. Researcher bias was thus eliminated.

\subsubsection{Administering the Test of Playfulness}

The normal procedure that is followed when administering the ToP is to enter each score from the ToP Protocol Sheet (see Appendix P) into the ToP Keyform (see Appendix Q). The ToP Keyform displays the difficulty of each of the ToP's items plotted against the means and standard deviations for the items and is called the measure score (Skard \& Bundy, 2008). Measure scores are interval level scores which can be used for statistical analysis.

For the purpose of obtaining statistically accurate data, the researcher collaborated with the author of the ToP in order to have the scores of the study's raters calibrated. Following calibration and the scoring of the two groups, the researcher collected the item scores and sent a copy of the scores to the author of the ToP. The scores were then run through the Rasch Measurement Software and a set of overall measure scores were obtained.

\subsection{Data Management and Statistical Analysis}

Steps were taken to ensure that the security and completeness of the data was maintained. Two copies of each tape were made immediately after filming each participant. The tapes were labelled with a numbered code (known only to the researcher) in order to protect the confidentiality of the participants. Tapes were kept in two secure locations on the researcher's 
property and scorers were provided with a copy of the original tape to score, in order to ensure that no data was lost.

A statistician was hired to assist with the data analysis. The participants biographical information and raw scores from the ToP were entered into an excel spreadsheet. The data was then imported into SAS/JMP version ten SAS Institute, 2012). A dictionary was created by allocating variable names and value labels to the data. Measurement types were identified and allocated to the variables (nominal, ordinal and continuous measurement types). The data was verified by performing a frequency analysis upon nominal/ordinal variables and measures of location and dispersion, as well as the distributions of continuous data. Erroneous/anomalous data was identified by inspection and corrected. Since the Test of Playfulness is a standardised and calibrated instrument no validation was performed.

Descriptive analysis was performed on the PAE group and the non-PAE group to determine similarities and differences between them. Chi-squared tests were performed on categorical variables and t-tests were performed on the continuous variables.

The excel spreadsheet containing the study's raw data was sent to the author of the ToP. The data was run through the Rasch Measurement Software. The Rasch analysis generates two types of statistics (Wright \& Masters, 1982). The first set is known as infit and outfit statistics, whilst the second set of statistics provides measure scores on which subsequent analyses can be conducted (Okimoto, Bundy \& Handzik, 2000). Fit statistics determine the goodness-of-fit between the items, raters, and study participants to the Rasch Analysis (Okimoto, Bundy \& Hanzlik, 2000). The mean square $(\mathrm{MnSq})$ score should not be greater than 1.4, while the standard (Std) score should not be greater than 2. If both the MnSq and Std score are out of range for either of the infit or outfit scores, the rating can be said to be erratic and results should be viewed cautiously. The second set of 
statistics generated are known as measure scores. Measure scores are created when the Rasch analysis converts ordinal level scores into interval level. In order to investigate whether or not there was a difference in the overall playfulness scores between the PAE group and non-PAE group, the measure scores were subjected to a paired t-test.

When investigating differences in scores on the individual items of the ToP, data was analysed and either subjected to parametric or non-parametric tests. In cases where the data was normally distributed the scores were analysed using the parametric tests, such as the one-way ANOVA test (Hicks, 2009). When ToP scores generated were abnormally distributed, the scores were analyzed using non-parametric tests, such as the Wilcoxon Signed-Ranks Test. This form of analysis is used as a non-parametric t-test equivalent (Hicks, 2009). P-value's of less than 0.05 were used to indicate significant differences at the $95 \%$ level of confidence, i.e. if a p-value was less than 0.05 , there is a $95 \%$ certainty that there are differences between the mean PAE and Non-PAE scores. 


\section{CHAPTER 4: RESULTS}

\subsection{Introduction}

This chapter presents the study's findings. The chapter begins by providing an overview of the parental/guardian response rates to participation in the study. Thereafter, differences and similarities between the two groups across their biographical details will be described. The central part of the chapter presents the analysis of participants' measure scores, in order to determine whether a relationship exists between prenatal alcohol exposure and playfulness. Fit statistics and unexpected scores generated by the Rasch Measurement Software are then described. The chapter concludes by summarising the findings.

\subsection{Response Rate}

Only 99 of the 649 (15.25\%) parents who were sent information forms returned the consent to be contacted forms. The researcher was able to interview 77 of the $99(77.78 \%)$ who had returned the permission to be consented forms. During the interview process, ten of the 77 (12.99\%) were excluded from partaking in the prenatally exposed group, due to confounding variables. Refer to Figure 1 for more detail on the nature of the confounding variables.

Once the sample was selected, all the parents/guardians gave permission for their children to be part of the study and all the participants gave verbal informed assent.

\subsection{Biographical Profile of the Respondents}

Biographical information was obtained from the participants parents/guardians during the interview process. A comparison of the 
biographical information across the PAE and non-PAE group can be found in Table 2.

This section will describe the sample's age; gender; custodianship; time spent in grade one; exposure to prenatal alcohol exposure; alcohol intake; and exposure to nicotine.

Table 2: Comparison of Biographical Information Across the Prenatal Alcohol Exposed Group and the nonPrenatal Alcohol Exposed Group

\begin{tabular}{|c|c|c|c|c|c|}
\hline & & $\begin{array}{l}\text { PAE Group } \\
(\mathrm{N}=15)\end{array}$ & $\begin{array}{l}\text { Non-PAE Group } \\
(\mathrm{N}=15)\end{array}$ & Statistic & p-value \\
\hline \multirow[t]{2}{*}{ Gender } & Male & 8 (53.33\%) & $7(46.66 \%)$ & \multirow{2}{*}{ Chi-sq $=0$} & \multirow{2}{*}{$p=1.00$} \\
\hline & Female & $7(46.66 \%)$ & $8(53.33 \%)$ & & \\
\hline \multicolumn{2}{|c|}{ Mean (SD) Age } & $\begin{array}{c}7.05 \\
(S D=0.50)\end{array}$ & $6.81(\mathrm{SD}=0.58)$ & $t=1.19$ & $P=0.24$ \\
\hline \multirow{2}{*}{ Custodian } & Parent & $11(73.34 \%)$ & $15(100 \%)$ & \multirow{2}{*}{ Chi-sq $=4.62$} & \multirow{2}{*}{$p=0.03 *$} \\
\hline & Guardian & $4(26.67 \%)$ & $0(0 \%)$ & & \\
\hline \multirow{2}{*}{$\begin{array}{c}\text { No. of } \\
\text { Years in } \\
\text { Grade One }\end{array}$} & $1^{\text {st }}$ year & $10(66.67 \%)$ & $14(93.33 \%)$ & \multirow{2}{*}{ Chi-sq $=3.33$} & \multirow{2}{*}{$p=0.07$} \\
\hline & Repeat year & $5(33.34 \%)$ & $1(6.67 \%)$ & & \\
\hline \multirow{4}{*}{$\begin{array}{l}\text { Alcohol } \\
\text { Intake }\end{array}$} & Non & $0(0 \%)$ & $15(50 \%)$ & \multirow{4}{*}{$\begin{array}{l}\text { Unable to } \\
\text { calculate due to } \\
\text { lack of cell } \\
\text { density. }\end{array}$} & \multirow{4}{*}{$\begin{array}{l}\text { Only the PAE } \\
\text { group were } \\
\text { exposed to } \\
\text { alcohol in-utero. }\end{array}$} \\
\hline & Minimal & $5(33.34 \%)$ & $0(0 \%)$ & & \\
\hline & Moderate & $5(33.34 \%)$ & $0(0 \%)$ & & \\
\hline & Heavy & $5(33.34 \%)$ & $0(0 \%)$ & & \\
\hline \multirow{3}{*}{$\begin{array}{l}\text { Exposure } \\
\text { to Nicotine }\end{array}$} & Smoking & $9(60 \%)$ & $1(6.67 \%)$ & \multirow{3}{*}{ Chi-sq=10.64 } & \multirow{3}{*}{$p=0.00 *$} \\
\hline & $\begin{array}{c}\text { Non- } \\
\text { Smoking }\end{array}$ & $5(33.34 \%)$ & $14(93.34 \%)$ & & \\
\hline & Unknown & $1(6.67 \%)$ & $0(0 \%)$ & & \\
\hline
\end{tabular}

\subsubsection{Age}

The mean age of the sample was 6.97 years $(S D=0.50)$. As illustrated in Figure 2, the participants were normally distributed with regards to age. There were no significant differences between the ages of the PAE group 
$(M=7.05 ; S D=0.50)$ and the ages of the non-PAE group $(M=6.81 ; S D=0.58$; $t=1.19 ; d f=28 ; p=0.24)$.

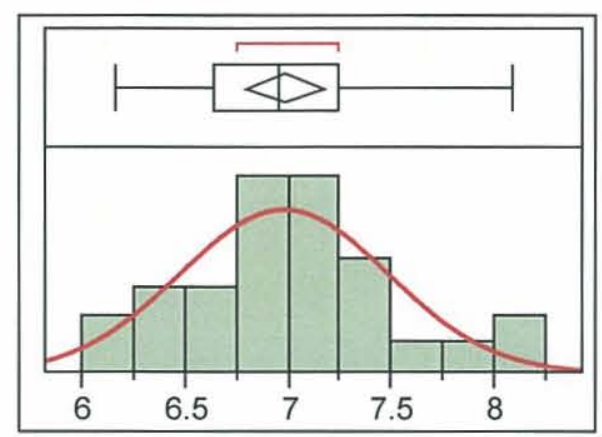

Figure 2: Sample Age Distribution

\subsubsection{Gender}

Slightly more males than females took part in the study (see Figure 3). Although the difference was not significant, the PAE group had more males $(53 \%)$ than females (46\%). The gender ratio was inversely represented in the non-PAE group.

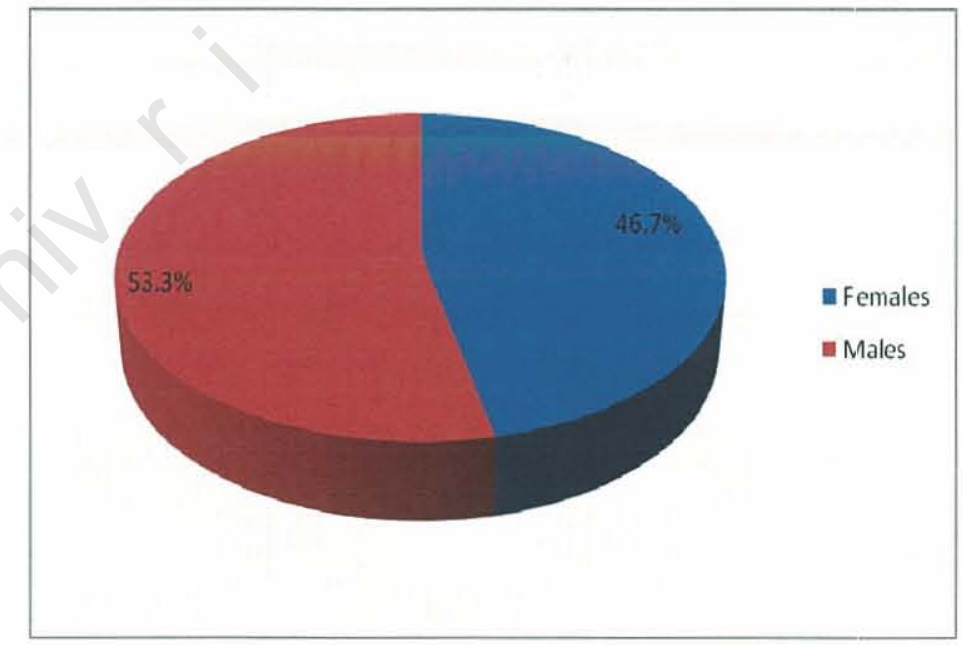

Figure 3: Sample Gender Distribution

\subsubsection{Custodian}

The majority of the sample were in the care of their biological parent(s), whilst a minority had been placed in the care of guardians (see Figure 4). All 
of those that had been placed in the care of guardian's formed part of the PAE group, and accounted for $26.67 \%$ of their group.

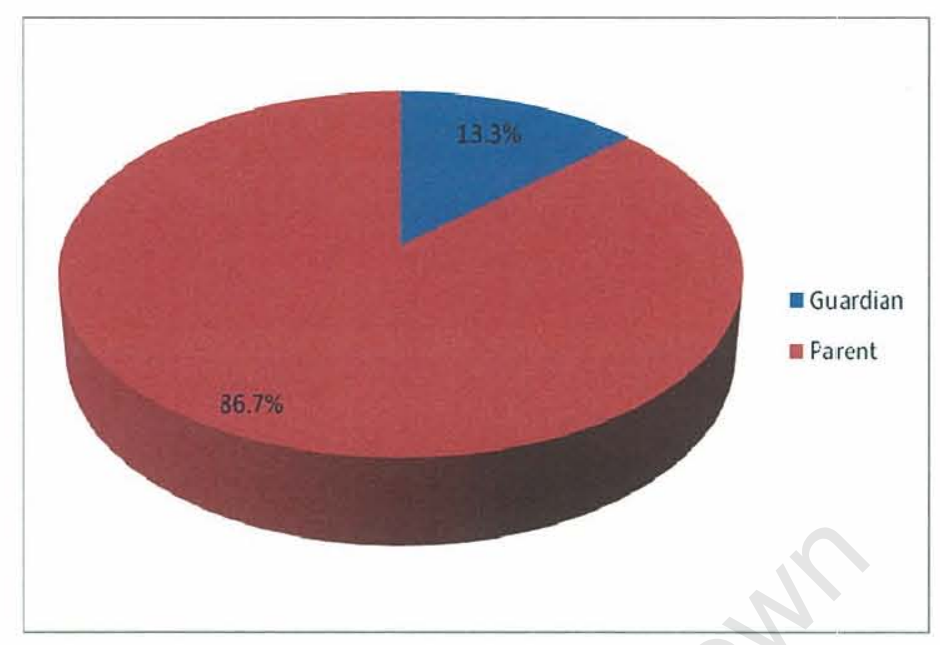

Figure 4: Sample Custodianship

\subsection{4. $1^{\text {st }}$ Year in Grade One/Repeat Year:}

The majority of the participants were in their first year of grade one, whilst a minority group were repeating the year (see Figure 5). No significant difference was found between the number of children which repeated grade one in the PAE group and the number of children who repeated grade one in the non-PAE group $(p=0.08)$. However, one third of the participants that constituted the PAE group were repeating the year, whilst only one of the 15 (6.67\%) participants which constituted the non-PAE group was repeating the year. Children were required to repeat the year when the results of their academic assessments indicated that they had not made the progress required to advance to grade two. 


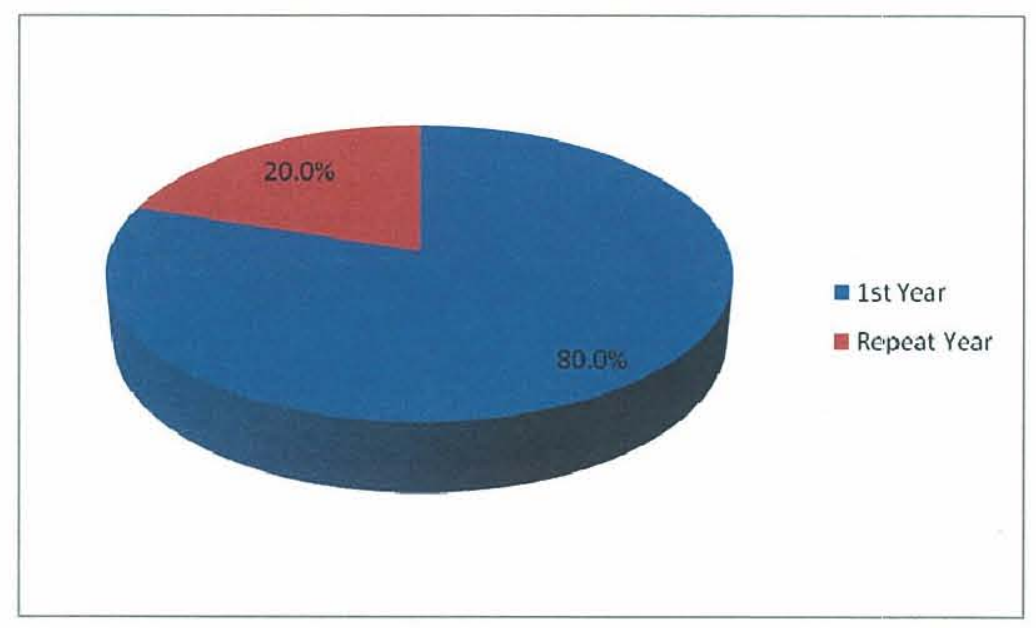

Figure 5: Number of Years in Grade One for Sample

\subsubsection{Prenatal Alcohol Exposure}

The number of children in each group was equally distributed between the groups (see Figure 6).

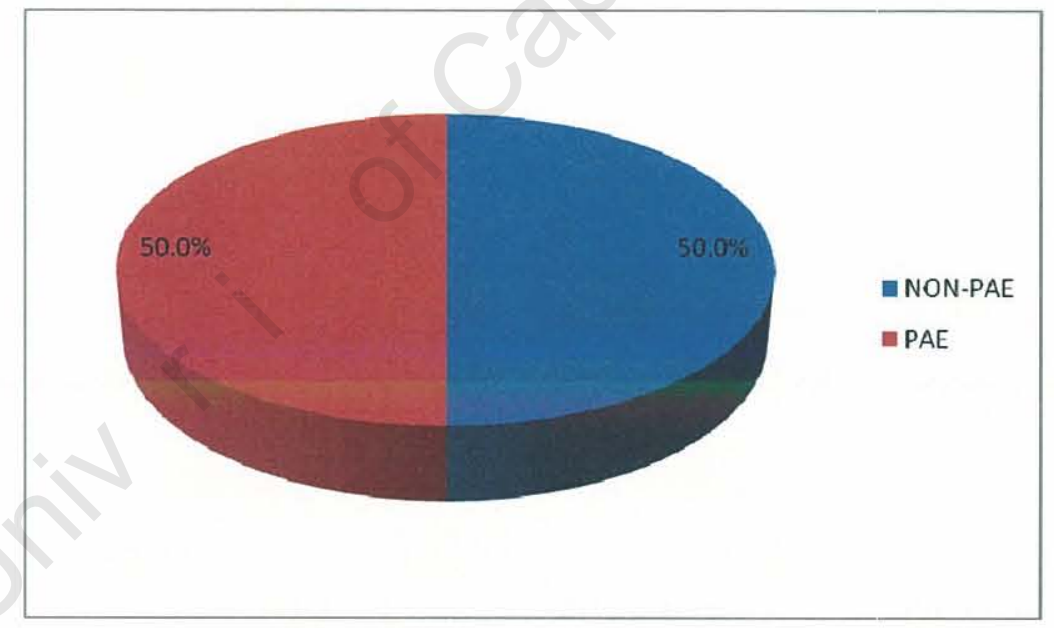

Figure 6: Percentage of Children in Each Group

\subsubsection{Alcohol Intake}

Alcohol intake can be recorded in units of alcohol equal to $10 \mathrm{ml}$ of absolute alcohol (AA) (Croxford \& Viljoen, 1999). This system of clarification was used to describe the amount of alcohol each mother had consumed during pregnancy (refer to the definition of terms for categories of alcohol intake). 
The PAE group were found to be equally dispersed between the three levels of minimal, moderate, and heavy alcohol intake (see Figure 7). None of the mothers of the non-PAE group consumed any alcohol during their pregnancies.

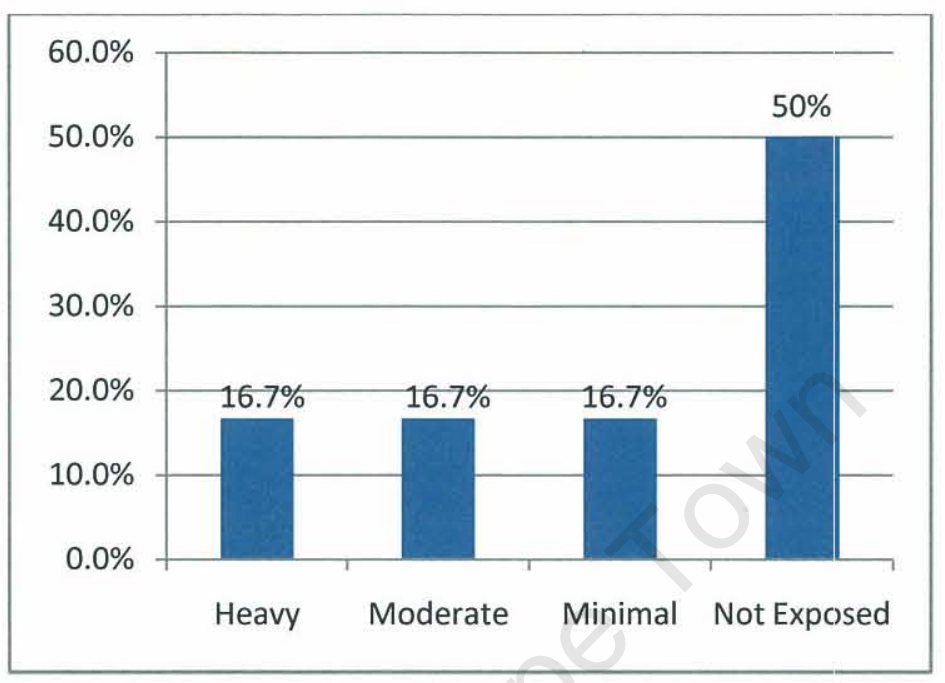

Figure 7: Parental Alcohol Intake for Sample

\subsubsection{Exposure to Nicotine}

Almost one third of the sample were exposed to nicotine prenatally (see Figure 8). There was a significant difference in exposure to nicotine between the groups $(p=0.00)$. Nine of the $15(60 \%)$ participants that constituted the PAE group were exposed to nicotine in-utero, while information regarding the nicotine exposure of 1 participant in the PAE group was unavailable. Only one of the $15(6.67 \%)$ participants who constituted the non-PAE group was exposed to nicotine prenatally. 


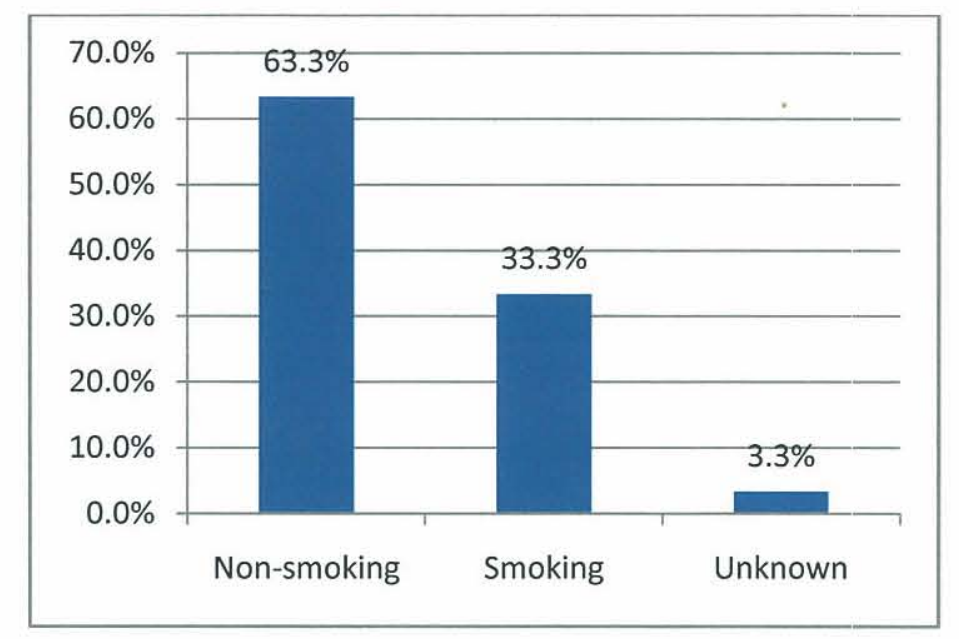

Figure 8: Nicotine Exposure of the Sample

\subsection{Playfulness Scores}

To answer the primary research question of - how do the levels of playfulness of children who have been prenatally exposed to alcohol compare to those who were not prenatally exposed to alcohol?' - the researcher analysed the measure scores provided by the Rasch analysis (see Table 3).

Table 2: Comparison of Playfulness Scores between Groups

\begin{tabular}{|c|l|c|c|c|}
\hline \multirow{2}{*}{ Playfulness } & $\begin{array}{c}\text { Prenatal } \\
\text { Alcohol } \\
\text { Exposure }\end{array}$ & $\begin{array}{c}\text { Mean } \\
\text { Measure } \\
\text { Score }\end{array}$ & $\begin{array}{c}\text { Std } \\
\text { Deviation }\end{array}$ & $\begin{array}{c}\mathrm{p} \text { - } \\
\text { value }\end{array}$ \\
\cline { 2 - 4 } & PAE-PAE & 0.39 & 1.33 & \multirow{2}{*}{0.02} \\
\hline
\end{tabular}

\subsubsection{Group Not Exposed to Alcohol Prenatally}

A mean measure score of 0.39 was calculated, with a standard deviation of 1.33.

The results of the Shapiro-Wilk W distribution test indicated that the measure scores for the non-PAE group were normally distributed $(\mathrm{Prob}<\mathrm{W}=0.12$ ) (see Figure 9). The majority of the non-PAE group thus had mean measure scores that were close to the average of 0.39 . The non-PAE mean measure 
score was thus slightly higher than the approximate mean $(M=0.33)$ of children with normal playfulness scores in the Test of Playfulness data set (Skard \& Bundy, 2008).

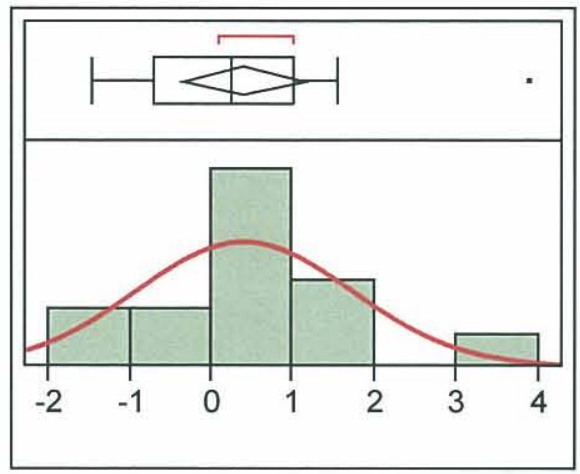

Figure 9: Distribution of Non-Prenatal Alcohol Exposed Group Measure Scores

\subsubsection{Group Exposed to Alcohol Prenatally}

A mean measure score of -0.62 was calculated, with a standard deviation of 0.97.

The results of the Shapiro-Wilk W distribution test indicated that the measure scores for PAE were normally distributed (Prob<W = 0.87) (see Figure 10). Thus the majority of the PAE group had mean measure scores which were close to the average of -0.62 . The PAE mean measure score was therefore less than the approximate mean $(M=-0.33)$ of children with lower playfulness scores in the Test of Playfulness data set (Skard \& Bundy, 2008).

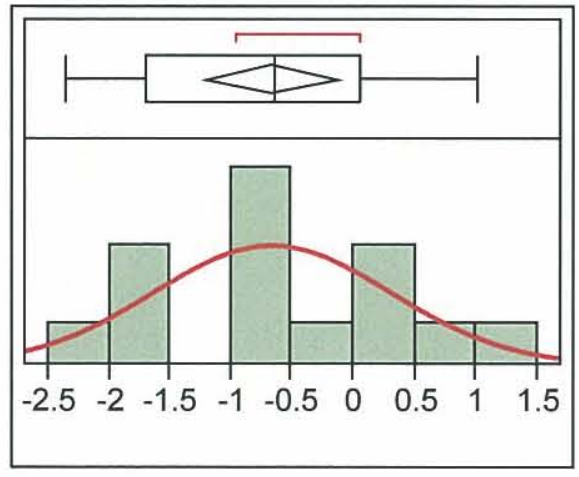

Figure 10: Distribution of Prenatal Alcohol Exposed Measure Scores 
4.4.3. Comparison of the non-Prenatally Exposed Group with the Prenatally Exposed Group

The results of the t-test indicated that the PAE group had a significantly lower mean playfulness score than the non-PAE group $(p=0.02)$ (see Figure 11).

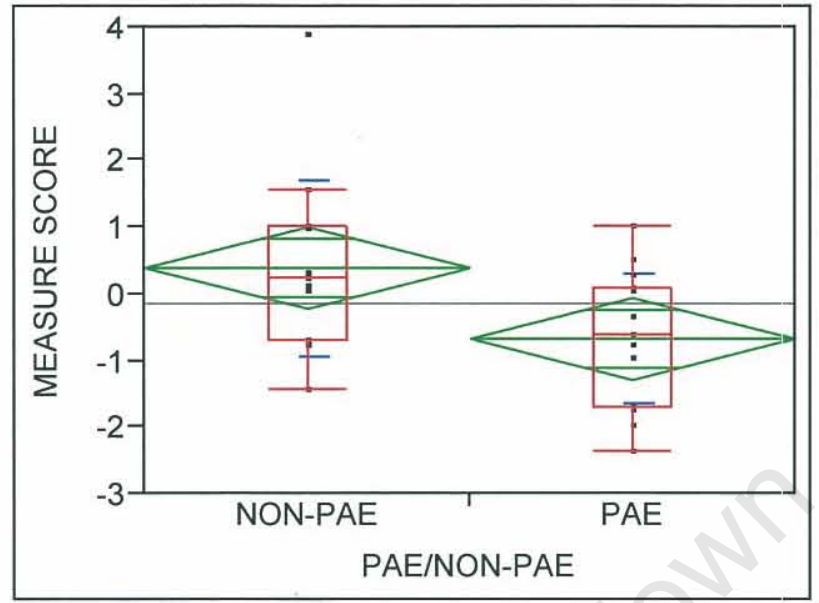

Figure 11: Oneway Analysis of Measure Scores

\subsubsection{Homogeneity of the Variances}

A p-value of 0.51 on the Levene Test confirmed the homogeneity of the variances. Equality of the variances (how far the scores were spread out) was therefore established.

\subsection{Comparison of Items on the Test of Playfulness which Reflect Social Play}

To explore the research objectives of investigating how the PAE group and the non-PAE group compared on individual items which related to social playfulness, both parametric and non-parametric tests were used. Due to a relatively small sample size, normality was not tested when determining differences on the individual items. Instead, both parametric and nonparametric tests were used, and when both p-value's were less than $0.05 \mathrm{a}$ relationship was cautiously determined. If one test was less than 0.05 the difference was rejected. Table 4 represents the results for items of the Test of Playfulness (ToP) which showed significant differences. These items included: the extent to which participants clowned or joked with others; the 
intensity of the participants social play; the skill with which participants modified their engagement in play; the skill with which participants engaged in social play; the skill with which participants initiated play; the skill with which participants clowned or joked with others; and the skill with which participants transitioned from one play activity to another.

Table 3: Item Scores

\begin{tabular}{|c|c|c|c|c|c|c|c|c|}
\hline \multirow{2}{*}{ ToP Item } & \multirow{2}{*}{$\begin{array}{l}\text { Prenatal } \\
\text { Alcohol } \\
\text { Exposure }\end{array}$} & \multirow{2}{*}{ Mean } & \multirow{2}{*}{$\begin{array}{c}\text { Std } \\
\text { Deviation }\end{array}$} & \multirow{2}{*}{ DF } & \multicolumn{2}{|c|}{$\begin{array}{l}\text { Parametric } \\
\text { Test: T-test }\end{array}$} & \multicolumn{2}{|c|}{$\begin{array}{l}\text { Non-Parametric } \\
\text { Test: Wilcoxon }\end{array}$} \\
\hline & & & & & $\begin{array}{c}\text { F- } \\
\text { Ratio }\end{array}$ & $\begin{array}{c}\mathrm{p}- \\
\text { value }\end{array}$ & $\begin{array}{l}\text { Chi-Sq } \\
\text { Statistic }\end{array}$ & $\begin{array}{c}\mathrm{p}- \\
\text { value }\end{array}$ \\
\hline \multirow{2}{*}{ Engaged $\mathrm{E}$} & Non-PAE & 1.93 & 1.10 & \multirow{2}{*}{1} & \multirow{2}{*}{2.76} & \multirow{2}{*}{0.11} & \multirow{2}{*}{2.59} & \multirow{2}{*}{0.11} \\
\hline & PAE & 1.27 & 1.10 & & & & & \\
\hline \multirow{2}{*}{ Decides E } & Non-PAE & 2.13 & 1.06 & \multirow{2}{*}{1} & \multirow{2}{*}{1.03} & \multirow{2}{*}{0.32} & \multirow{2}{*}{1.09} & \multirow{2}{*}{0.30} \\
\hline & PAE & 1.73 & 1.10 & & & & & \\
\hline \multirow{2}{*}{ Safety E } & Non-PAE & 2.33 & 0.90 & \multirow{2}{*}{1} & \multirow{2}{*}{2.86} & \multirow{2}{*}{0.10} & \multirow{2}{*}{2.76} & \multirow{2}{*}{0.10} \\
\hline & PAE & 1.71 & 1.07 & & & & & \\
\hline \multirow{2}{*}{$\begin{array}{l}\text { Mischief/ } \\
\text { Teasing E }\end{array}$} & Non-PAE & 1.07 & 0.88 & & 207 & 016 & 161 & \\
\hline & PAE & 0.67 & 0.62 & 1 & 2.07 & 0.10 & 1.01 & 0.20 \\
\hline Procesc F & Non-PAE & 1.20 & 0.90 & 1 & 119 & 028 & 105 & 031 \\
\hline Process E & PAE & 1.00 & 1.10 & 1 & 1.19 & $0 . \angle 0$ & 1.00 & 0.31 \\
\hline Protendc F & Non-PAE & 0.45 & 0.93 & 1 & 211 & 0.16 & 273 & 010 \\
\hline Pretenas E & PAE & 0.00 & 0.00 & 1 & 2.11 & 0.10 & 2.13 & 0.10 \\
\hline Unconventional & Non-PAE & 1.07 & 1.03 & 1 & 380 & 006 & 463 & 003 \\
\hline $\mathrm{E}$ & PAE & 0.40 & 0.82 & $\perp$ & 0.00 & 0.00 & 4.00 & 0.00 \\
\hline Social Plav F & Non-PAE & 2.13 & 1.06 & 1 & 385 & 0.06 & 351 & 0.06 \\
\hline Solciat tay L & PAE & 1.40 & 0.99 & $\perp$ & 0.00 & 0.00 & 0.01 & 0.00 \\
\hline Clounc/lokec F & Non-PAE & 1.0 & 0.85 & 1 & 700 & $001 \%$ & 58 & (20\% \\
\hline CIOWIIS/JOKES L & PAE & 0.33 & 0.49 & 1 & 1.00 & $0.01 \%$ & 0.0 & $0.02 \%$ \\
\hline & Non-PAE & 1.73 & 0.96 & 1 & 070 & 010 & 077 & 015 \\
\hline Gives cues E & PAE & 1.47 & 0.74 & 1 & 0.12 & 0.40 & 0.51 & 0.40 \\
\hline Engaged 1 & Non-PAE & 2.20 & 0.94 & 1 & 201 & 010 & 204 & 0 \\
\hline cingageu I & PAE & 1.60 & 0.99 & 1 & 2.91 & 0.10 & 2.94 & 0.09 \\
\hline Dercict I & Non-PAE & 1.80 & 0.94 & 1 & 174 & ח 0 & 168 & 010 \\
\hline FeISISt & PAE & 1.31 & 1.03 & 1 & 1.14 & $0 . \angle 0$ & 1.00 & 0.19 \\
\hline Social Play ! & Non-PAE & 2.20 & 0.78 & 1 & 700 & $001:$ & 565 & \\
\hline Soctair tay & PAE & 1.47 & 0.74 & 1 & 1.00 & $0.01 *$ & 5.65 & $0.02 *$ \\
\hline$\Delta \mathrm{ffect}$ l & Non-PAE & 1.73 & 0.88 & 1 & 256 & 012 & 226 & 013 \\
\hline HIIECl & PAE & 1.20 & 0.94 & $\perp$ & 2.00 & 0.12 & 2.20 & 0.10 \\
\hline Interaction & Non-PAE & 0.83 & 0.94 & 1 & 0.04 & $084+24+2$ & רחת & ר \\
\hline with Objects I & PAE & 0.92 & 1.08 & 1 & 0.04 & 0.04 & 0.02 & 0.90 \\
\hline Fnoaged S & Non-PAE & 2.07 & 0.80 & 1 & 136 & $0 ? 5$ & 115 & 028 \\
\hline Eilgageu & PAE & 1.71 & 0.83 & 1 & 1.00 & $0 . \angle 0$ & 1.15 & $0 . \angle 0$ \\
\hline Mnd & Non-PAE & 1.20 & 0.86 & 1 & 560 & $002 *$ & $533>>>>$ & ก0?* \\
\hline IVIunin & PAE & 0.46 & 0.78 & 1 & 0.00 & 0.00 & 0.00 & $0.0<*$ \\
\hline Mischief/ & Non-PAE & 1.36 & 0.84 & 1 & 2.95 & 0.10 & 0.84 & 0.69 \\
\hline
\end{tabular}




\begin{tabular}{|c|c|c|c|c|c|c|c|c|}
\hline Teasing S & PAE & 0.85 & 0.69 & & & & & \\
\hline \multirow{2}{*}{ Pretends S } & Non-PAE & 0.78 & 1.09 & \multirow{2}{*}{1} & \multirow{2}{*}{3.49} & \multirow{2}{*}{0.08} & \multirow{2}{*}{3.80} & \multirow{2}{*}{0.05} \\
\hline & PAE & 0.00 & 0.00 & & & & & \\
\hline \multirow{2}{*}{$\begin{array}{c}\text { Unconventional } \\
\mathrm{S}\end{array}$} & Non-PAE & 1.15 & 0.90 & \multirow{2}{*}{1} & \multirow{2}{*}{3.95} & \multirow{2}{*}{0.06} & \multirow{2}{*}{5.02} & \multirow{2}{*}{0.03} \\
\hline & PAE & 0.46 & 0.88 & & & & & \\
\hline \multirow{2}{*}{ Negotiates S } & Non-PAE & 1.40 & 0.99 & \multirow{2}{*}{1} & \multirow{2}{*}{1.60} & \multirow{2}{*}{0.22} & \multirow{2}{*}{1.02} & \multirow{2}{*}{0.31} \\
\hline & PAE & 1.00 & 0.68 & & & & & \\
\hline \multirow{2}{*}{ Social Play S } & Non-PAE & 2.00 & 0.76 & \multirow{2}{*}{1} & \multirow{2}{*}{4.85} & \multirow{2}{*}{$0.04 *$} & \multirow{2}{*}{4.19} & \multirow{2}{*}{$0.04 *$} \\
\hline & PAE & 1.40 & 0.74 & & & & & \\
\hline \multirow{2}{*}{ Supports S } & Non-PAE & 1.47 & 0.74 & \multirow{2}{*}{1} & \multirow{2}{*}{1.80} & \multirow{2}{*}{0.19} & \multirow{2}{*}{1.97} & \multirow{2}{*}{0.16} \\
\hline & PAE & 1.07 & 0.88 & & & & & \\
\hline \multirow{2}{*}{ Enters S } & Non-PAE & 1.53 & 1.06 & 1 & 268 & 011 & 252 & 011 \\
\hline & PAE & 0.93 & 0.92 & 1 & 2.00 & 0.11 & 2.03 & 0.11 \\
\hline Initiatec $\mathrm{S}$ & Non-PAE & 1.80 & 1.01 & & 847 & $001 \%$ & 6.15 & $001 *$ \\
\hline Inıtıates S & PAE & 0.77 & 0.83 & 1 & 8.47 & $0.01 *$ & 6.45 & $0.01 *$ \\
\hline Clouncl lokecs & Non-PAE & 1.14 & 0.54 & 1 & 533 & & 476 & $002 *$ \\
\hline Clowns/ Jokes s & PAE & 0.62 & 0.65 & 1 & 5.33 & $0.03 \%$ & 4.16 & $0.03 \%$ \\
\hline Choroc $\mathrm{C}$ & Non-PAE & 1.46 & 1.05 & 1 & & 009 & 120 & ב? 07 \\
\hline snares s & PAE & 1.00 & 1.04 & 1 & 1.21 & 0.28 & 1.22 & 0.27 \\
\hline & Non-PAE & 1.80 & 0.94 & & & & & 0.07 \\
\hline GIves S & PAE & 1.20 & 0.68 & 1 & 4.02 & 0.05 & 3.29 & 0.07 \\
\hline Rocnonde $\mathrm{S}$ & Non-PAE & 1.80 & 0.78 & 1 & 123 & 028 & (2) & 037 \\
\hline Responas s & PAE & 1.53 & 0.52 & 1 & 1.23 & 0.28 & 0.80 & 0.31 \\
\hline Interaction & Non-PAE & 0.90 & 0.88 & 1 & 0,43 & 0.52 & 0.27 & 0.60 \\
\hline with objects S & PAE & 1.18 & 1.08 & 1 & 0.43 & 0.52 & 0.27 & 0.60 \\
\hline Tran & Non-PAE & 2.00 & 1.00 & 1 & 774 & $001 *$ & 583 & $00 \%$ * \\
\hline transitions s & PAE & 0.909 & 0.83 & 1 & 1.14 & $0.01 \%$ & 0.03 & $0.02 \%$ \\
\hline
\end{tabular}

Results therefore indicate that children with PAE scored significantly poorer on five of the $12(41.67 \%)$ ToP items related to social playfulness than their non-PAE counterparts. These items were: the extent to which participants clowned or joked with others; the intensity of the participants social play; the skill with which participants engaged in social play; the skill with which participants initiated play; and the skill with which participants clowned or joked with others. A description of these items can be found in Table 5, with accompanying comments from raters. 


\begin{tabular}{|c|c|c|}
\hline Item & Description & Raters' Comments \\
\hline $\begin{array}{l}\text { Engages in Social Play } \\
\text { (Intensity) }\end{array}$ & $\begin{array}{l}\text { The depth of the player's } \\
\text { interactions with other people } \\
\text { during play. }\end{array}$ & $\begin{array}{l}\text { "seldom interacted with } \\
\text { those sitting with her" }\end{array}$ \\
\hline Engages in Social Play (Skill) & $\begin{array}{l}\text { The level of social play. Ranges } \\
\text { from playing alone to being the } \\
\text { leader. }\end{array}$ & $\begin{array}{l}\text { "fighting only observed"; } \\
\text { "play-fighting only" }\end{array}$ \\
\hline $\begin{array}{l}\text { Initiates play with others } \\
\text { (Skill) }\end{array}$ & $\begin{array}{l}\text { Ease with which the player } \\
\text { initiates a new activity with } \\
\text { another. }\end{array}$ & $\begin{array}{l}\text { "once or twice"; "rarely"; } \\
\text { "really struggled to do } \\
\text { this effectively"; "only } \\
\text { towards the end"; } \\
\text { "seemed to struggle"; } \\
\text { "only watched groups, } \\
\text { but didn't join in" }\end{array}$ \\
\hline Clowns or jokes (Extent) & $\begin{array}{l}\text { Proportion of time when } \\
\text { players tell jokes or funny } \\
\text { stories or engage in } \\
\text { exaggerated, swaggering } \\
\text { behaviour, usually for the } \\
\text { purpose of gaining others' } \\
\text { attention. }\end{array}$ & $\begin{array}{l}\text { "appears to"; "only at the } \\
\text { end of break-time" }\end{array}$ \\
\hline Clowns or jokes (Skill) & $\begin{array}{l}\text { The ease or cleverness with } \\
\text { which a player clowns or jokes. } \\
\text { Ranges from not gaining } \\
\text { others' attention to gaining } \\
\text { positive reactions from others } \\
\text { to being overtly funny. }\end{array}$ & "difficult to assess" \\
\hline
\end{tabular}

Table 6 provides a description of the items related to social play which were not found to be statistically significant. These included: the skill with which participants negotiated with others to have their need or desires met during play; the extent with which participants engaged in social play; the skill with which participants supported the play of others; the skill with which participants entered a group already engaged in an activity; the skill with which participants shared; the extent with which participants gave readily 
understandable cues; and the extent with which participants responded to other's cues.

Table 6: Non-significant Scores Related to Social Playfulness

\begin{tabular}{|c|c|c|}
\hline Item & Description & Comments from Raters \\
\hline $\begin{array}{l}\text { Negotiates with others to have } \\
\text { needs/desires met (Skill) }\end{array}$ & $\begin{array}{l}\text { Ease and finesse with which } \\
\text { players verbally or nonverbally } \\
\text { ask for what they need. }\end{array}$ & $\begin{array}{l}\text { "allowed peer to } \\
\text { borrow spinning top } \\
\text { briefly" }\end{array}$ \\
\hline Engages in social play (Extent) & $\begin{array}{l}\text { Proportion of time during } \\
\text { which the player interacts with } \\
\text { others involved in the same or } \\
\text { similar activity. }\end{array}$ & No comment \\
\hline $\begin{array}{l}\text { Supports the play of others } \\
\text { (Skill) }\end{array}$ & $\begin{array}{l}\text { Ease with which players } \\
\text { support play of other (e.g. } \\
\text { encouragement, ideas). }\end{array}$ & $\begin{array}{l}\text { "only sometimes"; } \\
\text { "plays along, follows } \\
\text { rules" }\end{array}$ \\
\hline $\begin{array}{l}\text { Enters a group already } \\
\text { engaged in an activity (Skill) }\end{array}$ & $\begin{array}{l}\text { Ease with which the player } \\
\text { does something to become a } \\
\text { part of the group (two or } \\
\text { more) already engaged in an } \\
\text { activity; the action is not } \\
\text { disruptive of what is going on. }\end{array}$ & $\begin{array}{l}\text { "passive spectator } \\
\text { mostly"; "she tried"; } \\
\text { "joined watching } \\
\text { 'rapping"'; "groups } \\
\text { usually formed around } \\
\text { him"; "passive } \\
\text { member"; "not done } \\
\text { often" }\end{array}$ \\
\hline $\begin{array}{l}\text { Shares (toys, equipment, } \\
\text { friends, ideas) (Skill) }\end{array}$ & $\begin{array}{l}\text { The ease with which players } \\
\text { allow others to use toys, } \\
\text { personal belongings, or } \\
\text { equipment they are using or } \\
\text { share playmates (friends) or } \\
\text { ideas. }\end{array}$ & $\begin{array}{l}\text { "mostly food, but } \\
\text { probably also ideas"; } \\
\text { "mostly food, but also } \\
\text { ideas"; "didn't always } \\
\text { enjoy sharing" }\end{array}$ \\
\hline $\begin{array}{l}\text { Gives readily understandable } \\
\text { cues (facial, verbal, body) that } \\
\text { say, "This is how you should } \\
\text { act towards me." (Extent) }\end{array}$ & $\begin{array}{l}\text { Proportion of time during } \\
\text { which players act in a way to } \\
\text { give out clear messages about } \\
\text { how others should interact }\end{array}$ & $\begin{array}{l}\text { "unambiguous"; } \\
\text { "ignored mostly, even } \\
\text { when clearly wanted } \\
\text { her rope back"; }\end{array}$ \\
\hline
\end{tabular}


In addition, children with PAE were found to score significantly lower than the reference group on two other item scores not exclusively related to social play, namely 'Transitions' from one play activity to another with ease and 'Modifies' activity to maintain challenge or make the activity more fun (see Table 4). Raters comments for Transitions included "dropped a playmate with whom she initiated play for another; "moving from sitting to walking around"; and "engaged in same activity for entire clip". Raters comments for Modifies included "very little available to change"; "started chasing one boy"; and "only at end of clip".

\subsection{Person Response Validity}

Eight of the 30 (26.6\%) participants sampled had erratic person fit statistics. Five of these eight (16.67\%) participants belonged to the non-PAE group, whilst three $(10 \%)$ belonged to the PAE group. These participants scored highly on items that were difficult or poorly on items that vere easy (O'Brien \& Shirley, 2001). The scores for these children should therefore be viewed cautiously.

\subsection{Item Response Validity}

Unexpected ratings on individual items occurred on 30 of the 930 (3.23\%) items scored in the study. The assumptions of the Rasch Measurement Software are that all children will score highly on the easy items, whilst more 
playful children will score highly on harder items. Unexpected scores occur when children score poorly on easy items and/or well on more difficult items. A summary of the unexpected ratings can be found in Table 7 .

Table 7: Unexpected Scores

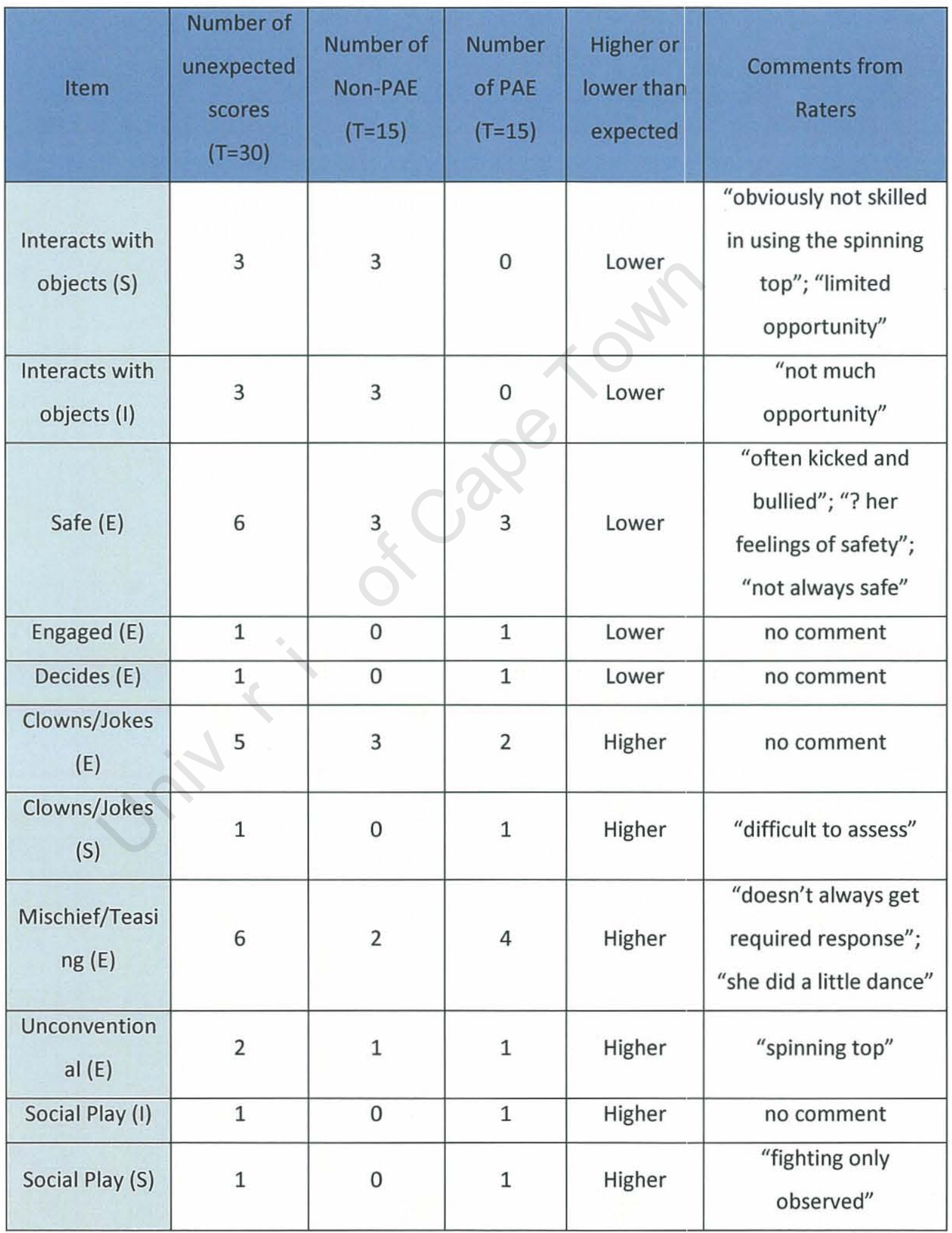




\subsection{Conclusion}

The prenatal alcohol exposed (PAE) group and the non-PAE group were similar with regards to their ages and gender. However, significantly more PAE participants lived with guardians as opposed to their biological parents. More PAE participants were also found to be repeating grade one. Mothers of the PAE group reported drinking varying amounts alcohol use during their pregnancies. Almost one third of all participants were exposed to nicotine prenatally and the majority of these participants belonged to the PAE group.

The PAE group were found to have significantly lower mean playfulness scores than the non-PAE group. The research hypothesis was therefore accepted. The PAE group was also found to have scored significantly lower on almost half of the items related to social play.

A quarter of the sample participants had erratic person fit statistics, with slightly more of these scores belonging to the non-PAE group. A small number of the sample had unexpected item fit statistics. Most of the higher than expected scores were recorded on the items 'clowns/jokes' and 'mischief/teasing', whilst the majority of the lower than expected scores were recorded on the items 'interacts with objects' and 'safety'. 


\section{CHAPTER 5: DISCUSSION}

\subsection{Introduction}

This chapter begins by discussing the response rate and sample composition. The primary result of interest - the quality of playfulness of children with prenatal alcohol exposure (PAE) - is then discussed. Implications of poorer playfulness scores for this population group are outlined. Thereafter, scores relating to social play are discussed in terms of existing research which demonstrates a link between PAE: and poorer social behaviour. The environmental impact on play is then considered, in order to ground the discussion of the study's findings in the context from which they arise. Subsequently, the potential role of South African occupational therapists working with this group is discussed. The chapter concludes by taking into account the limitations of the study.

\subsection{Response Rate and Sample Composition}

\subsubsection{Response Rate}

Although previous studies examining the prevalence of PAE in South African communities had reported good response rates (Croxford and Viljoen, 1991; May et al., 2008), this study had a low response rate of $15.25 \%$. Examination of the differences between the current study and previous research brings several ethical considerations to light. Previous studies were large prevalence studies which received greater publicity in the community and which were based in clinic settings (Croxford \& Viljoen, 1991). A clinic setting in which nurses assist to identify potential participants could increase the likelihood that participants provide information about their alcohol or risktaking behaviours due to power dynamics between health care practitioners and patients. This is markedly different from the written request for voluntary participation that was sent to all grade one parents/caregivers in this study, by a researcher not known to the parents/caregivers. 


\subsubsection{Comparison of Sample Composition to Existing Literature}

Croxford and Viljoen (1991) reported that $23.7 \%$ of mothers in their sample (the same community sampled in the current study) reported binge-drinking on weekends. This is similar to the $33.34 \%$ of mothers who reported heavy alcohol intake in the current study. In addition, levels of nicotine exposure were higher in the PAE group of the current study $(60 \%)$ than the PAE group of the Coxford and Viljoen (1991) study (36.5\%).

The $33.3 \%$ of children in the PAE group who repeated grade one were higher than the national average of 7.2\% (Department of Basic Education, 2011). In comparison, non-PAE group were slightly lower than the national average at $6.67 \%$. This finding is supported by O'Leary et al.'s (2008) report that deficits in social and intellectual functioning in children exposed to alcohol prenatally often lead to difficulties in school. More research is required to ascertain the exact relationship between early grade retention and PAE for this population.

\subsection{Prenatal Alcohol Exposure and Playfulness}

\subsubsection{Impact of Poorer Playfulness on Children's Health and Well-Being} The research hypothesis was supported when statistical results using the measure scores indicated that the PAE group performed significantly worse on their overall playfulness scores than the non-PAE group. Although causality cannot be determined, it can be said that there is a relationship between PAE and poorer levels of playfulness. This is a new finding in research regarding PAE and Foetal Alcohol Syndrome Disorders (FASD) and builds on existing literature that indicates a relationship between PAE and children's ability to play (Molteno et al., 2010). The result thus suggests that children with PAE are more likely to have a lowered disposition to play (playfulness) than their non-PAE counterparts.

This is an important finding when considering that play is a child's primary occupation (Parham, 2008). The occupational perspective of play has its roots in Sutton-Smith's (1997) rhetoric of play as self - which views play as 
intrinsically motivated and a contributor to an individual's identity construction (Parham, 2008). These assumptions underlie the concept of playfulness (Bundy, 2010). An individual's playfulness is a stable trait which guides his/her engagement in the occupation of play and influences the quality of his/her play (Brentall, Bundy \& Kay 2008; Hamm, 2006; O'Brien \& Shirley, 2001; Royeen, 1997). The research findings thus indicate that children who are prenatally exposed to alcohol are at risk to experience an enduringly poorer quality of play. Furthermore, previous research has demonstrated that playfulness scores correlate strongly with scores of coping, as both constructs share a thread of flexibility (Hess \& Bundy, 2003). Children with PAE have lower playfulness scores are thus also more likely to struggle to cope with the demands of everyday life.

Parham (2008:18) has proposed that occupational therapists develop an eighth rhetoric of play, that of "play as health", in order to acknowledge a shared assumption that play is an indicator and enabler of health and wellbeing. If the findings are viewed through this rhetoric it can be said that a poorer quality of play and the associated difficulties with coping could put PAE children's well-being at risk.

\subsubsection{Prenatal Alcohol Exposure and Social Play}

Research findings indicated that the prenatally exposed group had lower levels of playfulness on almost half of the items associated with social play when compared to the non-PAE group.

The social play items that the PAE group performed poorly on are discussed by reflecting on the meaning of the items as well as any comments that the raters made regarding the item scored. Research findings indicate that children with PAE had superficial interactions with other people during play as well as a lower level of social play. They also preferred to play alone rather than playing in a group. When scoring these items one rater commented that "only fighting was observed", whilst another stated that the 
participant "seldom interacted with those sitting with her". Findings also indicate that Children with PAE struggled to initiate a new activity with another player. Comments made with regards to this item, included that one participant only initiated play with others "once or twice"; another did so "rarely"; whilst yet another "really struggled to do this effectively". In addition, children with PAE struggled with the ease and cleverness with which they clowned or joked with friends.

These findings are supported by the literature that children with PAE are likely to experience problems with social behaviour (Carr, Agnihotri \& Keightley, 2010; Kelly, Day \& Streissguth, 2000; Kully-Martens et al., 2011; O'Connor et al, 2006; McGee et al., 2009; Streissguth et al., 1991). Problems with social behaviour are said to stem from the neurobehavioural deficits that have been associated with PAE, such as poor judgment and practical reasoning; inattention; hyperactivity; poor language performance; and problems with memory and executive functioning (Adnams et al., 2001; O’Connor et al., 2006).

The construct of playfulness has its roots in an occupational perspective of children's engagement, and as such cannot be interpreted by analysing separate performance components and skills (Bundy, 2010). Therefore links between the specific neurobehavioural deficits and social play behaviours observed by the Test of Playfulness cannot be drawn. However, a cautious link could be made between social playfulness and the broader social behavioural problems observed in children with PAE, such as problems understanding social cues, difficulty with flexibility and adaptability, indiscriminate social behaviour, and difficulty communicating in social contexts (Streissguth, 1997). Interestingly, understanding social cues can be observed during the Test of Playfulness. The current research found that although the PAE group had slightly lower mean scores for the item gives social cues (non-PAE $M=1.73 \mathrm{SD}=0.94$; $\mathrm{PAE} M=1.47 \mathrm{SD}=0.70$ ) and the item responds to social cues (non-PAE $M=1.80 \mathrm{SD}=0.80$; $\mathrm{PAE} M=1.53 \mathrm{SD}=0.52$ ) the difference was not significant for this population group $(p=0.45 ; p=0.37)$. As previously mentioned, flexibility informs both coping and playfulness 
scores, thus a further link between children with PAE's poor social behaviours and their poorer disposition to play socially could be drawn.

Children with PAE were found to be no different to children with no history of PAE in the ease with which they verbally or non-verbally asked for what they needed; the proportion of time in which they interacted with others involved in the same or similar activities; the ease with which they supported the play of others; the ease with which they did something to become part of a group; the ease with which they shared their toys or personal belongings; and their ability to give and respond to social cues.

When examining differences between the items that the groups scored differently on compared to the above items on which they scored similarly, the elements of playfulness that the items represent were investigated. The items related to social play are reflective of three of the four elements of playfulness: 'Internal Control'; 'Freedom to Suspend Reality'; and 'Framing'. Whilst results were both similar and significantly different for the social items representative of 'Internal Control', children with PAE scored significantly differently on the social items reflective of 'Freedom to Suspend Reality' when clowning or joking with others. A significant difference was not found on the items related to social play which falling under the 'Framing' element of playfulness. Therefore children with PAE could be said to struggle to alter their objective reality by stretching the rules through clowning or joking with others. However they were no different to their peers in their ability to understand and respond to the play frame being used.

\subsection{The fit of the Sample to the Existing Test of Playfulness Database} The sample had a total of $3.23 \%$ unexpected scorers (scores which did not conform to the ToP database). As this is within the five percent difference allowed by the Rasch Measurement Software, the sample can be said to fit the requirements of the ToP. 
Unexpected ratings on the Rasch Analysis occur when children score highly on items that are difficult or poorly on items that are easy (O'Brien \& Shirley, 2001). Unexpected scores can also be indicative of a group trait. Lower than expected scores occurred on Interacting with objects (Skill and Intensity); Safety (Extent); Engaged (Extent); Decides (Extent). These items reflect three of the four elements of the ToP: Interacting with objects (Skill and Intensity) forms part of 'Freedom to Suspend Reality'; Safety (Extent) and Decides (Extent) are representative of 'Internal Control'; and Engaged (Extent) falls under 'Intrinsic Motivation' (Skard \& Bundy, 2008).

Higher than expected scores occurred on Clowning/Joking (Extent and Skill); Mischief/Teasing (Extent); Unconventional (Extent); and Social Play (Intensity and Skill). In comparison to the lower than expected scores, these higher than expected scores predominantly reflected one element of playfulness. Clowning/Joking (Extent and Skill); Mischief/Teasing (Extent); and Unconventional (Extent) are items which all reflect 'Freedom to Suspend Reality' (Skard \& Bundy, 2008). This indicates that the children in the sample were more skilled than children in the ToP database at choosing how close to objective reality their play would be and in their ability to bend the rules slightly when teasing or joking. Social Play (Intensity and Skill) reflected one other element that was associated with higher than expected scores - that of 'Internal Control'.

The only element of playfulness not associated with any unexpected scores was 'Intrinsic Motivation'. This finding indicates that children in the sample were no different to children in the ToP database in their ability to engage in play because they wanted to, and not for any external reward (Skard \& Bundy, 2008). I.e. they found the doing to be more important than the outcome or product of play (Rubin, Fein \& Vandenberg, 1983).

Interestingly, when tests were performed to test the reliability of the items with the sample used, both 'Safety' and 'Interacting with Objects' were the only two items that had very low and even negative correlations with most 
other items. Further research is needed to determine whether these items should be removed when using the ToP with children playing in similar contexts to those in the sample.

\subsection{Environmental Impact on Playfulness}

When attempting to understand the unexpected scores relating to the item response validity, it became apparent that environment played a role in constraining or demanding different degrees of playfulness than would otherwise have been expected.

Langley (Langley, personal communication 2012, March 19) discusses that the schools and communities that constituted the sample all face daily problems with high levels of poverty, unemployment, and substance abuse. During an interview with one of the school principals, the researcher was informed that whenever playground equipment could be afforded and installed, it has been stolen or vandalised by members of the community. Thus none of the schools had any conventional western playground equipment (such as jungle gyms or climbing equipment). As noted in the researcher's observations (Appendix S), the playgrounds were predominantly empty, sandy pieces of land that ran alongside the school buildings. A few of the older girls were observed to play with a skipping rope and a few boys were observed to play with spinning tops or a ball they had brought with them from home. However, the vast majority of the children were observed to sit in groups on the outskirts of the grounds talking or eating, whilst others played a rough version of 'catchers' or play fighting.

Raters' comments next to the unexpectedly low 'Interaction with Objects' item included that two children were observed to have little opportunity to interact with toys, whilst one was observed to be unskilled when playing with a toy. Comments relating to the item 'Safety' were that one child was observed to be kicked or bullied, whilst another was observed to be "not always safe". The above observations, as well as the comments from the 
raters, could explain why the items 'Interaction with Objects' and 'Safety' were scored lower than expected.

Unexpected scores that relate to 'Clowns/Jokes' and 'Mischief/Teasing' could also be explained by considering the environment and age of the children. As discussed above, most of the children were observed either sitting in groups or playing catchers or play fighting. Playing catchers or play fighting with this population involves the children teasing each other to some extent during the chase. The girls sitting in groups could have also been observed to be clowning/joking with each other in their conversation or mannerisms. Future research could use the Test of Environmental Supportiveness (TOES) (Skard \& Bundy, 2008) to consider whether the environment lends itself more to these expressions of these play behaviours than would normally be expected. Children's personal motivations to engage in play are explored before the therapist begins to assess how each element (such as caregiver input, play space and friends) contributes to the attainment of their play motivations.

\subsection{The Role of the Occupational Therapist}

South Africa has the highest recorded prevalence rates of PAE in the world (South African Medical Research Council, 2008). Literature indicates that playfulness is a stable trait that is related to flexibility and coping in life (Skard \& Bundy, 2008). The Children with PAE in this study are more likely to have reduced abilities to cope with the socio-economic problems that are prevalent in their context and, failing intervention, could be at risk to continue the poverty and alcohol dependence cycles predominant in their communities (Peadon et al., 2008). These factors are thus likely to put PAE children's health and well-being at risk. Occupational therapists have a responsibility to ensure occupational justice (Townsend \& Wilcock, 2004), so that children with PAE who are found to have poorer playfulness scorers receive the interventions they require to enable them to engage in play that is culturally-defined and health-promoting. 
Occupational therapists are experts at assisting children with health conditions to play optimally (Bundy, 2008). Occupational therapists are also skilled at creating or adapting environments that support alternative ways of playing. Although playfulness is a stable trait that remains constant over time, studies have revealed that occupational therapy interventions can significantly improve the playfulness scores of both children with disabilities as well as typically developing children (Bundy et al., 2008; Brentall, Bundy \& Kay 2008; O’Brien \& Shirley, 2001; Okimoto, Bundy \& Hanzlik, 2007).

South Africa has a health care service in crisis and although policies provide a mandate for occupational therapy services to be made available to all citizens rehabilitation services still function as a luxury in many health, education, and community settings (Dayal, 2010; National Planning Commission, 2011). This begs the ethical question of where to position occupational therapy services in order to improve the playfulness of children with PAE.

Most of the occupational therapy interventions to improve playfulness that were reviewed in literature occurred during one-on-one interventions with the disabled child and his/her parent. However, one study used a broader environmental adaptation in which new and inexpensive play materials were positioned on a school playground as their method of intervention (Bundy et al., 2008). The study found significant improvements in children's playfulness. Considering the shortage of occupational therapists in rural contexts such as the Saldahna Bay Municipality, sustainable interventions aimed at environmental adaptation to improve children's playfulness could be considered. The ToP items which showed differences between the group those relating to social play - could be considered to guide the goals of the intervention within the school context. 


\subsection{Limitations of the Study}

\subsubsection{Study Design}

A descriptive analytical study design was used. Causality could therefore not be assumed.

\subsubsection{Sample Size}

A relatively small sample size of 30 participants limited the generalisability of the findings and increased the risk for Type I and II errors.

\subsubsection{Context in which Play was Observed}

Children were only filmed outdoors in their school playground. Although the Test of Playfulness does not require that children be filmed in both contexts, it is however preferred as it could potentially give a more thorough observation of the children's playfulness. Only observing children in one context could result in failing to identify children as playful when they could be playful in alternative contexts.

\subsubsection{Length of Video Footage}

Although each child should have been filmed for a total of 15 minutes each, this was not always possible within the school context. Break-times only lasted between 15-25 minutes and it was easy to lose sight of the child being filmed, as the large playgrounds were filled with many children who were all dressed similarly (due to their school uniforms). Although repeated attempts were made to film children who were more difficult to follow, approximately eight of the $30(26.67 \%)$ children were only filmed for between $12-15$ minutes. Observing the children for less time than is required by the ToP could result in scoring the children as playful or non-playful when the required amount of time might have proven them to be non-playful or playful. The reliability of the findings from the shorter films was therefore limited. 


\section{CHAPTER 6: CONCLUSION}

\subsection{Conclusion}

This study has described the playfulness of a small group of children with a positive history of prenatal alcohol exposure (PAE), who reside in a rural area in the Western Cape. A descriptive analytical design was used to compare the playfulness scores from a group of children with a positive history of PAE to a reference group.

The results of the study indicate that the PAE group had a significantly lower mean playfulness score than the non-PAE group. When compared to the Test of Playfulness (ToP) data set, it was revealed that the PAE group had a slightly lower mean playfulness score than the approximate mean of children with normal playfulness. The non-PAE group were shown to have a slightly higher mean playfulness score than the approximate mean playfulness score of the ToP data set. Furthermore, the PAE group was also found to have scored significantly lower on almost half of the items related to social play.

The results suggest that children with PAE are more likely to have a lowered disposition to play (playfulness) than their non-PAE counterparts. Children who are prenatally exposed to alcohol can therefore be considered to be more likely to experience a poorer quality of play and are more likely to struggle with some elements of social play than children not exposed to alcohol in utero. This is a new finding in the research on PAE, and is especially pertinent when considering the importance of play as a child's primary occupation and the knowledge that the prevalence of PAE in some areas of South Africa is estimated to be approximately 68 to 89 per 1000 (McKinsity, 2005).

Considering the shortage of occupational therapists in South Africa and the prevalence of PAE, occupational therapists are challenged to engage with creative and sustainable interventions that occur at the level of the 
environment and are best suited to help the majority of the individuals and communities living with PAE.

\subsection{Recommendations}

\subsubsection{For Therapists}

- South African therapists should acquaint themselves with the Test of Playfulness (ToP), as it is a quick and easy observational tool which is aligned to an occupational perspective of play.

- if not already familiar with screening for prenatal alcohol exposure, therapists should become familiar with screening questions and referral networks.

\subsubsection{For Future Research}

- future research could focus on using the ToP with the children in this sample in both indoor and outdoor environments at home and within the community, so as to determine whether differences in playfulness scorers exist in different contexts.

- the Test of Environmental Supportiveness (TOES) (Bundy \& Skard, 2008) could be performed at the school playgrounds to further investigate the impact of the environment on children's playfulness.

- the research study could be conducted with a greater sample size from a variety of different communities in South Africa, to evaluate whether the children with prenatal alcohol exposure score poorly on the same items in different contexts.

- future research could also take into consideration the number of siblings or cousins with whom participants' reside and the potential impact that they may have on participants' playfulness.

- future research could also allow for raters' to view and score the same tapes, to ensure higher levels of inter-rater reliability.

- future research could also include an intervention study to determine whether an occupational therapy intervention centred on adapting the play environment to improve PAE children's social play behaviours would make a difference to their playfulness scores. 


\section{REFERENCES}

Adnams, C., Kodituwakku, P., Hay, A., Molteno, C., Viljoen, D., \& May, P. 2001. Patterns of cognitive-motor development in children with Fetal Alcohol Syndrome from a community in South Africa. Alcoholism: Clinical and Experimental Research, 25(4):557-562.

Aragon, A., Kalberg, W., Buckley, D., Barela-Scott, L., Tabachnick, B., \& May, P. 2008. Neuropsychological study of FASD in a sample of American Indian children: processing simple versus complex information. Alcoholism: Clinical and Experimental Research, 32(12):2136-2148.

Astley, S., Bailey, D., Talbot, C., \& Clarren, S. 2000. Fetal Alcohol Syndrome (FAS) primary prevention through FAS diagnosis: II a comprehensive profile of 80 birth mothers of children with FAS. Alcohol and Alcoholism, 35(5):509-519.

Autti-Rumu, I. 2002. Foetal Alcohol Syndrome - a multi-faceted condition. Developmental Medicine \& Child Neurology, 44:141-144.

Bateson, G. 1972. Toward a theory of play and phantasy. In Steps to an ecology of the mind. G. Bateson, Ed. New York, NY: Wiley \& Sons. 14-20.

Belsky, J. \& Most, R. 1981. From exploration to play: a cross-sectional study of infant free play behaviour. Developmental Psychology, 17(5):630639.

Bergen, D. \& Fromberg, D. 2009. Play and social interaction in middle childhood. Phi Delta Kappan International, 426-430.

Bohjanen, S., Humphrey, M., \& Ryan, S. 2009. Left behind: lack of researchbased interventions for children and youth with Fetal Alcohol Spectrum Disorders. Rural Special Education Quarterly, 28(2):32-38. 
Brentnall, J., Bundy, A., \& Kay, F. 2008. The effect of the length of observation on test of playfulness scores. The Occupational Journal of Occupational Therapy Research: Occupation, Participation and Health, 28(3):133-140.

Bryze, K. 2008. Narrative contributions to the play history. In Play in occupational therapy for children. $2^{\text {nd }}$ ed. L. Parham \& L. Fazio, Eds. St Louis, MA: Mosley Elsevier. 43-54.

Bundy, A. 1997. Play and playfulness: what to look for. In Play in occupational therapy for children. $1^{\text {st }}$ ed. L. Parham \& L. Fazio, Eds. St Louis, MA: Mosby. 52-66.

Bundy, A. 2010. Evidence to practice commentary: beware of the traps of play assessment. Physical and Occupational Therapy in Pediatrics, 30(2):98-100.

Bundy, A., Luckett, T., Naughton, G, Tranter, P., Wyver, S., Ragen, J., Singletone, E., Spies, G. 2008. Playful interaction: occupational therapy for all children on the school playground. The American Journal of Occupational Therapy, 62(5):522-527.

Caillois, R. 1961. The definition of play and the classification of games. In The game design reader: a rule of play anthology. K. Salen \& E. Zimmerman, Eds. London: The MIT Press. 122-155.

Cameron, D., Leslie, M., Teplicky, R., Pollock, N., Stewart, D., Toal, C., \& Galk, S. 2001. The clinical utility of the ToP. The Canadian Journal of Occupational Therapy, 68(2):104-111.

Carr, J., Agnihotri, S., \& Keightley, M. 2010. Sensory processing and adaptive behavior deficits of children across the Fetal Alcohol Spectrum Disorder continuum. Alcoholism: Clinical and Experimental Research, 34(6):1022-1033.

Chandler, B. 1997. Introduction. In The essence of play: a child's occupation. B. Chandler, Ed. Bethesda, MD: The American Occupational Therapy Association. iii-iv. 
Chandrasena, A., Mukherjee, R., \& Turk, J. 2008. Fetal Alcohol Spectrum Disorders: an overview of interventions for affected individuals. Child and Adolescent Mental Health, 14(4):162-167.

Christiansen, C., Clark, F., Kielhofner, G., \& Rogers, J. 1995. Position paper: occupation. American Journal of Occupational Therapy, 49(10):10151018.

Chudley, A. 2008. Fetal Alcohol Spectrum Disorder: counting the invisible mission impossible? Archive of Disease in Childhood, 93(9):721-722.

Clark, C. \& Miller, P. 1998. Play. In Encyclopaedia of mental health. $4^{\text {th }}$ ed. H. Friedman, Ed. San Diego, CA: Academic Press. 189-197.

Cloete, L. 2005. Occupations of women who live and/or work in a rural farming community and who are at risk of having children with Foetal Alcohol Syndrome (FAS). Master's dissertation. University of Cape Town.

Coggins, T., Timler, G., \& Olswang, L. 2007. A state in double jeopardy: impact of Prenatal Alcohol Exposure and adverse environments on the social communicative abilities of school-age children with Fetal Alcohol Spectrum Disorder. Language, Speech, and Hearing Services in Schools, 38:117-127.

Coles, C. 2011. Discriminating the effects of prenatal alcohol exposure from other behavioural and learning disorders. Alcohol Research and Health, 34(1):42-50.

Cooper, R. 2000. The impact of child abuse on children's play: a conceptual model. Occupational Therapy International, 7(4):259-276.

Cordier, R., Bundy, A., Hocking, C., \& Einfeld, S. 2010. Comparison of the play of children with Attention Deficit Hyperactivity Disorder by subtypes. Australian Occupational Therapy Journal, 57:137-145.

Cornwell, D. \& Hobbs, S. 1985. The identification of play. Proceedings at the international symposium on "play, play therapy, play research". 12-14 
September 1985. Netherlands: Netherlands Organisation for Postgraduate Education in the Social Sciences. 2-7.

Creswell, J. 2003. Research design: qualitative, quantitative, and mixed methods approaches. $2^{\text {nd }}$ ed. Thousand Oaks, CA: Sage Publications.

Croxford, J. \& Viljoen, D. 1999. Alcohol consumption by pregnant woman in the western cape. South African Medical Journal, 89(9):958-965.

Dayal, H. 2010. Provision of rehabilitation services within the District Health System - the experience of rehabilitation managers in facilitating this right for people with disabilities. South African Journal of Occupational Therapy, 40(1):22-26.

Elgren, I., Bruaroy, S., \& Laegried, L. 2006. Lack of recognition and complexity of foetal alcohol neuroimpairments. Acta Paediatrica, 96:237-241.

Emsley, R. \& Seedat, S. 2008. Psychiatry in the southern African context: problems and challenges. In Primary health care psychiatry: a guide for southern Africa. Baumann, S., Ed. Kenwyn: JUTA. 38-45.

French, S. 1993. Practical research: a guide for therapists. Oxford: Butterworth-Heinemann.

Greenbaum, R., Stevens, S., Nash, K., Koren, G., \& Rovet, J. 2009. Social cognitive and emotional processing abilities of children with fetal alcohol spectrum disorders: a comparison with attention deficit hyperactivity disorder. Alcoholism: Clinical and Experimental Research, 33(10):1656-1670.

Greene, S. 1997. Playmates: social interaction in early and middle childhood. In The essence of play: a child's occupation. B. Chandler, Ed. Bethesda, MD: American Occupational Therapy Association. 131-157.

Hamm, E. 2006. Playfulness and the environmental support of play in children with and without developmental disabilities. The Occupational 
Therapy Journal of Research: Occupation, Participation and Health, 26(3):88-96.

Henry, A. 2008. Assessment of play and leisure in children and adolescents. In Play in occupational therapy for children. $2^{\text {nd }}$ ed. L. Parham \& L. Fazio, Eds. St Louis, MO: Mosley Elsevier. 95-191.

Hess, L. \& Bundy, A. 2003. The association between playfulness and coping in adolescents. Physical and Occupational Therapy in Paediatrics, 23(2):5-17.

Hicks, C. 2009. Research methods for clinical therapists: applied project design and analysis. Edinburgh: Churchill Livingston Elsevier.

Hoyme, H., May, P., Kalberg, W., Kodituwakku, P., Gossage, P., Trujillo, P., Buckly, D., Miller, J. et al. 2004. A practical clinical approach to diagnosis of Fetal Alcohol Spectrum Disorders: clarification on the 1996 Institute of Medicine Criteria. Pediatrics, 115(1):39-47.

Jackson, S. 2009. Research methods and statistics: a critical thinking approach. $3^{\text {rd }}$ ed. Belmont: Wadsworth, Cengage Learning.

Jacobson, S., Jacobson, J., Sokol, R., Martier, S., \& Ager, J. 1993. Prenatal Alcohol Exposure and infant information processing ability. Child Development, 64:1706-1721.

Johnson, B. 2001. Toward a new classification of nonexperimental quantitative research. Educational Researcher, 30(1):2-33.

Kalberg, W., Provost, B., Tollison, S., Tabachnick, B., Robinson, L., Hoyme, E., Trujillo, P., Buckley, D. et al. 2006. Comparison of motor delays in young children with Fetal Alcohol Syndrome to those with Prenatal Alcohol Exposure and with no Prenatal Alcohol Exposure. Alcoholism: Clinical and Experimental Research, 30(12):2037-2045.

Kelly, S., Day, N., \& Streissguth, A. 2000. Effects of Prenatal Alcohol Exposure on social behaviour in humans and other species. Neurotoxicology and Teratology, 22(2):143-149. 
Knox, S. 2008. Development and current use of the revised Knox Preschool Play Scale. In Play in occupational therapy for children. $2^{\text {nd }}$ ed. L. Parham \& L. Fazio, Eds. St Louis, MO: Mosley Elsevier. 95-191.

Kuhaneck, H., Spitzer, S., \& Miller, E. 2010. Activity analysis, creativity, and playfulness in pediatric occupational therapy: making play just right. Sudbury, MA: Jones and Barlett Publishers.

Kully-Martens, K., Denys, K., Treit, S., Tamana, S., \& Rasmussen, C. 2012. A review of social skills deficits in individuals with Fetal Alcohol Spectrum Disorders and Prenatal Alcohol Exposure: profiles, mechanisms, and interventions. Alcoholism: Clinical and Experimental Research, 36(4):568-576.

Lawrence, R., Bonner, H., Newsom, R., \& Kelly, S. 2008. Effects of alcohol exposure during development on play behaviour and c-Fos expression in response to play behaviour. Behavioural Brain Research, 188(1):209-218.

London, L., Sanders, D., \& Naude, J. 1998. Farm workers in South Africa the challenge of eradicating alcohol abuse and the legacy of the 'DOP' system. South African Medical Journal, 88(9):1092-1904.

Lupton, C., Burd, L., \& Harwood, R. 2004. Cost of fetal alcohol spectrum disorders. American Journal of Medical Genetics, 127(C):42-50.

May, P., Gossage, J., Marias, A-S., Hendricks, S., Cudore, L., Snell, B., Tabachnick, C., Stellavato, C., et al. 2008. Maternal risk factors for Fetal Alcohol Syndrome and partial Fetal Alcohol Syndrome in South Africa. Alcoholism: Clinical \& Experimental Research, 32(5):738-736.

May, P., Gossage, P., Kalberg, W., Robinson, L., Buckley, D., Manning, M., \& Hoyme, E. 2009. Prevalence and epidemiologic characteristics of FASD from various research methods with an emphasis on recent inschool studies. Developmental Disabilities Research Reviews, 15:176-192. 
McGee, C., Bjorkquist, O., Price, J., Mattson, S., \& Riley, E. 2009. Social information processing skills in children with histories of heavy Prenatal Alcohol Exposure. Journal of Abnormal Child Psychology, $37: 817-830$.

McKinstry, J. 2005. Using the past to step forward: Fetal Alcohol Syndrome in the Western Cape Province of South Africa. American Journal of Public Health, 95(7):1097-1099.

Miller, M. \& Spear, L. 2006. The alcoholism generator. Alcoholism: Clinical and Experimental Research, 30(9):1466-1469.

Molteno, C., Jacobson, S., Carter, R., \& Jacobson, J. 2010. Infant symbolic play as an early indicator of fetal alcohol-related deficit. The Official Journal of the International Society on Infant Studies, 15(6):586-607.

Murthy, P., Kudlur, S., George, S., \& Mathew, G. 2009. A clinical overview of Fetal Alcohol Syndrome. Addictive Disorders \& Their Treatment, $8(1): 1-12$.

Muys, V., Rodger, S., \& Bundy, A. 2006. Assessment of playfulness in children with Autistic Disorder: a comparison of the children's playfulness scale and the test of playfulness. Occupational Therapy Journal of Research: Occupation, Participation and Health, 26(4):159170.

National Planning Commission. 2011. Diagnostic overview. Pretoria: Department of the Presidency.

Neumann, E. 1971. The elements of play. New York, NY: MSS Information.

O'Brien, J. \& Shirley, R. 2001. Does playfulness change over time? A preliminary look using the test of playfulness. The Occupational Therapy Journal of Research, 21(2):132-140.

O'Connor, M., Frankel, F., Paley, B., Schonfeld, A., Carpenter, E., Laugeson, E., \& Marquardt, R. 2006. A controlled social skills training for children 
with Fetal Alcohol Spectrum Disorders. Journal of Counselling and Clinical Psychology, 74(4):639-648.

Okimoto, A., Bundy, A., \& Hanzik, J. 2000. Playfulness in children with and without disability: measurement and intervention. American Journal of Occupational Therapy, 54(1):73-82.

O'Leary, C. Nassar, N., Kurinczuk, J., \& Bower, C. 2008. The effect of maternal alcohol consumption on fetal growth and preterm birth. British Journal of Obstetrics and Gynaecology, 116:390-400.

Oxford Dictionaries Online. 2012. Coloured. Oxford University Press. Available:

http://www.oxforddictionaries.com/definitions/english/coloured [2012, August 22].

Parham, L. 2008. Play and occupational therapy. In Play in occupational therapy for children. $2^{\text {nd }}$ ed. L. Parham \& L. Fazio, E:ds. ST Louis, MO: Mosley Elsevier. 3-39.

Peadon, E., Fremantle, E., Bower, C., \& Elliot, E. 2008. International survey of diagnostic services for children with Fetal Alcohol Spectrum Disorders. BioMed Central Pediatrics, 8(12):1471-1479.

Peterson, I., Swartz, L., Bhana, A., \& Flisher, A. 2010. Mental health promotion initiatives for children and youth in contexts of poverty: the case of South Africa. Health Promotion International, 25(3):331-341.

Pienaar, M. \& Molteno, C. 2010. A self psychology perspective on the formulation and treatment of psychopathology in children with Foetal Alcohol Spectrum Disorders. Psychoanalytic Psychotherapy in South Africa, 18(1):58-80.

Ramugondo, E. 2005. Play and playfulness: children living with HIV/AIDS. In Transformation through occupation. R. Watson, \& L. Swartz, Eds. London: Whurr Publishers. 171-185. 
Rasmussen, C., Pei, J., Manji, S., Loomes, C., \& Andrew, G. 2009. Memory strategy development in children with Foetal Alcohol Spectrum Disorders. Developmental Neurorehabilitation, 12(4):207-214.

Reid, D. 2004. The influence of virtual reality on playfulness in children with Cerebral Palsy: a pilot study. Occupational Therapy International, 11(3):131-144.

Rendall-Mkosi, K., London, L., Adnams, C., Morojele, N., McLoughlin, J-A., \& Goldstone, C. 2008. Fetal Alcohol Spectrum in South Africa: situational and gap analysis. Pretoria: United Nations Children's Fund South Africa, Medical Research Council, University of Cape Town, and University of Pretoria.

Royeen, C. 1997. Play as occupation and as an indicator of health. In the essence of play: a child's occupation. B. Chandler, Ed. Bethesda, MD: American Occupational Therapy Association. 1-16.

Rubin, K., Fein, G., \& Vandenberg, B. 1983. Play. In Handbook of child psychology. P. Mussen, Ed. New York, NY: Wiley.

Saldanha Bay Municipality. Integrated development plan 2006 - 2011. 2007. Available:

http://www.capegateway.gov.za/eng/your_gov/12350/pubs/plans/ [2011, August 1].

Schlesselman, J. 1982. Case-control studies: design, conduct, analysis. USA: Oxford University Press.

Skard, G. \& Bundy, A. 2008. Test of playfulness. In Play in occupational therapy for children. $2^{\text {nd }}$ ed. L. Parham \& L. Fazio, Eds. St. Louis, MO: Mosley Elsevier. 71-93.

SAS Institute. 2012. JMP 10 basic analysis and graphing. Cary, NC: SAS Institute. 
Smith, P. \& Vollstedt, R. 1985. On defining play: an empirical study if the relationship between play and various play criteria. Child Development, 56:1042-1050.

Sood, B., Delaney-Black, V., Covington, C., Nordstrom-Klee, J., Ager, J., Templin, T., Janisse, J., Martier, S. et al. 2001. Prenatal Alcohol Exposure and childhood behaviour at age 6 to 7 years: i. doseresponse effect. Pediatrics, 108(2):33-42.

South African Medical Research Council. 2008. Fetal Alcohol Spectrum Disorders in Cape town, South Africa: a huge challenge requiring multi-faceted prevention strategies. (Policy Brief). Available: www.mrc.ac.za/policybriefs/FetalAlcoholSpectrum.pfd [2011, March 7].

Stagnitti, K. 2004. Understanding play: the implications for play assessment. Australian Occupational Therapy Journal, 51:3-5.

Steinhaussen, H., Willms, J., Metzke, C., \& Spohr, H. 2003. Behavioural phenotype in Foetal Alcohol Syndrome and Foetal Alcohol Effects. Developmental Medicine and Child Neurology, 45:179-182.

Streissguth, A., Aase, J., Clarren, S., Randels, S., LaDue, R., \& Smith, D. 1991. Fetal Alcohol Syndrome in adolescents and adults. The Journal of the American Medical Association, 265(15):1961-1967.

Stuart, E. \& Rubin, D. 2008. Best practices in quasi-experimental designs: matching methods for causal inference. In Best practices in quantitative methods. J. Osborne, Ed. Thousand Oaks, CA: Sage Publications. 155-176.

Sutton-Smith, B. 1997. The ambiguity of play. Cambridge: Harvard University Press.

Townsend, E. \& Wilcock, A. 2004. Occupational justice and client-centred practice: a dialogue in progress. Canadian Journal of Occupational Therapy, 71(2):75-87. 
University of Cape Town. 2009. Research involving children: standard operating procedures. Available:

http://www.health.uct.ac.za/research/humanethics/sop [2012, August 21].

University of Cape Town. 2011. Occupational therapy: about us. Available: http://www.health.uct.ac.za/departments/shrs/occupational/about/ [2011, October 31].

Urban, M., Chersich, M., Fourie, L-A., Chetty, C., Olivier, L., \& Viljoen, D. 2008. Fetal Alcohol Syndrome among Grade 1 schoolchildren in Northern Cape Province: prevalence and risk factors. South African Medical Journal, 98(1):877-882.

Watson, R. \& Fourie, M. 2005. Occupation and occupational therapy. In Transformation through Occupation. R. Watson, \& L. Swartz, Eds. London: Whurr Publishers. 19-32.

Wolberg, P. 2003. Peer play and the Autism Spectrum: the art of guiding children's socialization and imagination. Kansas: Autism Asperger Publishing.

Woods, D. 2002. Birth defects manual. Cape Town: Perinatal Education Trust.

World Medical Association. 2008. Declaration of Helsinki: ethical principles for medical research involving human subjects. Available: http://www.health.uct.ac.za/research/humanethics/links [2012, August 21].

Wright, B. \& Masters, G. 1982. Rating scale analysis: Rasch measurement. Chicago, IL: Mesa Press. 


\section{APPENDICES}

\section{Appendix A: Ethics Approval}

\section{UNIVERSITY OF CAPE TOWN}

\section{Health Sciences Faculty \\ Human Research Ethics Committee \\ Room E52-24 Groote Schuur Hospital Old Main Building \\ Observatory 7925}

Telephone [021] 4066338 • Facsimile [021] 4066411

e-mail: shuretta.thomas@uct.ac.za

11 November 2011

HREC REF: $532 / 2011$

Ms J Pearton

c/o Dr E Ramugondo

Occupational Therapy

Health \& Rehab

$\mathrm{OMB}$

Dear Ms Pearton

\section{PROJECT TITLE: PLAYFULNESS AND PRE-NATAL EXPOSURE TO ALCOHOL: A COMPARATIVE STUDY.}

Thank you for submitting your study to the Faculty of Health Sciences Human Research Ethics Committet for review.

It is a pleasure to inform you that the HREC has formally approved the above-mentioned study.

Approval is granted for one year till the 28 November 2012.

Please submit a progress form, using the standardised Annual Report Form (FHS016), if the study continues beyond the approval period. Please submit a Standard Closure form (FHS010) if the study is completed withir the approval period.

Please note that the ongoing ethical conduct of the study remains the responsibility of the principa investigator.

Please quote the HREC. REF in all your correspondence.

Yours sincetely

PROFESSOR M BLOGKMAN

MHAIRPERSON, HSF HUMAN ETHICS

tral Wide Assurance Number: FWA00001637.

ational Review Board (IRB) number: IRB00001938 


\title{
Appendix B: Letter to the Western Cape Education Department
}

\author{
University of Cape Town \\ Occupational Therapy Department \\ Masters Thesis
}

Permission to conduct research

Dear Dr Wyngaard,

I am a Masters student in occupational therapy, currently conducting my research project through the University of Cape Town. The purpose of the study involves exploring the relationship between the effects of drinking alcohol during pregnancy and children's play.

I am requesting permission to conduct my study at primary schools in the Saldana Bay municipality, during the time frame of February - May 2012. The study will involve video-recording thirty grade one participants once (for 15 minutes) whilst they play during their normal break time on the school's playground. The recording will then be assessed by qualified occupational therapists using the Test of Playfulness (ToP).

All ethical guidelines and procedures will be followed, including asking permission from the school's principals and seeking parental consent and learner assent. The names and details of the participants will be changed to ensure confidentiality. The school's name and details will not be mentioned in the write-up of the report, in order to ensure confidentiality. The videotapes will be destroyed following assessment. Test results shall be discussed with the parents/guardians in detail and referrals to the relevant resources 
will be provided should a need for further assessment and treatment be indicated.

Please do not hesitate to contact me should you have any queries.

Thank you in anticipation.

Regards,

Jordan Pearton

Occupational Therapist

Email address: jordanpearton@yahoo.com

Cell phone no.: 0829528051 


\section{Appendix C: Permission from the Western Cape Education Department}

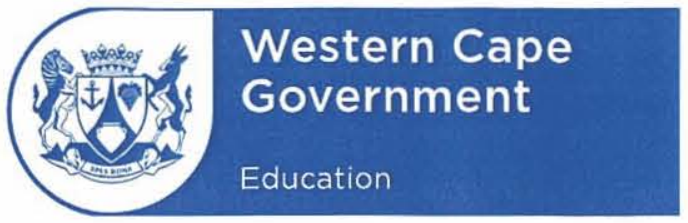

REFERENCE: 20120104-0014 ENQUIRIES: Dr A T Wyngaard Ms Jordan Pearton

School of Health and Rehabilitation Sciences Division of Occupational Therapy UCT

\author{
Directorate: Research \\ Audrey.wyngaard2@pgwc.gov.za \\ tel: +270214769272 \\ Fax: 0865902282 \\ Private Bag x9114, Cape Town, 8000 \\ wced.wcape.gov.za
}

\section{Dear Ms Jordan Pearton}

RESEARCH PROPOSAL: PLAYFULNESS AND PRE-NATAL ALCHOHOL EXPOSURE: A COMPARATIVE STUDY

Your application to conduct the above-mentioned research in schools in the Western Cape has been approved subject to the following conditions:

1. Principals, educators and learners are under no obligation to assist you in your investigation.

2. Principals, educators, learners and schools should not be identifiable in any way from the results of the investigation.

3. You make all the arrangements concerning your investigation.

4. Approval for projects should be confirmed by the District Director of the schools where the project will be conducted.

5. Educators' programmes are not to be interrupted.

6. The Study is to be conducted from 16 January 2012 till 28 June 2012

7. No research can be conducted during the fourth term as schools are preparing and finalizing syllabi for examinations (October to December).

8. Should you wish to extend the period of your survey, please contact Dr A.T Wyngaard at the contact numbers above quoting the reference number?

9. A photocopy of this letter is submitted to the principal where the intended research is to be conducted.

10. Your research will be limited to the list of schools as forwarded to the Western Cape Education Department.

11. A brief summary of the content, findings and recommendations is provided to the Director: Research Services.

12. The Department receives a copy of the completed report/dissertation/thesis addressed to: The Director; Research Services; Western Cape Education Department; Private Bag X9114; CAPE TOWN; 8000.

We wish you success in your research.

Kind regards.

Signed: Dr Audrey T Wyngaard

for: HEAD: EDUCATION

DATE: 23 March 2012

Lower Parliament Street, Cape Town, 8001

tel: +27 214672000 fax: +27214672996

Safe Schools: 0800454647
Private Bag X9114, Cape Town, 8000

Employment and salary enquiries: 0861923322

www.westerncape.gov.za 


\title{
Appendix D: Letter to the School Principal
}

\author{
University of Cape Town \\ Occupational Therapy Department \\ Masters Thesis
}

Permission to conduct research

Dear Principal,

I am a Masters student in occupational therapy, currently conducting my research project through the University of Cape Town. The purpose of the study is to explore the relationship between the effects of drinking alcohol during pregnancy and children's play.

Permission to initiate the study and contact you has been provided by the University of Cape Town's Ethics Committee as well as from the Directorate of Research at the Western Cape Education Department (please refer to the attachments for copies of these permission forms). I would like to ask for your permission to perform my research study at your school, during the time frame of March - May 2012. The study will involve video-recording thirty grade one participants once (for 15 minutes) whilst they play during their normal break time on the school's playground. The recording will then be assessed by qualified occupational therapists using the Test of Playfulness (ToP).

All ethical guidelines and procedures will be followed, including gaining parental consent and learner assent. The names and details of the participants will be changed to ensure confidentiality. Your school's name and details will not be mentioned in the write-up of the report, in order to 
ensure the participants confidentiality. The video-tapes will be destroyed following assessment. Test results shall be discussed with the parents/guardians in detail and referrals to the relevant resources will be provided should a need for further assessment and treatment be indicated.

Children's participation in the project is voluntary, and they have the right to refuse to join in or withdraw at anytime during the research study.

Please do not hesitate to contact me should you have any queries.

Thank you in anticipation.

Regards,

Jordan Pearton

Occupational Therapist

Email address: jordanpearton@yahoo.com

Cell phone no.: 0829528051 


\title{
Appendix E: Information Letter (English)
}

\author{
University of Cape Town \\ Occupational Therapy Department \\ Masters Thesis: \\ Playfulness and Pre-natal Exposure to Alcohol: A Comparative Study
}

Information Sheet

Dear Parent/Guardian,

I am a Masters student in occupational therapy at the University of Cape Town (UCT). As part of my degree I will be doing research to explore if children whose mothers drank alcohol when they were pregnant with them, play differently to children whose mothers did not drink alcohol when they were pregnant with them.

The research will include video-recording all the children in the research study once (for 15 minutes) while they play during break-time on the school's playground. The children who will be part of the research will be children whose mothers drank alcohol when they were pregnant with them, as well as children whose mothers did not drink alcohol when they were pregnant with them. All of the video's will then be looked at and assessed by qualified occupational therapists using the Test of Playfulness (ToP).

If you would like for your child to be part of the research, you will first need to agree to be phoned so that we can organise having a short interview with me at your child's school. In the interview I will give you more information about the research and ask you a few questions about your child. Together we can decide if your child can take part in the research. After the interview, and only 
if you first allow your child to be part of the research, I will ask your child if he/she wants to be a part of the research, before beginning the research.

When I write up the research results I will change the names and details of the children so that no one (except the myself) will know who he/she is. Although some people will see me having interviews with parents and videorecording some children during break-time, I will have children whose mothers drank alcohol during pregnancy as well as children whose mothers did not drink alcohol in the research, so that no one (except for myself) will know which children belong to which group. However, as a health practitioner I am obliged by law to report any instance of abuse that I may come across during my research, to the relevant authorities.

The video-tapes will be destroyed after the research is finished. The children will be video-taped during their normal everyday play during break-time at school. I will not at anytime tell the children how they should be playing. If a child gets hurt while they are being videoed I will tell the appropriate adults at the school, but any injury will not be the fault of myself or UCT. Children are allowed to decide if they want to take part in the research or not. You and your child have the right to say no to taking part in the research or stopping being a part of the research at anytime.

If your child takes part in the study, we will have a meeting after getting the results back to talk about their results. If your child then needs any more tests or treatment, I will referral you to other occupational therapists and professionals who can help your child.

Please phone me at anytime if you have any questions. Thank you!

Regards, 
Jordan Pearton

Occupational Therapist

Cell phone no.: 0829528051 


\section{Appendix F: Information Letter (Afrikaans)}

\section{Universiteit van Kaapstad}

Departement Arbeidsterapie

Meesters-tesis:

\section{Playfulness and Pre-natal Exposure to Alcohol: A Comparative Study}

\section{Informasie-blad}

Liewe Ouer/Voog,

Ek is ' $\mathrm{n}$ meesters-student in arbeidsterapie by die Universiteit van Kaapstad (UK). As deel van my graad, gaan ek navorsing doen om te verken of kinders wie se moeders alkohol gedrink het tydens hulle swangerskap anders speel in vergelyking met kinders wie se moeders nie alkohol gedrink het tydens hulle swangerskap nie.

Die navorsing sal video-opnames (van sowat 15 minute) van al die kinders in die navorsings-studie insluit, terwyl die kinders speel gedurende pouse op die skool se speelgronde. Die kinders wie deel sal vorm van die navorsing sal kinders insluit wie se moeders alkohol gedrink het tydens hulle swangerskap en kinders wie se moeders nie alkohol gedrink het tydens hulle swangerskap nie. Die video-opnames sal dan deur gekwalifiseerde arbeidsterapeute bestudeer en evalueer word deur om gebruik te maak van die "Test of Playfulness" (ToP).

As $u$ belang stel om $u$ kind deel te maak van die navorsing, sal $u$ toestemming moet gee sodat ons $u$ kan skakel om ' $n$ afspraak te reël by $u$ kind se skool om ' $n$ kort onderhoud met $u$ te voer. In hierdie onderhoud, sal ek vir u meer inligting verskaf rondom die navorsing en vir u ' $n$ paar vrae vra 
aangaande $u$ kind. Saam kan ons besluit of $u$ kind deel kan wees van die navorsing. Na die onderhoud, en as $u$ toestemming gee vir $u$ kind om deel te wees van die navorsing, sal ons vir u kind vra of hy/sy deel wil wees van die navorsing, voordat ons begin met die navorsing.

Wanneer ek die navorsingsresulte dokumenteer, sal ek die name en besonderhede van die kinders verander, sodat niemand (behalwe ek) u kind sal kan identifiseer nie. Alhoewel sommige mense my sal sien terwyl ek onderhoude voer met ouers en terwyl ek sekere kinders afneem tydens video-opnames tydens pouses, sal ek gebruik maak van kinders wie se moeders alkohol gedrink het tydens hulle swangerskap en kinders wie se moeders nie alkohol gedrink het tydens hulle swangerskap nie. Sodoende, sal niemand (behalwe ek) weet aan watter groep die kinders behoort nie. As 'n gesondheids-praktisyn, word ek deur die wet verplig om enige teken van mishandeling te rapporteer aan die relevante owerhede, indien ek daarop afkom tydens my navorsing.

Die video-opnames sal vernietig word aan die einde van die navorsing. Die kinders sal opgeneem word by die skool, tydens hulle allerdaagse speeltyd gedurende pouse. Ek sal onder geen omstandighede vir die kinders vertel hoe om te speel nie. As ' $n$ kind beseer word terwyl die video-opnames gemaak word, sal ek die relevante volwassenes by die skool inlig, maar geen besering sal vir my of UK as die skuldige party aanwys nie. Kinders het vrye keuse om te besluit of hulle wil deel wees van die navorsing of nie. $U$ en $u$ kind het die reg om nie deel te wees van die navorsing nie en kan ook enige tyd besluit om te ontrek uit die navorsing.

As $u$ kind deelneem aan die navorsing, sal ons ' $n$ vergadering hou na die resultate gefinaliseer is, om te praat oor die resultate. Indien u kind gevolglik nog toetse of behandeling nodig het, sal ek $u$ verwys na ander arbeidsterapeute en professionele mense wie u kind sal kan help. 
Skakel my asseblief enige tyd indien u enige navrae het. Baie dankie!

Groete,

Jordan Pearton

Arbeidsterapeut

Selfoon no.: 0829528051 


\title{
Appendix G: Information Letter (Xhosa)
}

\author{
lyunivesithi yaseKapa
}

Icandelo looNompilo

IThisi yesidanga seMastas zobuNompilo

\section{Ukuthanda ukudlala nokungakhuseleki etywaleni phambi kokuzalwa Izifundo zokuthelekisa}

\author{
Iphepha lenkcukacha
}

Mzali/ Mlondolozi

Ndingumfundi wesidanga seMastas zobuNompilo kwiYunivesithi yaseKapa(UCT). Njengenxalenye yobuchule bomsebenzi wam, ndiza kwenza uphando ukuhlola ukuba abantwana abanomama ebebesela utywala ngelixa bebekhulelwe, bona badlala ngokwahlukeneyo na kunaba abanomama ebebengaseli tywala ngelixa bekhulelwe bona.

Olu phando luza kuquka, ushicilelo Iwetape ye T.V. Iwabo bonke abantwana kwisifundo solu phando kanye (Iwemizuzu eli 15) xa bedlala ngexesha lekhefu kumabala emidlalo. Abantwana abaza kuba yinxalenye yophando, ngabanabazali ebebesela utywala ngelixa bekhulelwe bona nabanabazali ebebengaseli tywala ngelixa bekhulelwe bona. Zonke ezi tape zeT.V, ziza kuqwalaselwa yaye zihlolwe ngooNompilo abaqinisekisiweyo, bebenzisa itesti/ uvavanyo IweZemidlalo(ToP).

Ukuba ufuna umntwana wakho abe yinxalenye yolu phando, kuqala kufuneka uvume ukufonelwa ukuze silungisele ukuba ube nodliwano-ndlebe olufutshane nam esikolweni somntwana. Kudliwano-ndlebe ndiza kunika ulwazi oluthe vetshe ngophando yaye ndikubuze nemibuzo embalwa 
ngomntwana. Sobabini siza kugqiba ukuba umntwana wakho abe yinxalenye yophando. Emva kodliwano-ndlebe, naxa kuqala uvuma ukuba umntwana wakho abe yinxalenye yophando, ndiza kubuza ukuba umntwana uyafuna na ukuba yinxalenye yophando, phambi kokuqala uphando.

Xa ndibhala ngeziphumo zophando ndiza kutshintsha amagama neenkcukacha zabantwana ukuze kungabikho bani (ngaphandle kwam) oza kwazi ukuba ngubani yena. Nangona abanye abantu beza kundibona ndino dliwano-ndlebe Iwe tape yeT,V, nabazali noshicilelo Iwabanye abantwana ngexesha lekhefu esikolweni, ndiza kuba nabantwana babazali ebebesela utywala ngelixa bebekhulelwe bona nabebengaseli tywala kuphando ukuze kungabikho bani (ngaphandle kwam) waziyo ukuba ngabaphi abantwana abaphantsi kweliphi iqela. NjengoGqirha(Nompilo), ndigunyazisa ngumthetho ngengxelo yawo nawuphi na umzekeko wempatho-mbi endinokuhlangabezana nayo ngelixa lophando kubaphathi abanxulumene nam.

Ushicilelo Iwetape yeT.V. luya kucinywa emva kokugqitywa kophando. Abantwana bayakushicilelwa ngexesha labo lesiqhelo lokudlala, ngexesha lekhefu esikolweni. Andinakho naninina ukubaxelela ukuba badlale njani? Ukuba umntwana wenzakele xa beshicilelwa, ndiza kuxelela abantu abadala abafenele oko esikolweni, kodwa nawuphi umonzakalo awuzi kuba yingxaki/ sisiphoso sam okanye se U.C.T. Abantwana bavumelekile bathathe isigqibo/ bagqibe ukuba bafuna ukuba yimxalenye yophando okanye hayi. Wena nomntwana ninelungelo lokuthi hayi ukuthatha inxaxheba kuphando okanye uyeke ukuba yinxalenye nanini na.

Ukuba umntwana wakho unenxaxheba kwesi sifundo, siza kuba nentlanganiso emva kokufumana iziphumo sithethe ngeziphumo zabo. Ukuba umntwana wakho ngoko ufuna ezinye iitest/uvavanyo okanye unyango, ndiza kukuthumela kwabanye ooNompilo nabanye abavunyiweyo. 
Ndicela undifonele nanini xa unemibuzo. Enkosi!

Imibuliso:

Jordan Pearton

UNompilo

Inombolo yeseli : 0829528051 
Appendix H: Consent to be contacted sheet (English)

University of Cape Town

Occupational Therapy Department

Masters thesis

Consent to be contacted sheet

I

(parent/guardian's name) have $\mathrm{read} /$ have had read to me the accompanying information sheet about the research and agree that the researcher can phone me to organise an interview.

Parent/Guardian's name:

Telephone number:

The hours when the researcher can phone you:

Signed:

Parent/Guardian

Date and Place 


\section{Appendix I: Consent to be contacted sheet (Afrikaans)}

Universiteit van Kaapstad

Departement Arbeidsterapie

Meesters-tesis

Toestemmingvorm om gekontak te word

Ek

(ouer/voog se naam) het die bygaende informasie-blad gelees / vir my laat lees omtrent the navorsing en gee die navorser toestemming om my te skakel om ' $n$ onderhoud te reël.

Ouer/Voog se naam:

Telefoon nommer:

Die ure waartydens die navorser mag skakel:

Geteken:

Ouer/Voog

Datum 
Appendix J: Consent to be contacted sheet (Xhosa)

\author{
Iyunivesithi yaseKapa \\ Icandelo looNompilo
}

IThisisi yeMastas

Iphepha mvume onokudibana nalo

Mna

(igama lomzali/lomlondolozi)

ndilifundile/ ndilifundelwe nenkcukacha ezihamba nalo iphepha ngophando yaye ndiyavuma ukuba umphandi angandifonela alungiselele udliwanondlebe.

Igama lomzali/ lomlondolozi:

Inombolo yefoni:

lyure ekunokufonwa ngazo ngumphandi:

Ityikitywe/ Isityikityo:

Umzali/ Umlondolozi

Umhla: 


\title{
Appendix K: Informed Consent Sheet (English)
}

\author{
University of Cape Town \\ Occupational Therapy Department \\ Masters thesis
}

Informed Consent Sheet

I _— (parent/guardian's name) agree for my child to be part of the study conducted by the University of Cape Town, Occupational Therapy masters student, Miss J. Pearton.

I have read/or have had read to me, the accompanying information sheet detailing the study. I understand the purpose of the study and that I may withdraw my child's participation or information at any time.

Signed:

Parent/Guardian

Date and Place 


\title{
Appendix L: Informed Consent Sheet (Afrikaans)
}

\author{
Universiteit van Kaapstad \\ Departement Arbeidsterapie \\ Meesters-tesis
}

Ingeligte Toestemmingvorm

Ek

(ouer/voog se name) gee

toestemming vir my kind om deel te wees van die navorsing wat gelei word deur Mej. J. Pearton, 'n arbeisterapeut meesters-student te Universiteit van Kaapstad.

Ek het die bygaende informasie-blad gelees / vir my laat lees wat die navorsing beskryf. Ek vestaan die doel van die navorsing en dat ek enige tyd my kind, of informasie, mag ontrek uit die navorsing.

Geteken:

Ouer/Voog

Datum en plek 
Appendix M: Informed Consent Sheet (Xhosa)

Iyuniversitithi yaseKapa

Icandelo looNompilo

IThisisi yeMasta

Iphepha lesiqinisekiso elivunyiweyo

Mna

(mzali/mmeli igama lam) ndiyavuma

ukuba umtwana wam abe yinxalenye yesifundo esenziwa ngu Nkosazana J. Peartin, uNompilo osengumfundi weMastas kwi Universithi yaseKapa.

Ndifundile/ndifundelwe, iphepha elihamba nolwazi neenkcukacha zesifundo. Ndiyayiqonda injongo yesi sifundo yaye ndigarhoxa ukuthatha inxaxheba naninina.

Ityikitywe

Umzali/Ummeli

Ixesha ne Ndawo 


\section{Appendix N: Participants Background Information}

\section{PERSONAL PARTICULARS}

Surname

Name

Name of Primary Carer

Date of Birth

Gender

Languages

Address (Street)

Telephone (Home)

(Work)

(Cell phone)

\section{BIRTH HISTORY}

Pregnancy: Mother's health

Smoking or drug use during pregnancy

amount

duration

type

Alcohol use during pregnancy

amount

duration

type

Gestation: born at

weeks (or

months)

Born at (hospital / clinic / home)

Labour: spontaneous induced duration

Delivery: Normal

Forceps Caesarean (planned)

Emergency

Post Natal: was the child in ICU? Yes No duration was the child in an incubator? Yes No duration

Comments 
MEDICAL HISTORY

General Health:

Medication:

Epilepsy / Convulsions:

Medical Investigations / Surgery:

Dr Appointments:

Therapy Appointments:

Comments:

\section{EARLY CHILDHOOD DEVELOPMENT}

Sitting:

Crawling:

Walking:

Toilet training:

Single words:

Sentences:

Play: Independent / Free play

Play with siblings / friends

Play with care-giver

Social behaviour:

Achievements / struggles at preschool:

Comments:

\section{PARENT / CARER FEEDBACK}

Does the carer have any concerns about the child's development?

What is the carers beliefs about the strengths and potential areas of improvement of the child? 
WORK AND EDUCATIONAL HISTORY OF CAREGIVER

Highest level of education

Employed Unemployed

Receiving D / G

Pension

Other

Job description

Employers Name

ACCOMMODATION / SOCIAL SITUATION

House

Flat

Council House

Shack

Other

Amount of people living in the house (family members and siblings?)

Support structure

General comments

TRANSPORTATION

Means of transportation

\section{GENERAL COMMENTS}

Interviewer:

Date of interview: 


\section{Appendix 0: Definitions of Test of Playfulness (ToP) items}

Definitions of ToP Items

Item Description

Is actively engaged.

Extent-Proportion of time player is involved in activities rather than aimless wandering or other nonfocused activity or temper tantrums. Intensity-Degree to which the child is concentrating on the activity or playmates.

Skill—Players' ability to stay focused or carry a play theme from activity to activity.

Decides what to do and how to do it.

Maintains level of safety sufficient to play.

Tries to overcome barriers or obstacles to persist with an activity.

Modifies activity to maintain challenge or make it more fun.

Engages in playful mischief or teasing.

Engages in activity for the sheer pleasure of it (process) rather than primarily for the end product.

Pretends (to be someone else; to do something else; that an object is something else; that something else is happening).
Extent-Proportion of time when players actively choose what they are doing. Players may decide to do what another is doing, but no one is forcing them or rewarding them for doing the activity.

Extent-Proportion of time when players feel safe enough to play. If necessary, players may alter the environment.

Intensity-Degree to which the child perseveres in order to overcome obstacles to continuing the activity.

Skill-Ease with which the child actively changes the requirements or complexity of the task in order to vary the challenge or degree of novelty.

Extent-Proportion of time when players are involved in playful teasing or minor infractions of the rules designed to make the play more fun.

Skill-The ease, cleverness, or adeptness with which players create and carry out mischief or teasing.

Extent-Proportion of time when players seem to want to do the activity simply because they enjoy it rather than to attain a particular outcome or for some extrinsic reward.

Extent-Proportion of time when there are overt indicators players are assuming different character roles, pretending to be doing something, pretending something is happening, or pretending an object or person is something else.

Skill-The degree to which the "performance" convinces the examiner. 
Definitions of ToP Items-cont'd

Item Description

Incorporates objects or other people into play in unconventional or variable ways.

Extent-Proportion of time when players (1) use objects commonly thought of as toys in ways other than those the manufacturer clearly intended, (2) incorporate objects not classically thought of as toys into the play (e.g., bugs, table legs), or (3) use one toy or object in a numbe of different ways. Creativity is a key.

Skill-The ease or cleverness with which players incorporate objects or other people in creative ways.

Negotiates with others to have needs/desires met.

Engages in social play.

Supports play of others.

Enters a group already engaged in an activity.

Initiates play with others.

Clowns or jokes.

Shares (toys, equipment, friends, ideas).

Gives readily understandable cues (facial, verbal, body) that say, "This is how you should act toward me."

Responds to others' cues.

Demonstrates positive affect during play.

Interacts with objects.

Transitions from one play activity to another with ease.
Skill-Ease and finesse with which players verbally or nonverbally ask for what they need.

Extent-Proportion of time during which player interacts with others involved in the same or similar activity.

Intensity-The depth of the player's interactions with other people during play.

Skill-The level of social play. Ranges from playing alone to being the leader.

Skill—Ease with which players support play of others (e.g., encouragement, ideas).

Skill-Ease with which player does something to become part of a group (two or more) already engaged in an activity; the action is not disruptive to what is going on.

Skill-Ease with which player initiates a new activity with another.

Extent-Proportion of time when players tell jokes or funny stories or engage in exaggerated, swaggering behavior, usually for the purpose of gaining others' attention.

Skill-The ease or cleverness with which a player clowns or jokes.

Ranges from not gaining others' attention to gaining positive reactions from others to being overtly funny.

Skill-The ease with which players allow others to use toys, personal belongings, or equipment they are using or share playmates (friends) or ideas.

Extent-Proportion of time during which players act in a way to give out clear messages about how others should interact with them.

Extent-Proportion of time during which the child acts in accord with others' play cues.

Intensity-Degree to which player's affect is positive; ranges from mild enjoyment to real exuberance.

Intensity-The degree to which players get involved with objects. Skill-The ease with which players interact with objects.

Skill-The ease with which players move from activity to activity when one has ended or is not evolving and another is available.

(Skard \& Bundy, 2008:76) 


\section{Appendix P: Test of Playfulness (ToP) Protocol Sheet}

TEST OF PLAYFULNESS (ToP) (Version 4.0-5/05)

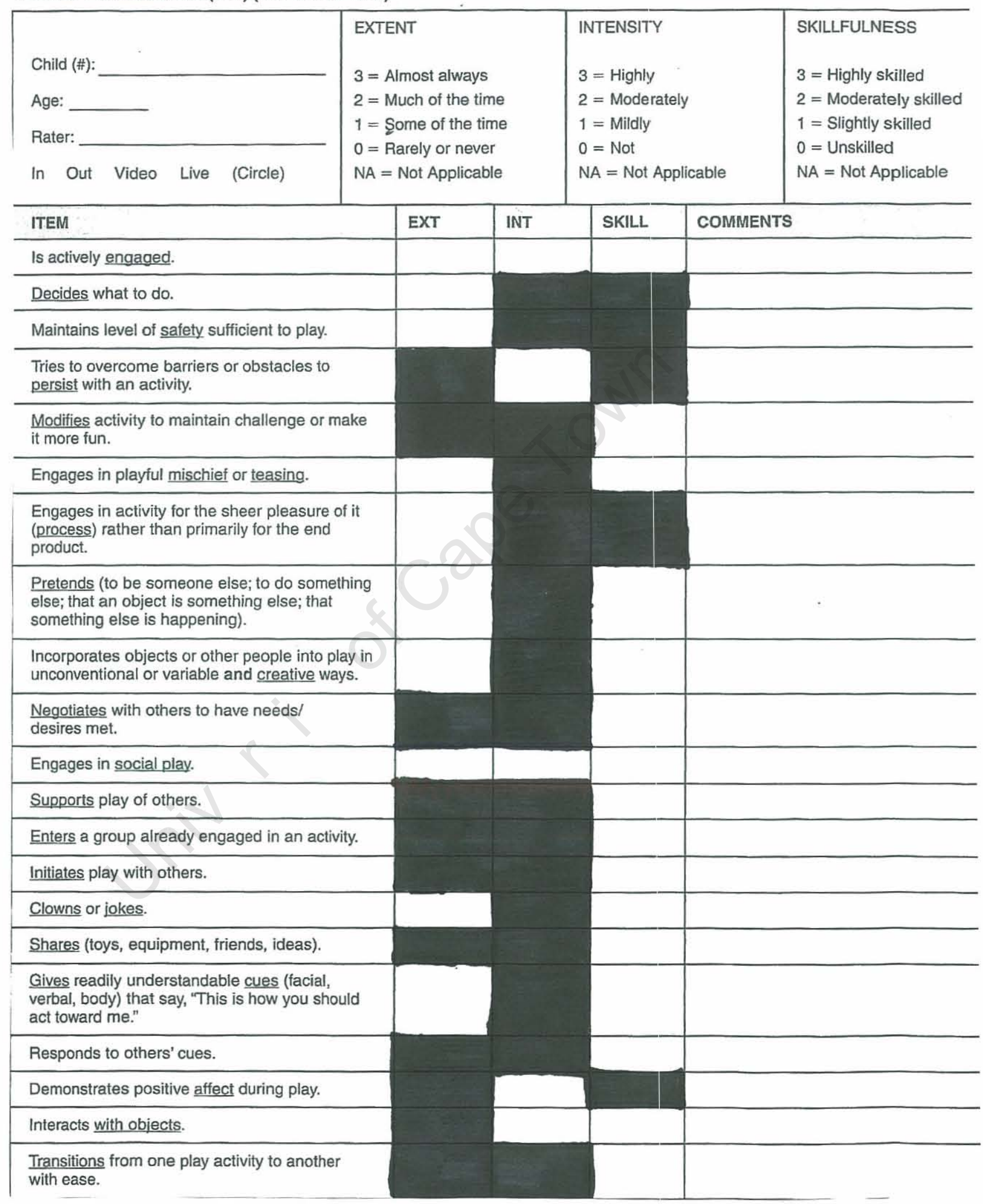

(Skard \& Bundy, 2008:78) 


\section{Appendix Q: Test of Playfulness (ToP) Keyform}
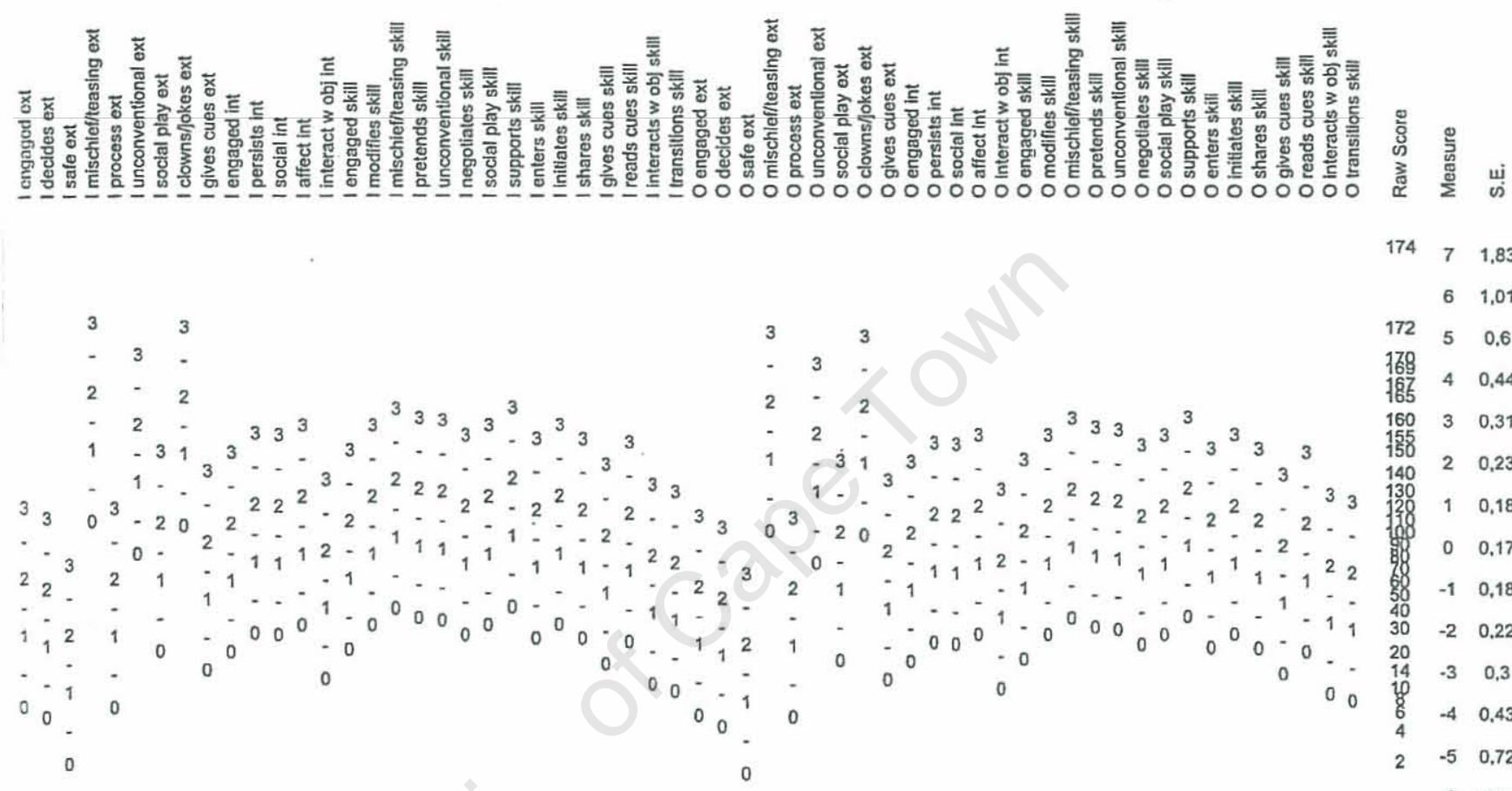


\section{Appendix R: Test of Playfulness Dataset}

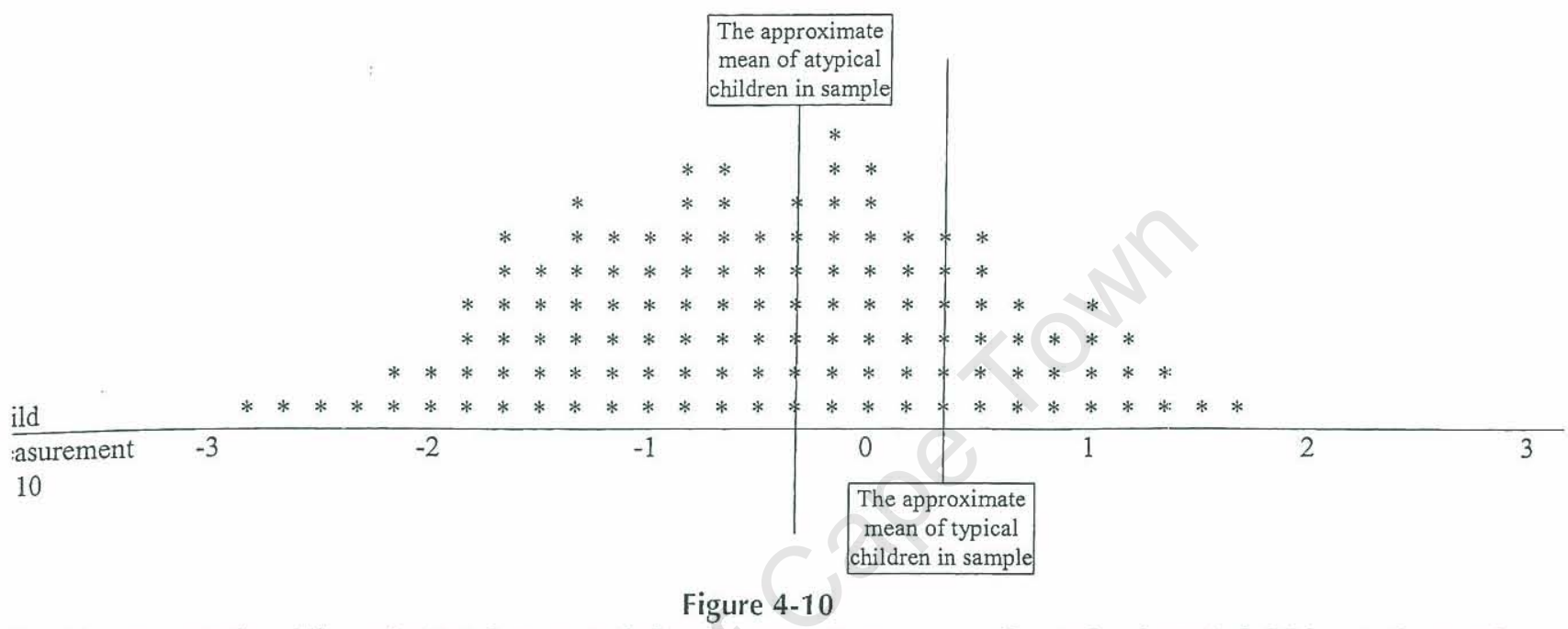

Iraphic representation of the entire ToP data set, including the approximate means of typical and atypical children in the sample.

(Skard \& Bundy, 2009:79) 


\section{Appendix S: Summary of Notes from Interviews and Playground Observations}

\section{Socio-economic Constraints}

Before filming at each one of the four schools which constituted the study sample, the researcher conducted interviews with the school psychologist, school principals, and guidance counsellors and grade one head of departments. During these interviews it came to light that the schools faced significant difficulties with the socio-economic hardships (such as extreme poverty, crime, and drug and alcohol abuse) which had come to characterise the communities in which the learners grew-up. Teachers reported that learners who came from particularly difficult home circumstances would often struggle academically, skip school and display problem behaviours such as aggression and inappropriate sexual behaviour. The National Feeding Programme (NFP) was active at all the schools in the study sample, and for some children these meals provided their only daily nutritious meal. Although teachers reported that the children's school work, energy, and concentration improved after the children had eaten the meal provided by the NFP, they reported that the fetching of the plates and eating of the meals did at times detract from lesson times and the children's break-time.

\section{Playground Facilities}

The researcher's observations of the school playgrounds were that they consisted of predominantly empty, sandy pieces of land that ran alongside the school buildings. None of the schools had any 'traditional' western playground equipment (such as jungle gyms and climbing equipment). One of the school principals reported that whenever playground equipment could be afforded and installed, it has been stolen or vandalised by members of the community. 


\section{Players}

Aside from one school where the break-times for the foundation phase (grades one to three) were separate from the break-times of the intermediate phase (grades four to six) and senior phase (grade seven), children spanning all age groups were observed to use the same playground concurrently. On a few occasions children of different age groups were be observed to play together or to converse with siblings or friends from other grades.

\section{Forms of Play Observed}

Hardly any traditional 'toys' were observed at the schools. A few of the older girls were observed to play with a skipping rope and a small number boys were observed to play with spinning tops or a ball they had brought with them from home. Some children would play spinning games in which they would form a chain by holding onto the ends of each other's jerseys and would then spin (at as fast a pace as they could muster) around the leader of the chain, often until they all fell down. However, the vast majority of the children were observed to sit in groups on the outskirts of the grounds talking or eating, while others played a rough version of 'catchers' or play fighting. 


\section{Word Count}

Total word count $=25344$

Excluding references $=17699$ 